Published in final edited form as:

Cochrane Database Syst Rev. ; (2): CD004768. doi:10.1002/14651858.CD004768.pub2.

\title{
Single dose oral diclofenac for acute postoperative pain in adults
}

\author{
Philip Derry ${ }^{2}$, Sheena Derry ${ }^{1}$, R Andrew Moore ${ }^{1}$, and Henry J McQuay ${ }^{1}$ \\ ${ }^{1}$ Pain Research and Nuffield Department of Clinical Neurosciences (Nuffield Division of \\ Anaesthetics), University of Oxford, Oxford, UK \\ ${ }^{2}$ Pain Research, University of Oxford, Oxford, UK
}

\begin{abstract}
Background-Diclofenac is a non-steroidal anti-inflammatory drug (NSAID), available as a potassium salt (immediate-release) or sodium salt (delayed-release). This review updates an earlier review published in The Cochrane Database of Systematic Reviews (Issue 2, 2004) on 'Single dose oral diclofenac for postoperative pain'.
\end{abstract}

Objectives-To assess single dose oral diclofenac for the treatment of acute postoperative pain.

Search methods-Cochrane CENTRAL, MEDLINE, EMBASE, Biological Abstracts, the Oxford Pain Relief Database, and reference lists of articles were searched; last search December 2008.

Selection criteria-Randomised, double-blind, placebo-controlled clinical trials of single dose, oral diclofenac (sodium or potassium) for acute postoperative pain in adults.

Data collection and analysis-Two review authors independently assessed studies for inclusion and quality, and extracted data. The area under the pain relief versus time curve was used to derive the proportion of participants with at least $50 \%$ pain relief over 4 to 6 hours, using validated equations. Relative benefit (risk) and number needed to treat to benefit (NNT) were calculated. Information on adverse events, time to remedication, and participants needing additional analgesia was also collected.

Copyright @ 2011 The Cochrane Collaboration. Published by John Wiley \& Sons, Ltd

Contact address: Sheena Derry, Pain Research and Nuffield Department of Clinical Neurosciences (Nuffield Division of Anaesthetics), University of Oxford, Churchill Hospital, Oxford, Oxfordshire, OX3 7LJ, UK. sheena.derry @ pru.ox.ac.uk. Editorial group: Cochrane Pain, Palliative and Supportive Care Group.

Publication status and date: Stable (no update expected for reasons given in 'What's new'), published in Issue 11, 2011.

Review content assessed as up-to-date: 14 September 2011.

CONTRIBUTIONS OF AUTHORS For the earlier review: JB and JE were involved with searching, quality scoring, data extraction, analysis, and writing. RAM and HJM were involved with planning, quality scoring, analysis, and writing.

For the update: PD and SD were involved with searching, data extraction, quality scoring, analysis and writing. RAM was involved in analysis and writing. HJM acted as arbitrator and was involved in writing.

DECLARATIONS OF INTEREST RAM and HJM have consulted for various pharmaceutical companies. RAM and HJM have received lecture fees from pharmaceutical companies related to analgesics and other healthcare interventions. RAM, HJM and SD have received research support from charities, government and industry sources at various times. Support for this review came from Oxford Pain Research, the NHS Cochrane Collaboration Programme Grant Scheme, and NIHR Biomedical Research Centre Programme. 
Main results-Fifteen studies (eight additional studies) with 1512 participants more than doubled the information available at each dose. Overall $50 \%$ to $60 \%$ of participants experienced at least $50 \%$ pain relief over 4 to 6 hours at any dose with diclofenac, compared to 10 to $20 \%$ with placebo, giving NNTs of about 2.5 for doses of $25 \mathrm{mg}$ to $100 \mathrm{mg}$ (similar to earlier review); no dose response was demonstrated. At $50 \mathrm{mg}$ and $100 \mathrm{mg}$, NNTs for diclofenac potassium (2.1 (1.8 to 2.4 ) and 1.9 (1.7 to 2.2)) were significantly lower (better) than for diclofenac sodium (6.7 (4.2 to 17) and 4.5 (3.2 to 7.7)). The median time to use of rescue medication was 2 hours for placebo, 4.3 hours for diclofenac $50 \mathrm{mg}$ and 4.9 hours for diclofenac $100 \mathrm{mg}$. Adverse events were reported at a similar rate to placebo, with no serious events.

Authors' conclusions-Oral diclofenac is an effective single-dose treatment for moderate to severe postoperative pain. Significantly more participants experienced at least $50 \%$ pain relief over 4 to 6 hours with diclofenac potassium than with diclofenac sodium. There was no significant difference between diclofenac and placebo in the incidence of adverse events.

\section{Medical Subject Headings (MeSH)}

Acute Disease; Administration, Oral; Anti-Inflammatory Agents, Non-Steroidal [*administration \& dosage; adverse effects]; Chemistry, Pharmaceutical; Cyclooxygenase Inhibitors [administration \& dosage; adverse effects]; Diclofenac [*administration \& dosage; adverse effects]; Pain, Postoperative [*drug therapy]; Randomized Controlled Trials as Topic

\section{MeSH check words}

Adult; Humans

\section{BACKGROUND}

This review is an update of a previously published review in The Cochrane Database of Systematic Reviews (Issue 2, 2004) on 'Single dose oral diclofenac for postoperative pain' (Barden 2004a), which itself was an update of two earlier non-Cochrane reviews (Collins 1998; Collins 1999). The title now states that the review is limited to adults.

Acute pain occurs as a result of tissue damage either accidentally due to an injury or as a result of surgery. Acute postoperative pain is a manifestation of inflammation due to tissue injury. The management of postoperative pain and inflammation is a critical component of patient care. The aim of this series of reviews is to present evidence for relative analgesic efficacy through indirect comparisons with placebo, in very similar trials performed in a standard manner, with very similar outcomes, and over the same duration. Such relative analgesic efficacy does not in itself determine choice of drug for any situation or patient, but guides policy-making at the local level.

Recent reviews include lumiracoxib (Roy 2007) and celecoxib (Derry 2008), and will include updates of existing reviews like aspirin (Oldman 2000).

Single dose trials in acute pain are commonly short in duration, rarely lasting longer than 12 hours. The numbers of participants is small, allowing no reliable conclusions to be drawn about safety. To show that the analgesic is working it is necessary to use placebo (McQuay 
2005). There are clear ethical considerations in doing this. These ethical considerations are answered by using acute pain situations where the pain is expected to go away, and by providing additional analgesia, commonly called rescue analgesia, if the pain has not diminished after about an hour. This is reasonable, because not all participants given an analgesic will have significant pain relief. Approximately $18 \%$ of participants given placebo will have significant pain relief (Moore 2005), and up to 50\% may have inadequate analgesia with active medicines. The use of additional or rescue analgesia is hence important for all participants in the trials.

Clinical trials measuring the efficacy of analgesics in acute pain have been standardised over many years. Trials have to be randomised and double blind. Typically, in the first few hours or days after an operation, patients develop pain that is moderate to severe in intensity, and will then be given the test analgesic or placebo. Pain is measured using standard pain intensity scales immediately before the intervention, and then using pain intensity and pain relief scales over the following 4 to 6 hours for shorter acting drugs, and up to 12 or 24 hours for longer acting drugs. Pain relief of half the maximum possible pain relief or better (at least $50 \%$ pain relief) is typically regarded as a clinically useful outcome. For patients given rescue medication it is usual for no additional pain measurements to be made, and for all subsequent measures to be recorded as initial pain intensity or baseline (zero) pain relief (baseline observation carried forward). This process ensures that analgesia from the rescue medication is not wrongly ascribed to the test intervention. In some trials the last observation is carried forward, which gives an inflated response for the test intervention compared to placebo, but the effect has been shown to be negligible over 4 to 6 hours (Moore 2005). Patients usually remain in the hospital or clinic for at least the first six hours following the intervention, with measurements supervised, although they may then be allowed home to make their own measurements in trials of longer duration.

Clinicians prescribe non-steroidal anti-inflammatory drugs (NSAIDs) on a routine basis for a range of mild-to-moderate pain. NSAIDs are the most commonly prescribed analgesic medications worldwide, and their efficacy for treating acute pain has been well demonstrated (Moore 2003). They reversibly inhibit cyclooxygenase (prostaglandin endoperoxide synthase), the enzyme mediating production of prostaglandins and thromboxane A2 (Fitzgerald 2001). Prostaglandins mediate a variety of physiological functions such as maintenance of the gastric mucosal barrier, regulation of renal blood flow, and regulation of endothelial tone. They also play an important role in inflammatory and nociceptive processes. However, relatively little is known about the mechanism of action of this class of compounds aside from their ability to inhibit cyclooxygenase-dependent prostanoid formation (Hawkey 1999). Since NSAIDs do not depress respiration and do not impair gastrointestinal motility as do opioids (BNF 2002) they are clinically useful for treating pain after minor surgery and day surgery, and have an opiate-sparing effect after more major surgery (Grahame-Smith 2002).

Diclofenac is a benzene acetic acid derivative used to treat the pain and swelling associated with rheumatic disorders since 1974 (Fineschi 1997), and is one of the most widely used NSAIDs in the world, especially outside the USA. Almost eight million prescriptions for diclofenac were dispensed in England in 2007 (PACT 2007), the most common doses being 
$75 \mathrm{mg}$ and $150 \mathrm{mg}$ given daily in divided doses. It is available in two different formulations, diclofenac potassium and diclofenac sodium, with the sodium salt used much more frequently ( 7.9 of the eight million prescriptions in England in 2007). Diclofenac potassium is formulated to be released and absorbed in the stomach. Diclofenac sodium, usually distributed in enteric-coated tablets, resists dissolution in low PH gastric environments, releasing instead in the duodenum (Olson 1997). The potassium and sodium formulations present different hypothetical advantages; the immediate-release potassium formulation might provide pain relief more quickly (Bakshi 1992), whereas the delayed-release formulation might minimise gastric exposure theoretically minimising the risk of adverse gastrointestinal events (this is unlikely as NSAID-related gastrointestinal adverse effects are more closely linked with systemic (overall) concentration). The clinical bearing of these differences has yet to be established.

A major concern regarding the use of conventional NSAIDs postoperatively is the possibility of bleeding from both the operative site (because of the inhibition of platelet aggregation) (Forrest 2002) and from the upper gastrointestinal tract, (especially in patients stressed by surgery, the elderly, frail, or dehydrated). Other potentially serious adverse events include acute liver injury, acute renal injury, heart failure, and adverse reproductive outcomes (Hernández-Díaz 2001). Research has also implicated diclofenac in haematological abnormalities (Martindale 1996). However, such complications are more likely to occur with chronic use and NSAIDs generally present fewer risks if used in the short term, as in the treatment of postoperative pain (Rapoport 1999).

The previous review included seven studies in which 581 participants were treated with diclofenac and 364 with placebo. For doses of $25 \mathrm{mg}$ to $100 \mathrm{mg}$, two to three participants needed to be treated for one to achieve at least $50 \%$ pain relief who would not have done so with placebo. The median time to use of rescue medication was 7.2 hours with diclofenac $100 \mathrm{mg}$, compared to 2.0 hours for placebo. There was no significant difference in numbers of participants experiencing any adverse event between diclofenac and placebo. Since that review, a number of new studies have been published, which should permit calculation of more robust estimates of both efficacy and harm.

\section{OBJECTIVES}

To evaluate the analgesic efficacy and safety of oral diclofenac in the treatment of acute postoperative pain, using methods that permit comparison with other analgesics evaluated in the same way, using criteria of efficacy recommended by an in-depth study at the individual patient level (Moore 2005).

\section{METHODS}

\section{Criteria for considering studies for this review}

Types of studies-Studies were included if they were full publications of double blind trials of a single dose oral diclofenac against placebo for the treatment of moderate to severe postoperative pain in adults, with at least ten participants randomly allocated to each treatment group. Multiple dose studies were included if appropriate data from the first dose 
were available, and cross-over studies were included provided that data from the first arm were presented separately.

Studies were excluded if they were:

- posters or abstracts not followed up by full publication;

- $\quad$ reports of trials concerned with pain other than postoperative pain (including experimental pain);

- $\quad$ studies using healthy volunteers;

- $\quad$ studies where pain relief was assessed by clinicians, nurses or carers (i.e., not patient-reported);

- $\quad$ studies of less than 4 hours' duration or which failed to present data over 4 to 6 hours post-dose.

Types of participants - Studies of adult participants (15 years old or above) with established moderate to severe postoperative pain were included. For studies using a visual analogue scale (VAS), pain of at least moderate intensity was assumed when the VAS score was greater than $30 \mathrm{~mm}$ (Collins 1997). Studies of participants with postpartum pain were included provided the pain investigated resulted from episiotomy or Caesarean section (with or without uterine cramp). Studies investigating participants with pain due to uterine cramps alone were excluded.

Types of interventions-Orally administered diclofenac sodium or potassium with matched placebo administered as a single oral dose for post-operative pain.

Types of outcome measures-Data collected included the following:

- characteristics of participants;

- $\quad$ pain model;

- $\quad$ patient-reported pain at baseline (physician, nurse, or carer reported pain will not be included in the analysis);

- patient-reported pain relief and/or pain intensity expressed hourly over 4 to 6 hours using validated pain scales (pain intensity and pain relief in the form of VAS or categorical scales, or both), or reported total pain relief (TOTPAR) or summed pain intensity difference (SPID) at 4 to 6 hours;

- patient-reported global assessment of treatment (PGE), using a standard five-point scale;

- number of participants using rescue medication, and the time of assessment;

- time to use of rescue medication;

- withdrawals - all cause, adverse event;

- adverse events - participants experiencing one or more, and any serious adverse event, and the time of assessment. 


\section{Search methods for identification of studies}

For the earlier review the following electronic databases were searched using a sensitive search strategy:

- $\quad$ The Cochrane Library (Issue 3, 2001).

- The Specialised Register of the Cochrane Pain, Palliative and Supportive Care group (November 2002).

- MEDLINE (1966 to May 1996).

- EMBASE (1980 to 1996).

- Biological Abstracts (1985 to 1996).

- PubMed (August 2001).

- Oxford Pain database (Jadad 1996a).

For this update the following electronic databases were searched:

- Cochrane CENTRAL (Issue 4, 2008).

- MEDLINE via Ovid (1996 to December 2008).

- EMBASE via Ovid (1996 to December 2008).

See Appendix 1 for the MEDLINE search strategy, Appendix 2 for the EMBASE search strategy and Appendix 3 for the CENTRAL search strategy.

Additional studies were sought in reference lists of retrieved articles and reviews.

Language-No language restriction was applied.

Unpublished studies-Abstracts, conference proceedings and other grey literature were not searched. Merck provided details of two unpublished studies for the original review, but manufacturers were not contacted for this update.

\section{Data collection and analysis}

Selection of studies-Two review authors independently assessed and agreed the search results for studies that might be included in the updated review. Disagreements were resolved by consensus or referral to a third review author.

Quality assessment-Two review authors independently assessed the included studies for quality using a five-point scale (Jadad 1996b).

The scale used is as follows:

- Is the study randomised? If yes give one point.

- Is the randomisation procedure reported and is it appropriate? If yes add one point, if no deduct one point.

- Is the study double blind? If yes then add one point. 
- Is the double blind method reported and is it appropriate? If yes add 1 point, if no deduct one point.

- Are the reasons for patient withdrawals and dropouts described? If yes add one point.

The results are described in the 'Methodological quality of included studies' section below, and 'Characteristics of included studies' table.

Data management-Data were extracted by two review authors and recorded on a standard data extraction form. Data suitable for pooling were entered into RevMan 5.0.16.

Data analysis-QUOROM guidelines were followed (Moher 1999). For efficacy analyses we used the number of participants in each treatment group who were randomised, received medication, and provided at least one post-baseline assessment. For safety analyses we used number of participants who received study medication in each treatment group. Analyses were planned for different doses. Sensitivity analyses were planned for pain model (dental versus other postoperative pain), trial size (39 or fewer versus 40 or more per treatment arm), and quality score (two versus three or more), salt preparation (Na versus $\mathrm{K}$ salt), and formulation (tablet versus dispersible). A minimum of two studies and 200 participants were required for any analysis (Moore 1998).

\section{Primary outcome}

Number of participants achieving at least $50 \%$ pain relief: For each study, mean TOTPAR (total pain relief) or SPID (summed pain intensity difference) for active and placebo groups were converted to \%maxTOTPAR or \% maxSPID by division into the calculated maximum value (Cooper 1991). The proportion of participants in each treatment group who achieved at least 50\%maxTOTPAR was calculated using verified equations (Moore 1996; Moore 1997a; Moore 1997b). These proportions were then converted into the number of participants achieving at least 50\% maxTOTPAR by multiplying by the total number of participants in the treatment group. Information on the number of participants with at least 50\% maxTOTPAR for active treatment and placebo was then used to calculate relative benefit (RB) and number needed to treat to benefit (NNT).

Pain measures accepted for the calculation of TOTPAR or SPID were:

- five-point categorical pain relief (PR) scales with comparable wording to "none, slight, moderate, good or complete";

- four-point categorical pain intensity (PI) scales with comparable wording to "none, mild, moderate, severe";

- VAS for pain relief;

- VAS for pain intensity.

If none of these measures were available, numbers of participants reporting "very good or excellent" on a five-point categorical global scale with the wording "poor, fair, good, very 
good, excellent" were taken as those achieving at least 50\% pain relief (Collins 2001). Further details of the scales and derived outcomes are in the glossary (Appendix 4).

\section{Secondary outcomes}

1. Use of rescue medication: Numbers of participants requiring rescue medication were used to calculate relative risk and numbers needed to treat to prevent (NNTp) use of rescue medication for treatment and placebo groups. Median (or mean) time to use of rescue medication was used to calculate the weighted mean of the median (or mean) for the outcome. Weighting was by number of participants.

2. Adverse events: Numbers of participants reporting adverse events for each treatment group were used to calculate relative risk and numbers needed to treat to harm $(\mathrm{NNH})$ estimates for:

i. any adverse event;

ii. any serious adverse event (as reported in the study);

iii. withdrawal due to an adverse event.

3. Withdrawals: Withdrawals for reasons other than lack of efficacy (participants using rescue medication - see above) and adverse events were noted, as were exclusions from analysis where data were presented.

Relative benefit or risk estimates were calculated with $95 \%$ confidence intervals (CI) using a fixed-effect model (Morris 1995). NNT, NNTp and NNH with 95\% CI were calculated using the pooled number of events by the method of Cook and Sackett (Cook 1995). A statistically significant difference from control was assumed when the $95 \%$ CI of the relative benefit did not include the number one.

Homogeneity of studies was assessed visually (L'Abbé 1987). The z test (Tramèr 1997) was used to determine if there was a significant difference between NNTs for different doses of active treatment, or between groups in the sensitivity analyses.

\section{RESULTS}

\section{Description of studies}

See: Characteristics of included studies; Characteristics of excluded studies.

The earlier review included seven studies (Ahlstrom 1993; Bakshi 1992; Bakshi 1994; Herbertson 1995; Mehlisch 1995; Nelson 1994; Olson 1997). The new searches identified an additional nine potentially relevant studies. One (Tam 2001) was excluded after reading the full paper, and eight were included (Chang 2002; Cooper 1996; Desjardins 2004; Hersh 2004; Hofele 2006; Kubitzek 2003; Torres 2004; Zuniga 2004). In total 15 studies were included in this review update. Details are in the relevant 'Characteristics of studies' tables.

In the 15 included studies, a total of 1512 participants were treated with diclofenac and 793 with placebo. 
Diclofenac 25 mg was used in four studies (Hersh 2004; Kubitzek 2003; Nelson 1994; Olson 1997), diclofenac $50 \mathrm{mg}$ in 11 studies (13 treatment arms) (Ahlstrom 1993; Bakshi 1992; Bakshi 1994; Chang 2002; Cooper 1996; Herbertson 1995; Hersh 2004; Hofele 2006; Mehlisch 1995; Nelson 1994; Olson 1997), diclofenac 75 mg in one study (Torres 2004), and diclofenac $100 \mathrm{mg}$ in seven studies (eight treatment arms) (Desjardins 2004; Herbertson 1995; Hersh 2004; Mehlisch 1995; Nelson 1994; Olson 1997;Zuniga 2004).

Thirteen studies used diclofenac tablets (Bakshi 1992; Bakshi 1994; Chang 2002; Cooper 1996; Desjardins 2004; Herbertson 1995; Mehlisch 1995; Nelson 1994; Olson 1997), three used a dispersible (drinkable) preparation (Ahlstrom 1993; Bakshi 1994;Hofele 2006), and one used a softgel preparation (Zuniga 2004). Three studies used diclofenac sodium (Na) (Chang 2002; Cooper 1996; Desjardins 2004), seven used diclofenac potassium (K) (Herbertson 1995; Hersh 2004; Hofele 2006; Kubitzek 2003; Mehlisch 1995; Nelson 1994; Olson 1997), two compared the same dose of Na and K salt preparations (Bakshi 1992; Zuniga 2004), one used the free acid (Bakshi 1994) and two did not specify the salt preparation used (Ahlstrom 1993; Torres 2004).

Eleven studies were in participants with dental pain following surgical extraction of one or more impacted third molars (Ahlstrom 1993; Bakshi 1992; Bakshi 1994; Chang 2002; Cooper 1996; Hersh 2004; Hofele 2006; Kubitzek 2003; Mehlisch 1995; Nelson 1994; Zuniga 2004), and one each in participants with pain following bunionectomy (Desjardins 2004), general gynaecological surgery (Herbertson 1995), post episiotomy (Olson 1997), and inguinal hernia (Torres 2004).

Trial duration was 6 hours in seven studies (Ahlstrom 1993; Bakshi 1992; Bakshi 1994; Cooper 1996; Hersh 2004; Kubitzek 2003;Nelson 1994), eight hours in three studies (Herbertson 1995;Mehlisch 1995; Olson 1997), 24 hours in four studies (Chang 2002; Desjardins 2004; Hofele 2006; Zuniga 2004), and 36 hours in one study (Torres 2004).

\section{Risk of bias in included studies}

Methodological quality of included studies-All included studies were both randomised and double blind. Five studies were given a quality score of five (Chang 2002; Desjardins 2004; Hersh 2004; Hofele 2006; Zuniga 2004), six a score of four (Ahlstrom 1993; Bakshi 1994; Kubitzek 2003; Nelson 1994;Mehlisch 1995; Olson 1997) and four a score of three (Bakshi 1992; Cooper 1996; Herbertson 1995; Torres 2004).

Full details are in the 'Characteristics of included studies' table.

\section{Effects of interventions}

All 15 included studies provided some data for quantitative analysis. Fourteen trials contributed data to the primary efficacy outcome. One trial looking at $75 \mathrm{mg}$ dose (Torres 2004) did not report baseline pain intensity, so that SPID could not be calculated. 


\section{Number of participants achieving at least $50 \%$ pain relief (see Summary of results $A$ )}

Diclofenac $25 \mathrm{mg}$ versus placebo: Four studies with 502 participants provided data (Hersh 2004;Kubitzek 2003; Nelson 1994; Olson 1997) (please see Table 1 and Figure 1).

- The proportion of participants experiencing at least 50\% pain relief over 4 to 6 hours with diclofenac $25 \mathrm{mg}$ was 53\% (131/248; range 46\% to 62\%).

- The proportion of participants experiencing at least $50 \%$ pain relief with placebo was $15 \%(37 / 254$; range $8 \%$ to $29 \%)$.

- The relative benefit of treatment compared with placebo was 3.6 (2.6 to 5.0), giving an NNT for at least 50\% pain relief over 4 to 6 hours of 2.6 (2.2 to 3.3).

Diclofenac $50 \mathrm{mg}$ versus placebo: Eleven studies (13 treatment arms) with 1325 participants provided data (Ahlstrom 1993; Bakshi 1992; Bakshi 1994; Chang 2002; Cooper 1996; Herbertson 1995; Hersh 2004; Hofele 2006; Mehlisch 1995; Nelson 1994; Olson 1997) (please see Table 1 and Figure 2).

- The proportion of participants experiencing at least $50 \%$ pain relief over 4 to 6 hours with diclofenac $50 \mathrm{mg}$ was 57\% (441/780; range 26\% to $75 \%$ ).

- The proportion of participants experiencing at least 50\% pain relief with placebo was $19 \%(102 / 545$; range $5 \%$ to $30 \%)$.

- The relative benefit of treatment compared with placebo was 3.0 (2.5 to 3.6), giving an NNT for at least 50\% pain relief over 4 to 6 hours of 2.7 (2.4 to 3.0).

Diclofenac $100 \mathrm{mg}$ versus placebo: Seven studies (eight treatment arms) with 787 participants provided data (Desjardins 2004; Herbertson 1995; Hersh 2004; Mehlisch 1995; Nelson 1994; Olson 1997; Zuniga 2004) (please see Table 1 and Figure 3).

- The proportion of participants experiencing at least $50 \%$ pain relief over 4 to 6 hours with diclofenac $100 \mathrm{mg}$ was 56\% (231/416; range 15\% to $79 \%$ ).

- The proportion of participants experiencing at least 50\% pain relief with placebo was $12 \%(44 / 371$; range $5 \%$ to $29 \%)$.

- The relative benefit of treatment compared with placebo was 4.8 (3.6 to 6.4), giving an NNT for at least 50\% pain relief over 4 to 6 hours of 2.3 (2.0 to 2.5).

\section{Summary of results $A$}

Number of participants with $\geq 50 \%$ pain relief over 4 to 6 hours

\begin{tabular}{llllll}
\hline Dose & Studies & Participants & Diclofenac (\%) & Placebo (\%) & NNT (95\% CI) \\
\hline $25 \mathrm{mg}$ & 4 & 502 & 53 & 15 & $2.6(2.2$ to 3.3$)$ \\
\hline $50 \mathrm{mg}$ & 11 & 1325 & 57 & 19 & $2.7(2.4$ to 3.0$)$ \\
\hline $100 \mathrm{mg}$ & 7 & 787 & 56 & 12 & $2.3(2.0$ to 2.6$)$ \\
\hline
\end{tabular}




\section{Sensitivity analysis of primary outcome (see Summary of results B)}

Methodological quality: All studies scored three or more for methodological quality, so no sensitivity analysis was carried out for this criterion.

\section{Pain model; dental versus other surgery}

Diclofenac 50 mg: (Please see Figure 4)

Nine studies reporting the primary outcome were in dental pain (Ahlstrom 1993; Bakshi 1992; Bakshi 1994; Chang 2002; Cooper 1996; Hersh 2004; Hofele 2006; Mehlisch 1995; Nelson 1994). The proportion of participants with at least $50 \%$ pain relief was $56 \%$ (378/678) for diclofenac $50 \mathrm{mg}$, and 19\% (82/441) for placebo. The relative benefit was 3.0 (2.4 to 3.7), and the NNT was 2.7 (2.4 to 3.1 ).

Two studies reporting the primary outcome were in other types of surgery (Herbertson 1995; Olson 1997). The proportion of participants with at least 50\% pain relief was $62 \%(63 / 102)$ for diclofenac $50 \mathrm{mg}$, and 19\% (20/104) for placebo. The relative benefit was 3.2 (2.1 to 4.9), and the NNT was 2.4 (1.8 to 3.3). The $95 \%$ CI for dental and other surgery overlap, indicating that there was no significant difference for this outcome between dental and other types of surgery in these studies.

Diclofenac 100 mg: (Please see Figure 5)

Four studies reporting the primary outcome were in dental pain (Hersh 2004; Mehlisch 1995; Nelson 1994; Zuniga 2004). The proportion of participants with at least 50\% pain relief was $66 \%$ (151/228) for diclofenac $100 \mathrm{mg}$, and 10\% (19/185) for placebo. The relative benefit was 6.6 (4.3 to 10), and the NNT was 1.8 (1.6 to 2.1).

Three studies reporting the primary outcome were in other types of surgery (Desjardins 2004; Herbertson 1995; Olson 1997). The proportion of participants with at least 50\% pain relief was 42\% (79/188) for diclofenac $100 \mathrm{mg}$, and 13\% (24/186) for placebo. The relative benefit was 3.3 (2.2 to 4.9 ), and the NNT was 3.4 (2.7 to 4.9 ).

There was a statistically significant difference for this outcome between dental and other surgery in these studies $(\mathrm{z}=4.6, \mathrm{P}<0.0001)$

There was insufficient data to analyse the $25 \mathrm{mg}$ dose separately.

\section{Salt preparation: sodium ( $\mathrm{Na})$ versus potassium $(\mathrm{K})$}

Diclofenac 50 mg: (Please see Figure 6)

Three studies reporting the primary outcome used diclofenac Na (Bakshi 1992; Chang 2002; Cooper 1996). The proportion of participants with at least 50\% pain relief was 30\% (58/193) for diclofenac Na $50 \mathrm{mg}$, and 15\% (18/120) for placebo. The relative benefit was 2.0 (1.3 to 3.3), and the NNT was 6.7 (4.2 to 17).

Seven studies reporting the primary outcome used diclofenac K (Bakshi 1992; Herbertson 1995; Hersh 2004; Hofele 2006; Mehlisch 1995; Nelson 1994; Olson 1997). The proportion 
of participants with at least 50\% pain relief was 64\% (300/469) for diclofenac K $50 \mathrm{mg}$, and $17 \%$ (60/359) for placebo. The relative benefit was 3.6 (2.8 to 4.6), and the NNT was 2.1

(1.9 to 2.4$)$.

All the studies using diclofenac Na were in dental surgery. For the five studies using diclofenac K $50 \mathrm{mg}$ in dental surgery, the proportion with at least 50\% pain relief was $65 \%$ (237/367) for diclofenac and 16\% (40/255) for placebo. The relative benefit was 3.8 (2.8 to 5.0), and the NNT was 2.1 (1.9 to 2.4). There was a statistically significant difference between the two salt preparations for this outcome $(\mathrm{z}=5.90, \mathrm{P}<0.0001)$.

Diclofenac 100 mg: (Please see Figure 7)

Two studies reporting the primary outcome used diclofenac Na (Desjardins 2004; Zuniga 2004). The proportion of participants with at least $50 \%$ pain relief was $26 \%(30 / 114)$ for diclofenac $\mathrm{Na} 100 \mathrm{mg}$, and 4\% (4/97) for placebo. The relative benefit was 5.3 (1.9 to 15), and the NNT was 4.5 (3.2 to 7.6 ).

Six studies reporting the primary outcome used diclofenac K (Herbertson 1995; Hersh 2004; Mehlisch 1995; Nelson 1994;Olson 1997; Zuniga 2004). The proportion of participants with at least 50\% pain relief was 66\% (200/302) for diclofenac K $100 \mathrm{mg}$, and 13\% (39/289) for placebo. The relative benefit was 5.0 (3.7 to 6.8 ), and the NNT was 1.9 (1.7 to 2.2).

The $95 \%$ CIs for the two salt preparations at $100 \mathrm{mg}$ do not overlap, suggesting a statistically significant difference between them for this outcome, but there were insufficient data for diclofenac $\mathrm{Na} 100 \mathrm{mg}$ to permit comparison in dental studies only.

There were insufficient data to analyse the $25 \mathrm{mg}$ dose separately.

Formulation: tablet versus dispersible: There were insufficient data for dispersible preparations to carry out this sensitivity analysis.

Study size: 40 or more participants per treatment arm versus fewer than 40: Only three studies, one at each dose (Ahlstrom 1993; Cooper 1996; Zuniga 2004) had fewer than 40 participants in each treatment arm. There were insufficient data to carry out this sensitivity analysis.

\section{Summary of results $B$}

Sensitivity analyses using number of participants with $\geq 50 \%$ pain relief over 4 to 6 hours

\begin{tabular}{llllll}
\hline Criterion & Studies & Participants & Diclofenac (\%) & Placebo (\%) & NNT (95\% CI) \\
\hline Dental surgery 50 mg & 9 & 1119 & 56 & 19 & 2.7 (2.4 to 3.1) \\
\hline Other surgery 50 mg & 2 & 206 & 62 & 19 & $2.4(1.8$ to 3.3) \\
\hline Dental surgery $100 \mathrm{mg}$ & 4 & 413 & 66 & 10 & $1.8(1.6$ to 2.1) \\
\hline Other surgery $100 \mathrm{mg}$ & 3 & 374 & 42 & 13 & $3.4(2.7$ to 4.9) \\
\hline Na salt 50 mg dental surgery & 3 & 313 & 30 & 15 & 6.7 (4.2 to 17) \\
\hline K salt 50 mg dental surgery & 5 & 622 & 65 & 16 & 2.1 (1.8 to 2.4) \\
\hline
\end{tabular}




\begin{tabular}{llllll}
\hline Criterion & Studies & Participants & Diclofenac (\%) & Placebo (\%) & NNT (95\% CI) \\
\hline Na salt $100 \mathrm{mg}$ & 2 & 211 & 26 & 4 & 4.5 (3.2 to 7.7) \\
\hline K salt $100 \mathrm{mg}$ & 6 & 591 & 66 & 13 & 1.9 (1.7 to 2.2) \\
\hline
\end{tabular}

\section{Use of rescue medication}

Proportion of participants using rescue medication (see Summary of results C): All but two studies (Cooper 1996; Desjardins 2004) reported the number or proportion of participants using rescue medication (please see Table 1 and Figure 8).

- Four studies using diclofenac $25 \mathrm{mg}$ reported the number or proportion of participants using rescue medication, all at 6 hours (Hersh 2004; Kubitzek 2003; Nelson 1994; Olson 1997). The weighted mean proportion was $51 \%$ (127/249) with diclofenac and $71 \%$ (181/255) with placebo, giving an NNTp of 5.0 (3.5 to 8.6).

- Ten studies (12 treatment arms) using diclofenac $50 \mathrm{mg}$ reported the number or proportion of participants using rescue medication, 8 to 6 hours (Ahlstrom 1993; Bakshi 1992; Bakshi 1994; Herbertson 1995; Hersh 2004; Mehlisch 1995; Nelson 1994; Olson 1997), and 2 to 8 hours (Chang 2002; Hofele 2006). The weighted mean proportion was 40\% (305/763) with diclofenac and 70\% (372/535) with placebo, giving an NNTp of 3.4 (2.9 to 4.1) for 6 to 8 hours. For 6 hours only the proportion was 35\% (172/497) with diclofenac and 68\% (296/433) with placebo, giving an NNTp of 3.0 (2.5 to 3.6) for 6 hours.

- Six studies (seven treatment arms) using diclofenac $100 \mathrm{mg}$ reported the number or proportion of participants using rescue medication, all at 6 hours (Herbertson 1995; Hersh 2004;Mehlisch 1995; Nelson 1994; Olson 1997; Zuniga 2004). The weighted mean proportion was $37 \%$, and the NNTp was 2.8 (2.3 to 3.5).

\section{Summary of results $\mathbf{C}$}

Weighted mean proportion using rescue medication

\begin{tabular}{llllll}
\hline Dose and time of assessment & Studies & Participants & Diclofenac (\%) & Placebo (\%) & NNTp (95\% CI) \\
\hline $25 \mathrm{mg}, 6$ hours only & 4 & 504 & 51 & 71 & 5.0 (3.5 to 8.6) \\
\hline $50 \mathrm{mg}, 6$ and 8 hours & 9 & 1298 & 40 & 70 & $3.4(2.9$ to 4.1$)$ \\
\hline $50 \mathrm{mg}, 6$ hours only & 5 & 930 & 35 & 68 & $3.0(2.5$ to 3.6) \\
\hline $100 \mathrm{mg}, 6$ hours only & 6 & 637 & 37 & 73 & $2.8(2.3$ to 3.5) \\
\hline
\end{tabular}

Time to use of rescue medication (see Summary of results D): Eight studies reported the median time, and three the mean time to use of rescue medication (please see Table 1).

- In four studies (502 participants) (Hersh 2004; Kubitzek 2003; Nelson 1994; Olson 1997) the weighted mean of the median time to use of rescue medication was 3.8 hours for diclofenac $25 \mathrm{mg}$ and 1.5 hours for placebo. 
- In five studies (457 participants) (Chang 2002; Hersh 2004; Mehlisch 1995; Nelson 1994; Olson 1997) the weighted mean of the median time to use of rescue medication was 4.3 hours for diclofenac $50 \mathrm{mg}$ and 2.0 hours for placebo.

- In six studies (683 participants) (Desjardins 2004; Hersh 2004; Mehlisch 1995; Nelson 1994; Olson 1997; Zuniga 2004) the weighted mean of the median time to use of rescue medication was 4.9 hours for diclofenac $100 \mathrm{mg}$ and 1.9 hours for placebo.

- In three studies (378 participants) (Bakshi 1994; Cooper 1996; Hofele 2006) the weighted mean of the mean time to use of rescue medication was 7.4 hours for diclofenac $50 \mathrm{mg}$ and 3.6 hours for placebo.

\section{Summary of results D}

Weighted median and mean time to use of rescue medication

\begin{tabular}{lllll}
\hline & & & \multicolumn{2}{l}{ Median time (hrs) } \\
\hline Dose & Studies & Participants & Diclofenac & Placebo \\
\hline $25 \mathrm{mg}$ & 4 & 502 & 3.8 & 1.5 \\
\hline $50 \mathrm{mg}$ & 5 & 457 & 4.3 & 2.0 \\
\hline $100 \mathrm{mg}$ & 6 & 683 & 4.9 & 1.9 \\
\hline & & & Mean time (hrs) \\
\hline $50 \mathrm{mg}$ & 3 & 378 & 7.4 & 3.6 \\
\hline
\end{tabular}

Adverse events (see Summary of results E): (Please see Table 2 and Figure 9)

\section{$\underline{\text { Any adverse event: }}$}

- Four studies using diclofenac $25 \mathrm{mg}$ reported on the number of participants with at least one adverse event (Hersh 2004; Kubitzek 2003; Nelson 1994; Olson 1997): $8 \%$ (20/248) with diclofenac, and 7\% (18/254) with placebo.

- Nine studies using diclofenac $50 \mathrm{mg}$ reported on the number of participants with at least one adverse event (Ahlstrom 1993; Bakshi 1992; Bakshi 1994; Herbertson 1995; Hersh 2004;Hofele 2006; Mehlisch 1995; Nelson 1994; Olson 1997): 6\% (41/643) with diclofenac, and 7\% (34/473) with placebo.

- Seven studies using diclofenac $100 \mathrm{mg}$ reported on the number of participants with at least one adverse event (Desjardins 2004; Herbertson 1995; Hersh 2004; Mehlisch 1995; Nelson 1994; Olson 1997; Zuniga 2004): 18\% (18/419) with diclofenac, and 17\% (64/373) with placebo.

At no dose was there any difference in the proportion of participants with diclofenac or placebo experiencing any adverse event. 


\section{Summary of results $E$}

Participants with at least one adverse event

\begin{tabular}{llllll}
\hline Dose & Studies & Participants & Naproxen $(\%)$ & Placebo $(\%)$ & NNH $(\mathbf{9 5 \%} \mathbf{C I})$ \\
\hline $25 \mathrm{mg}$ & 4 & 502 & 8 & 7 & not calculated \\
\hline $50 \mathrm{mg}$ & 9 & 1011 & 6 & 7 & not calculated \\
\hline $100 \mathrm{mg}$ & 7 & 792 & 18 & 17 & not calculated \\
\hline
\end{tabular}

Serious adverse event: No study reported any serious adverse events with single dose treatment. One study (Chang 2002) reported a serious event (asthma flare) in a participant given placebo, but it is not clear whether this occurred during the single or multiple dose phase.

Withdrawals-(Please see Table 2)

Participants who took rescue medication were classified as withdrawals due to lack of efficacy, and details are reported under "Use of rescue medication" above.

Withdrawals and exclusions were not reported consistently, particularly in older studies. Exclusions may not be of any particular consequence in single dose acute pain studies, where most exclusions result from patients not having moderate or severe pain (McQuay 1982). Withdrawals were sometimes reported without stating which treatment groups these referred to, or when withdrawals occurred, i.e., before assessment of analgesia at 4 to 6 hours, or at some other point before the end of the trial. Where details were given, withdrawals or exclusions were usually due to protocol violations or adverse events related to the surgical procedure.

Three studies reported withdrawals due to adverse events. Chang et al (Chang 2002) reported withdrawal of one placebo-treated participant due to an asthma flare (see serious adverse events).Desjardins 2004 reported withdrawal of one participant treated with diclofenac $100 \mathrm{mg}$, and three with placebo, but did not provide specific details. Herbertson 1995 reported withdrawal of eight participants in total, one of whom was treated with diclofenac $100 \mathrm{mg}$, and experienced nausea and vomiting.

\section{DISCUSSION}

This updated review includes eight additional studies and more than doubles the amount of information available for each dose of diclofenac. All the studies were of adequate methodological quality to minimise bias. The additional information did not significantly change the NNTs for at least $50 \%$ pain relief over 4 to 6 hours at any dose, but should make the estimates more robust.

In the updated review, with all doses of diclofenac and both salts together, 50 to $60 \%$ of participants achieved at least $50 \%$ pain relief over 4 to 6 hours, compared to 10 to $20 \%$ with placebo, giving NNTs of about 2.5; there was no dose response for this outcome. For every 
five participants with moderate to severe postoperative pain treated with a single dose of diclofenac, two would experience at least $50 \%$ pain relief who would not have done so with placebo.

Indirect comparisons of NNTs for at least 50\% pain relief over 4 to 6 hours in reviews of other analgesics using identical methods indicate that diclofenac $50 \mathrm{mg}$ has equivalent efficacy to naproxen 500/550 mg (2.7 (2.3 to 3.2)) (Derry 2009) and lumiracoxib (2.7 (2.2 to 3.5)) (Roy 2007), and is better than paracetamol $1000 \mathrm{mg}$ (3.6 (3.2 to 4.1)) (Toms 2008), but is worse than rofecoxib (2.2 (1.9 to 2.4) (Barden 2004b). A current listing of reviews of analgesics in the single dose postoperative pain model can be found at www.medicine.ox.ac.uk/bandolier/index.html.

Analysis of the primary outcome according to type of surgery demonstrated a statistically significant difference between dental surgery and other types of surgery for the $100 \mathrm{mg}$, but not the $50 \mathrm{mg}$ dose. There may be a clinically significant difference between them, but the result could also be due to chance since the number of events in each set of studies was fewer than 220 (151 and 79 in the diclofenac arms of the dental and the other surgery studies respectively). Additionally, the "other surgery" group was clinically heterogeneous, with participants undergoing bunionectomy and various gynaecological procedures.

Bunionectomy is a relatively new acute postoperative pain model and has rarely been included in single dose analgesic studies. Bunionectomy studies have not been included in comparisons of outcomes of different acute postoperative pain models (Barden 2004a), and it is not known whether bunionectomy studies produce similar results to other postoperative pain models. In the single bunionectomy study included here (Desjardins 2004), diclofenac $(100 \mathrm{mg})$ had the lowest event rate of all included studies, at $15 \%$, tentatively indicating that bunionectomy may be quantitatively different from other pain models.

Analysis of the primary outcome according to the diclofenac salt preparation used showed statistically significant differences between the sodium and potassium salts for both 50 and $100 \mathrm{mg}$. There was sufficient data for $50 \mathrm{mg}$ to carry out the sensitivity analysis in dental studies only, and the statistical difference remained highly significant $(\mathrm{P}<0.0001)$. This difference may be clinically important. In these studies the potassium salt performed better than the sodium salt, and the majority of studies in this review used the potassium salt. This is interesting because the sodium salt is the one normally dispensed, at least in England, where only 100,000 prescriptions out of almost eight million in 2007 were for the potassium salt. The bulk of the trial data is for the potassium salt, but the bulk of prescribing is for the sodium salt, which has measurably less effect. This is an important point for those producing guidelines and policy, especially as these effects in acute pain may have implications for chronic conditions.

There were insufficient data to investigate the effects on the primary outcome of tablet versus dispersible, or slow release versus immediate release formulations.

It has been suggested that data on use of rescue medication, whether as a proportion of participants requiring it, or the median time to use of it, might be helpful in assessing the usefulness of an analgesic, and possibly distinguishing between different doses (Moore 
2005). This review demonstrated a non-significant trend for fewer participants to need rescue medication within 6 hours with higher doses of diclofenac, with just over 10\% fewer using rescue medication with $100 \mathrm{mg}$ than with $25 \mathrm{mg}$. Additionally, the median time to use of rescue medication increased with higher doses, from 4 hours with $25 \mathrm{mg}$ to 5 hours with $100 \mathrm{mg}$. Both of these results indicate that the higher doses give more prolonged pain relief than lower doses. Longer duration of action may be advantageous in some circumstances. In a postoperative setting, where patients may feel nauseated, a longer time before remedication is needed and could be of benefit to the patient, and it may also reduce demands on time for nursing staff. Duration of action may also be a useful outcome with which to compare different analgesics. The full implications of the importance of remedication as an outcome awaits completion of other reviews, allowing examination of a substantial body of evidence.

Reporting of data for adverse events, withdrawals (other than lack of efficacy) or exclusions, and handling of missing data was not always complete, although it did appear to be better in the more recent studies. Adverse events were collected using various methods (questioning, patient diary) over different periods of time. This may have included periods after the use of rescue medication, which may cause its own adverse events. Poor reporting of adverse events in acute pain trials have been noted before (Edwards 1999). The usefulness of single dose studies for assessing adverse events is questionable, but it is non-the-less reassuring that there was no difference between naproxen (at any dose) and placebo for occurrence of any adverse event, and that serious adverse events and adverse event withdrawals were rare, and generally not thought to be related to the test drug. Long-term, multiple dose studies should be used for meaningful analysis of adverse events since, even in acute pain settings, analgesics are likely to be used in multiple doses.

Lack of information about withdrawals or exclusions may have led to an overestimate of efficacy, but the effect is probably not significant because it is as likely to be related to poor reporting as poor methods. In single dose studies most exclusions occur for protocol violations such as failing to meet baseline pain requirements, or failing to return for post treatment visits after the acute pain results are concluded. Where patients are treated with a single dose of medication and observed, often "on site" for the duration of the trial, it might be considered unnecessary to report on "withdrawals" if there were none. For missing data it has been shown that over the 4 to 6 hour period, there is no difference between baseline observation carried forward, which gives the more conservative estimate, and last observation carried forward (Moore 2005).

\section{AUTHORS' CONCLUSIONS}

\section{Implications for practice}

A single dose of diclofenac $100 \mathrm{mg}$ is an effective analgesic, providing at least 50\% pain relief to about half of the treated patients with acute, moderate to severe, postoperative pain. The NNT of 2.3 for at least $50 \%$ pain relief compares favourably with other analgesics commonly used for postoperative pain. In single dose, it is associated with a low rate of adverse events, similar to that with placebo. Lower doses may provide equivalent levels of analgesia, with a slightly shorter duration of action. Since the last version of this review, 
additional evidence has strengthened differences between sodium and potassium salt preparations; it may be that potassium salts are more appropriate for acute pain conditions, and sodium salts for chronic pain conditions. However, care should be exercised over the choice of potassium salt or sodium salt formulations, and a wider examination of evidence of different sorts will be needed in making appropriate choices.

\section{Implications for research}

The most important implication for research is to clarify the apparent difference in efficacy between the potassium and sodium salts of diclofenac. Further studies at lower doses with the more effective potassium salt could clarify whether useful analgesia could be achieved with less diclofenac, probably improving safety. It should always be the goal to use the lowest dose of a drug that provides the desired clinical effect, and lower doses are likely to be associated with fewer adverse events in clinical practice. Additional studies investigating the relative efficacy of the sodium and potassium salts are needed to determine whether the difference demonstrated in this review is true. The major implication is for better reporting of clinical trials, in avoiding average information from highly skewed distributions, in providing information about how many patients achieve a clinically useful level of pain relief, and in reporting other outcomes of clinical relevance, such as time to remedication.

\section{Acknowledgments}

Jodie Barden and Jayne Rees were authors on the earlier review.

\section{SOURCES OF SUPPORT}

Internal sources

- $\quad$ Pain Research funds, UK.

External sources

- $\quad$ NHS Cochrane Collaboration Programme Grant Scheme, UK.

- $\quad$ NIHR Biomedical Research Centre Programme, UK.

Support for RAM

\section{CHARACTERISTICS OF STUDIES}

\section{Characteristics of included studies [ordered by study ID]}

Ahlstrom 1993

\begin{tabular}{|c|c|}
\hline Methods & $\begin{array}{l}\mathrm{RCT}, \mathrm{DB} \text {, double dummy, single oral dose, } 3 \text { parallel groups } \\
\text { Medication administered when baseline pain was of moderate to severe intensity } \\
\text { Pain assessed at } 0,20,40,60 \text { mins then hourly up to } 6 \text { hours }\end{array}$ \\
\hline Participants & $\begin{array}{l}\text { Third molar extraction } \\
\mathrm{N}=97 \\
\mathrm{M}=46, \mathrm{~F}=51 \\
\text { Mean age } 25 \text { yrs }\end{array}$ \\
\hline Interventions & $\begin{array}{l}\text { Diclofenac (soluble) } 50 \mathrm{mg}, \mathrm{n}=35 \\
\text { Ibuprofen (tablets) } 400 \mathrm{mg}, \mathrm{n}=32 \\
\text { Placebo, } \mathrm{n}=30\end{array}$ \\
\hline
\end{tabular}




\begin{tabular}{ll} 
Outcomes & PI: std 100 mm VAS \\
& PR: std 100 mm VAS \\
& PGE: std 5 point scale \\
\hline \multirow{2}{*}{ Notes } & Oxford Quality Score: R1, DB2, W1 \\
& No details about rescue medication used or any restrictions on time before use was permitted \\
\hline
\end{tabular}

\section{Bakshi 1992}

\begin{tabular}{ll}
\hline Methods & RCT, DB, single dose, 3 parallel groups \\
& $\begin{array}{l}\text { Medication administered when baseline pain was of moderate to severe intensity } \\
\text { Pain assessed at } 0,15,30 \text { and } 60 \text { mins then hourly up to } 6 \text { hours }\end{array}$ \\
\hline Participants & Third molar extraction \\
& $\mathrm{N}=151$ \\
& $\mathrm{M}=70, \mathrm{~F}=81$ \\
& Mean age 26 yrs \\
\hline Interventions & Diclofenac K $50 \mathrm{mg}, \mathrm{n}=51$ \\
& Diclofenac Na (enteric coated) $50 \mathrm{mg}, \mathrm{n}=54$ \\
& Placebo, $\mathrm{n}=46$ \\
\hline Outcomes & PI: std 4 point scale \\
& PR: 4 point scale (non std) \\
& PGE: 4 point scale (non std) \\
\hline Notes & Oxford Quality Score: $\mathrm{R} 1, \mathrm{DB} 1, \mathrm{~W} 1$ \\
& Rescue medication permitted after 1 hour. No details about drug used \\
\hline
\end{tabular}

\section{Bakshi 1994}

\begin{tabular}{ll}
\hline Methods & RCT, DB, double dummy, single oral dose, 3 parallel groups \\
& Medication administered when baseline pain was of moderate to severe intensity \\
& Pain assessed at $0,20,40,60,90,120$ and 150 mins then hourly up to 6 hours \\
\hline Participants & Third molar extraction \\
& $\mathrm{N}=257$ \\
& $\mathrm{M}=151, \mathrm{~F}=94$ \\
& Mean age $27 \mathrm{yrs}$ \\
\hline Interventions & Diclofenac (soluble) $50 \mathrm{mg}, \mathrm{n}=83$ \\
& Ibuprofen $400 \mathrm{mg}, \mathrm{n}=80$ \\
& Placebo, $\mathrm{n}=82$ \\
\hline Outcomes & PI: std $100 \mathrm{~mm}$ VAS \\
& PR: std 5 point scale \\
& PGE: 4 point (non std) \\
\hline Notes & Oxford Quality Score: R1 DB2, W1 \\
& Rescue medication permitted after 1 hour. No details of drug used \\
\hline
\end{tabular}

\section{Chang 2002}

\begin{tabular}{ll}
\hline Methods & RCT, DB, double dummy, 3 parallel groups, single and multiple oral dose phases \\
& Medication administered when baseline pain was of moderate to severe intensity \\
& Pain assessed at $0,30,60,90,120$ mins, then hourly to 12 hours, then at $16,20,24$ hours
\end{tabular}




\begin{tabular}{|c|c|}
\hline Participants & $\begin{array}{l}\text { Third molar extraction } \\
\mathrm{N}=305 \\
\mathrm{M}=143, \mathrm{~F}=162 \\
\text { Mean age } 23 \text { yrs }\end{array}$ \\
\hline Interventions & $\begin{array}{l}\text { Diclofenac Na (enteric coated) } 50 \mathrm{mg}, \mathrm{n}=121 \\
\text { Rofecoxib } 50 \mathrm{mg}, \mathrm{n}=121 \\
\text { Placebo, } \mathrm{n}=63\end{array}$ \\
\hline Outcomes & $\begin{array}{l}\text { PR: std } 5 \text { point scale } \\
\text { PGE: std } 5 \text { point scale } \\
\text { Numbers of participants using rescue medication } \\
\text { Time to use of rescue medication } \\
\text { Numbers with any adverse event } \\
\text { Withdrawals }\end{array}$ \\
\hline Notes & $\begin{array}{l}\text { Oxford Quality Score: R2, DB2, W1 } \\
\text { Rescue medication permitted at any time (hydrocodone/paracetamol 5/500 mg) }\end{array}$ \\
\hline
\end{tabular}

\section{Cooper 1996}

\begin{tabular}{ll}
\hline Methods & RCT, DB, 4 parallel groups, single oral dose \\
& $\begin{array}{l}\text { Medication administered when baseline pain was of moderate to severe intensity } \\
\text { Pain assessed at } 0,15,30,60 \mathrm{mins} \text {, than hourly to } 6 \text { hours. }\end{array}$ \\
\hline Participants & Third molar extraction \\
& $\mathrm{N}=70$ \\
& $\mathrm{M}=27, \mathrm{~F}=43$ \\
& Mean age 24 yrs \\
\hline Interventions & Diclofenac Na $50 \mathrm{mg}, \mathrm{n}=18$ \\
& Misoprostol $200 \mu \mathrm{g}, \mathrm{n}=21$ \\
& Diclofenac Na + misoprostol $50 \mathrm{mg} / 200 \mu \mathrm{g}, \mathrm{n}=20$ \\
& Placebo, $\mathrm{n}=11$ \\
\hline \multirow{2}{*}{ Outcomes } & PI: std 4 point scale \\
& PR: std 5 point scale \\
& Time to use of rescue medication \\
& Numbers with serious adverse events \\
\hline Notes & Oxford Quality Score: R1, DB2, W0 \\
& Rescue medication permitted after 2 hours. No details of drug used \\
\hline
\end{tabular}

\section{Desjardins 2004}

\begin{tabular}{ll}
\hline Methods & RCT, DB, 3 parallel groups, single and multiple oral dose phases \\
& Medication administered when baseline pain was of moderate to severe intensity \\
& Pain assessed at $0,15,30,45,60,90,120$ mins, then hourly to 6 hours, and at $8,10,12,14$ and 24 \\
& hours \\
\hline Participants & First metatarsal bunionectomy \\
& $\mathrm{N}=252$ \\
& $\mathrm{M}=34, \mathrm{~F}=218$ \\
& Mean age $41 \mathrm{yrs}$ \\
\hline Interventions & Diclofenac Na $100 \mathrm{mg}, \mathrm{n}=85$ \\
& Rofecoxib $50 \mathrm{mg}, \mathrm{n}=85$ \\
& Placebo, $\mathrm{n}=82$ \\
\hline Outcomes & PI: std 4 point scale and VAS \\
& PR: std 5 point scale \\
& PGE: std 5 point scale \\
& Numbers using rescue medication \\
& Time to use of rescue medication \\
& Numbers with any adverse event and serious adverse events \\
& Withdrawals \\
\hline
\end{tabular}

Cochrane Database Syst Rev. Author manuscript; available in PMC 2014 September 15. 
Notes Oxford Quality Score: R2, DB2, W1

Rescue medication permitted after 90 mins (hydrocodone/paracetamol 7.5/500 mg)

\section{Herbertson 1995}

\begin{tabular}{|c|c|}
\hline Methods & $\begin{array}{l}\text { RCT, DB, } 4 \text { parallel groups, single oral dose } \\
\text { Medication administered when baseline pain was of moderate to severe intensity } \\
\text { Pain assessed at } 0,30 \text { and } 60 \text { mins, then hourly to } 8 \text { hours. }\end{array}$ \\
\hline Participants & $\begin{array}{l}\text { Gynaecological surgery } \\
\mathrm{N}=217 \\
\text { All } \mathrm{F} \\
\text { Mean age }=43 \mathrm{yrs}\end{array}$ \\
\hline Interventions & $\begin{array}{l}\text { Diclofenac K } 50 \mathrm{mg}, \mathrm{n}=52 \\
\text { Diclofenac K } 100 \mathrm{mg}, \mathrm{n}=52 \\
\text { Aspirin } 650 \mathrm{mg}, \mathrm{n}=53 \\
\text { Placebo, } \mathrm{n}=52\end{array}$ \\
\hline Outcomes & $\begin{array}{l}\text { PI: std } 4 \text { point scale } \\
\text { PR: std } 5 \text { point scale } \\
\text { PGE: std } 5 \text { point scale }\end{array}$ \\
\hline Notes & $\begin{array}{l}\text { Oxford Quality Score: R1, DB1, W1 } \\
\text { Rescue medication permitted after } 1 \text { hour, but } 2 \text { hours recommended. No details of drug used }\end{array}$ \\
\hline
\end{tabular}

Hersh 2004

\begin{tabular}{|c|c|}
\hline Methods & $\begin{array}{l}\text { RCT, DB, double dummy, } 4 \text { parallel groups, single oral dose } \\
\text { Medication administered when baseline pain was of moderate to severe intensity } \\
\text { Pain assessed at } 0,15,30,45,60,90,120 \text { mins, then hourly to } 6 \text { hours }\end{array}$ \\
\hline Participants & $\begin{array}{l}\text { Third molar extraction } \\
\mathrm{N}=265 \\
\mathrm{M}=111, \mathrm{~F}=154 \\
\text { Mean age } 21 \text { yrs }\end{array}$ \\
\hline Interventions & $\begin{array}{l}\text { Diclofenac K } 25 \mathrm{mg}, \mathrm{n}=63 \\
\text { Diclofenac K } 50 \mathrm{mg}, \mathrm{n}=68 \\
\text { Diclofenac K } 100 \mathrm{mg}, \mathrm{n}=66 \\
\text { Placebo, } \mathrm{n}=68\end{array}$ \\
\hline Outcomes & $\begin{array}{l}\text { PI: std } 4 \text { point scale } \\
\text { PR: std } 5 \text { point scale } \\
\text { PGE: std } 5 \text { point scale } \\
\text { Numbers using rescue medication } \\
\text { Time to use of rescue medication } \\
\text { Numbers with any adverse event } \\
\text { Withdrawals }\end{array}$ \\
\hline Notes & $\begin{array}{l}\text { Oxford Quality Score: R2, DB2, W1 } \\
\text { Rescue medication permitted after } 1 \text { hour (hydrocodone/paracetamol } 5 / 500 \mathrm{mg} \text { or oxycodone/ } \\
\text { paracetamol } 5 / 325 \mathrm{mg} \text { ) }\end{array}$ \\
\hline
\end{tabular}

Hofele 2006

\begin{tabular}{ll}
\hline Methods & RCT, DB, double dummy, 3 parallel groups, single oral dose \\
& $\begin{array}{l}\text { Medication administered when baseline pain was of moderate to severe intensity } \\
\text { Pain assessed at } 0,15,30,45,60,90,120 \text { mins, then hourly to } 6 \text { hours, and at } 8 \text { and } 24 \text { hours }\end{array}$ \\
\hline Participants & Third molar extraction
\end{tabular}

Cochrane Database Syst Rev. Author manuscript; available in PMC 2014 September 15. 


\begin{tabular}{ll} 
& $\mathrm{N}=184$ \\
& $\mathrm{M}=85, \mathrm{~F}=99$ \\
& Mean age $=27$ yrs \\
\hline Interventions & $\begin{array}{l}\text { Diclofenac K sachet } 50 \mathrm{mg}, \mathrm{n}=74 \\
\text { Diclofenac K tablet } 50 \mathrm{mg}, \mathrm{n}=71 \\
\\
\text { Placebo, } \mathrm{n}=39\end{array}$ \\
\hline Outcomes & PI: std 4 point scale \\
& PR: std 5 point scale \\
& PGE: std 5 point scale \\
& Numbers using rescue medication \\
& Time to use of rescue medication \\
& Numbers with any adverse event \\
& Withdrawals \\
\hline Notes & Oxford Quality Score: R2, DB2, W1 \\
& Rescue medication permitted after 2 hours (paracetamol $1000 \mathrm{mg})$ \\
\hline
\end{tabular}

Kubitzek 2003

\begin{tabular}{ll}
\hline Methods & RCT, DB, 3 parallel groups, single oral dose \\
& $\begin{array}{l}\text { Medication administered when baseline pain was of moderate to severe intensity } \\
\text { Pain assessed at } 0,30,60 \text { mins, then hourly to } 6 \text { hours }\end{array}$ \\
\hline Participants & Third molar extraction \\
& $\mathrm{N}=245$ \\
& $\mathrm{M}=\sim 40 \%, \mathrm{~F}=\sim 60 \%$ \\
& Age not given \\
\hline Interventions & Diclofenac K $25 \mathrm{mg}, \mathrm{n}=83$ \\
& $\begin{array}{l}\text { Paracetamol } 1000 \mathrm{mg}, \mathrm{n}=78 \\
\text { Placebo, } \mathrm{n}=84\end{array}$ \\
\hline Outcomes & PI: std 4 point scale \\
& PR: std 5 point scale \\
& PGE: std 5 point scale \\
& Numbers using rescue medication \\
& Time to use of rescue medication \\
& Numbers with any adverse event and serious adverse events \\
& Withdrawals \\
\hline Notes & Oxford Quality Score: R1, DB2, W1 \\
& Rescue medication permitted after 1 hour (ibuprofen $200 \mathrm{mg})$ \\
\hline
\end{tabular}

\section{Mehlisch 1995}

\begin{tabular}{|c|c|}
\hline Methods & $\begin{array}{l}\text { RCT, DB, double dummy, } 4 \text { parallel groups, single oral dose } \\
\text { Medication administered when baseline pain was of moderate to severe intensity } \\
\text { Pain assessed at } 0,30,60 \text { mins then hourly to } 8 \text { hours. }\end{array}$ \\
\hline Participants & $\begin{array}{l}\text { Third molar extraction } \\
\mathrm{N}=208 \\
\mathrm{M}=91, \mathrm{~F}=117 \\
\text { Mean age }=26 \text { yrs }\end{array}$ \\
\hline Interventions & $\begin{array}{l}\text { Diclofenac K } 50 \mathrm{mg}, \mathrm{n}=53 \\
\text { Diclofenac K } 100 \mathrm{mg}, \mathrm{n}=52 \\
\text { Aspirin } 650 \mathrm{mg}, \mathrm{n}=51 \\
\text { Placebo, } \mathrm{n}=52\end{array}$ \\
\hline Outcomes & $\begin{array}{l}\text { PI: std } 4 \text { point scale } \\
\text { PR: std } 5 \text { point scale } \\
\text { PGE: std } 5 \text { point scale } \\
\text { Numbers using rescue medication } \\
\text { Time to use of rescue medication }\end{array}$ \\
\hline
\end{tabular}

Cochrane Database Syst Rev. Author manuscript; available in PMC 2014 September 15. 
Numbers with any adverse event and serious adverse events Withdrawals

\begin{tabular}{ll} 
& Withdrawals \\
\hline Notes & Oxford Quality Score: R1, DB2, W1 \\
& Rescue medication permitted after 2 hours. No details of drug used \\
\hline
\end{tabular}

\section{Nelson 1994}

\begin{tabular}{|c|c|}
\hline Methods & $\begin{array}{l}\mathrm{RCT}, \mathrm{DB}, 5 \text { parallel groups, single oral dose } \\
\text { Medication administered when baseline pain was of moderate to severe intensity } \\
\text { Pain assessed at } 0,15,30,45,60,90,120 \text { mins, then hourly to } 6 \text { hours }\end{array}$ \\
\hline Participants & $\begin{array}{l}\text { Third Molar Extraction } \\
\mathrm{N}=183 \\
\mathrm{M}=126, \mathrm{~F}=129 \\
\text { Mean age } 25 \mathrm{yrs}\end{array}$ \\
\hline Interventions & $\begin{array}{l}\text { Diclofenac K } 25 \mathrm{mg}, \mathrm{n}=50 \\
\text { Diclofenac K } 50 \mathrm{mg}, \mathrm{n}=50 \\
\text { Diclofenac K } 100 \mathrm{mg}, \mathrm{n}=50 \\
\text { Aspirin } 650 \mathrm{mg}, \mathrm{n}=50 \\
\text { Placebo, } \mathrm{n}=50\end{array}$ \\
\hline Outcomes & $\begin{array}{l}\text { PI: std } 4 \text { point scale } \\
\text { PR: std } 5 \text { point scale } \\
\text { PGE: std } 5 \text { point scale } \\
\text { Numbers using rescue medication } \\
\text { Time to use of rescue medication } \\
\text { Numbers with any adverse event } \\
\text { Withdrawals due to adverse events }\end{array}$ \\
\hline Notes & $\begin{array}{l}\text { Oxford Quality Score: R1, DB2, W1 } \\
\text { Rescue medication permitted after } 1 \text { hour. No details of drug used }\end{array}$ \\
\hline
\end{tabular}

\section{Olson 1997}

\begin{tabular}{ll}
\hline Methods & RCT, DB, 5 parallel groups, single oral dose. \\
& Medication administered when baseline pain was of moderate to severe intensity \\
& Pain assessed at $0,30,60$ mins, then hourly to 8 hours. \\
\hline Participants & Post-episiotomy \\
& $\mathrm{N}=255$ \\
& All $\mathrm{F}$ \\
& Mean age 24 yrs \\
\hline Interventions & Diclofenac K $25 \mathrm{mg}, \mathrm{n}=52$ \\
& Diclofenac K $50 \mathrm{mg}, \mathrm{n}=50$ \\
& Diclofenac K $100 \mathrm{mg}, \mathrm{n}=51$ \\
& Aspirin $650 \mathrm{mg}, \mathrm{n}=50$ \\
& Placebo, $\mathrm{n}=52$ \\
\hline Outcomes & PI: std 4 point scale \\
& PR: std 5 point scale \\
& PGE: non std 4 point scale \\
& Numbers using rescue medication \\
& Time to use of rescue medication \\
& Numbers with any adverse event and serious adverse events \\
& Withdrawals \\
\hline Notes & Oxford Quality Score: R1, DB2, W1 \\
& Rescue medication permitted after 1 hour (non-study analgesic) \\
\hline
\end{tabular}

\section{Torres 2004}




\begin{tabular}{|c|c|}
\hline Methods & $\begin{array}{l}\mathrm{RCT}, \mathrm{DB}, 4 \text { parallel groups, single and multiple dose phases } \\
\text { Medication administered when baseline pain was of moderate to severe intensity } \\
\text { Pain assessed at } 0,30,45,60 \text { mins, then hourly to } 6 \text { hours, then at } 10,12,18,24,36 \text { hours }\end{array}$ \\
\hline Participants & $\begin{array}{l}\text { Inguinal hernia surgery } \\
\mathrm{N}=269 \\
\text { All M } \\
\text { Mean age } 53 \text { yrs }\end{array}$ \\
\hline Interventions & $\begin{array}{l}\text { Diclofenac SR } 75 \mathrm{mg}, \mathrm{n}=68 \\
\text { Valdecoxib } 20 \mathrm{mg}, \mathrm{n}=68 \\
\text { Valdecoxib } 40 \mathrm{mg}, \mathrm{n}=69 \\
\text { Placebo, } \mathrm{n}=67\end{array}$ \\
\hline Outcomes & $\begin{array}{l}\text { PI: std } 4 \text { point scale and VAS } \\
\text { PGE: non std } 4 \text { point scale } \\
\text { Numbers using rescue medication } \\
\text { Time to use of rescue medication } \\
\text { Numbers with any adverse event } \\
\text { Withdrawals }\end{array}$ \\
\hline Notes & $\begin{array}{l}\text { Oxford Quality Score: R1, DB1, W1 } \\
\text { Rescue medication permitted at any time (usual analgesic for hospital) }\end{array}$ \\
\hline
\end{tabular}

Zuniga 2004

\begin{tabular}{|c|c|}
\hline Methods & $\begin{array}{l}\text { R, DB, } 3 \text { parallel groups, single oral dose } \\
\text { Medication administered when baseline pain was of moderate to severe intensity } \\
\text { Pain assessed at } 0,15,30,45,60,90,120 \text { mins, then hourly to } 6 \text { hours, then at } 8 \text { and } 24 \text { hours }\end{array}$ \\
\hline Participants & $\begin{array}{l}\text { Third molar extraction } \\
\mathrm{N}=75 \\
\mathrm{M}=25, \mathrm{~F}=50 \\
\text { Mea age } 23 \text { yrs }\end{array}$ \\
\hline Interventions & $\begin{array}{l}\text { Diclofenac K } 100 \mathrm{mg}, \mathrm{n}=31 \\
\text { Diclofenac Na softgel } 100 \mathrm{mg}, \mathrm{n}=29 \\
\text { Placebo, } \mathrm{n}=15\end{array}$ \\
\hline Outcomes & $\begin{array}{l}\text { PI: std } 4 \text { point scale } \\
\text { PR: std } 5 \text { point scale } \\
\text { PGE: std } 5 \text { point scale } \\
\text { Numbers using rescue medication } \\
\text { Time to use of rescue medication } \\
\text { Numbers with any adverse event and serious adverse events } \\
\text { Withdrawals }\end{array}$ \\
\hline Notes & $\begin{array}{l}\text { Oxford Quality Score: R2, DB2, W1 } \\
\text { Rescue medication permitted at any time. No details of drug used }\end{array}$ \\
\hline
\end{tabular}

DB - double blind; F - female; M - male; N - total number in trial; $\mathrm{n}$ - number in treatment arm; PI - pain intensity; PR pain relief; PGE - patient global evaluation; std - standard; R - randomised; W - withdrawals

\section{Characteristics of excluded studies [ordered by study ID]}

\begin{tabular}{ll}
\hline Study & Reason for exclusion \\
\hline Ahlstrom 1989 & No placebo control \\
\hline Apaydin 1994 & No placebo control \\
\hline Aranda 1989 & No placebo control \\
\hline Carlos 1984 & $\begin{array}{l}\text { Could not be obtained despite attempts to contact authors, ordering through British library and help } \\
\text { from librarians at Novartis and Knoll pharmaceuticals }\end{array}$ \\
\hline
\end{tabular}




\begin{tabular}{|c|c|}
\hline Study & Reason for exclusion \\
\hline Dorfmann 1991 & $\begin{array}{l}\text { Inadequate description of method. Did not say whether the allocation was randomised, did not say } \\
\text { when interventions were administered, no mention of the level of baseline pain and did not define } \\
\text { the pain measurement used }\end{array}$ \\
\hline El-Tanany 1993 & No placebo control \\
\hline Fineschi 1997 & No placebo control \\
\hline Frezza 1985 & Unobtainable \\
\hline Garcia 1997 & Intravenous route \\
\hline Graf 2000 & Not obtainable \\
\hline Henderson 1994 & No placebo control \\
\hline Henrikson 1982 & Only presented data for the placebo arm for the first hour \\
\hline Hultin 1978 & $\begin{array}{l}\text { Cross-over study with the first dose administered exactly one hour after LA rather than when } \\
\text { patients experienced moderate to severe pain }\end{array}$ \\
\hline Iqbal 1986 & Unobtainable \\
\hline Iwabuchi 1980 & No placebo control \\
\hline Joubert 1977 & Unobtainable \\
\hline Kittala 1972 & Routine intervention administration irrespective of baseline pain intensity \\
\hline Li 1998 & No placebo control \\
\hline Matthews 1984 & Intervention administered irrespective of baseline pain intensity \\
\hline Mayer 1980 & Multiple dose study with no mention of baseline pain \\
\hline Nakanishi 1990 & No placebo control \\
\hline Rautela 1998 & Intramuscular route \\
\hline Shimura 1981 & No placebo control \\
\hline Tam 2001 & Intervention administered before procedure \\
\hline Tani 1974 & No placebo control \\
\hline Tesseroli 1986 & $\begin{array}{l}\text { At baseline, the mean VAS minus } 1.96 \times \text { SD was less than } 30 \mathrm{~mm} \text {, therefore some patients may } \\
\text { have been included with a baseline pain of less than moderate intensity }\end{array}$ \\
\hline Ujpal 1999 & No placebo control \\
\hline Vigneron 1977 & Unobtainable \\
\hline Walton 1993 & $\begin{array}{l}\text { First dose administered IM during surgery, oral doses then given postoperatively at specified time } \\
\text { points irrespective of baseline pain }\end{array}$ \\
\hline Wuolijoki 1987 & $\begin{array}{l}\text { Intervention administered pre-operatively or immediately post-operatively irrespective of baseline } \\
\text { pain intensity }\end{array}$ \\
\hline Zhang 2000 & Could not be obtained \\
\hline
\end{tabular}

\section{DATA AND ANALYSES}

\section{Comparison 1}

Diclofenac $25 \mathrm{mg}$ v placebo

\begin{tabular}{lcccc}
\hline Outcome or subgroup title & No. of studies & No. of participants & Statistical method & Effect size \\
\hline $\begin{array}{l}\text { 1 Participants with at least } \\
\text { 50\% pain relief over 4 to 6 }\end{array}$ & 4 & 502 & Risk Ratio (M-H, Fixed, & $3.63[2.64,4.98]$ \\
hours & & & $95 \%$ CI) & \\
\hline
\end{tabular}




\section{Comparison 2}

Diclofenac $50 \mathrm{mg}$ v placebo

\begin{tabular}{|c|c|c|c|c|}
\hline Outcome or subgroup title & No. of studies & No. of participants & Statistical method & Effect size \\
\hline $\begin{array}{l}1 \text { Participants with at least } \\
50 \% \text { pain relief over } 4 \text { to } 6 \\
\text { hours }\end{array}$ & 11 & 1325 & $\begin{array}{c}\text { Risk Ratio (M-H, Fixed, } \\
95 \% \text { CI) }\end{array}$ & $3.02[2.52,3.62]$ \\
\hline $\begin{array}{l}2 \text { Participants with at least } \\
50 \% \text { pain relief over } 4 \text { to } 6 \\
\text { hours, dental or other surgery }\end{array}$ & 11 & & $\begin{array}{c}\text { Risk Ratio (M-H, Fixed, } \\
95 \% \text { CI) }\end{array}$ & Subtotals only \\
\hline 2.1 Dental surgery & 9 & 1119 & $\begin{array}{l}\text { Risk Ratio (M-H, Fixed, } \\
95 \% \text { CI) }\end{array}$ & $2.98[2.43,3.65]$ \\
\hline 2.2 Other surgery & 2 & 206 & $\begin{array}{l}\text { Risk Ratio (M-H, Fixed, } \\
95 \% \text { CI) }\end{array}$ & $3.23[2.12,4.91]$ \\
\hline $\begin{array}{l}3 \text { Participants with at least } \\
50 \% \text { pain relief over } 4 \text { to } 6 \\
\text { hours, Na or K salt }\end{array}$ & 9 & & $\begin{array}{l}\text { Risk Ratio (M-H, Fixed, } \\
95 \% \mathrm{CI})\end{array}$ & Subtotals only \\
\hline 3.1 Diclofenac $\mathrm{Na}$ & 3 & 313 & $\begin{array}{c}\text { Risk Ratio (M-H, Fixed, } \\
95 \% \mathrm{CI})\end{array}$ & $2.04[1.26,3.31]$ \\
\hline 3.2 Diclofenac K & 7 & 828 & $\begin{array}{c}\text { Risk Ratio (M-H, Fixed, } \\
95 \% \mathrm{CI})\end{array}$ & $3.60[2.84,4.57]$ \\
\hline
\end{tabular}

\section{Comparison 3}

Diclofenac 100 mg v placebo

\begin{tabular}{|c|c|c|c|c|}
\hline Outcome or subgroup title & No. of studies & No. of participants & Statistical method & Effect size \\
\hline $\begin{array}{l}1 \text { Participants with at least } \\
50 \% \text { pain relief over } 4 \text { to } 6 \\
\text { hours }\end{array}$ & 7 & 787 & $\begin{array}{l}\text { Risk Ratio (M-H, Fixed, } \\
95 \% \mathrm{CI})\end{array}$ & $4.84[3.63,6.47]$ \\
\hline $\begin{array}{l}2 \text { Participants with at least } \\
50 \% \text { pain relief over } 4 \text { to } 6 \\
\text { hours, dental or other surgery }\end{array}$ & 7 & 787 & $\begin{array}{l}\text { Risk Ratio (M-H, Fixed, } \\
95 \% \mathrm{CI})\end{array}$ & $4.85[3.63,6.47]$ \\
\hline 2.1 Dental surgery & 4 & 413 & $\begin{array}{l}\text { Risk Ratio (M-H, Fixed, } \\
95 \% \mathrm{CI})\end{array}$ & $6.65[4.34,10.21]$ \\
\hline 2.2 Other surgery & 3 & 374 & $\begin{array}{l}\text { Risk Ratio (M-H, Fixed, } \\
95 \% \mathrm{CI})\end{array}$ & $3.31[2.24,4.88]$ \\
\hline $\begin{array}{l}3 \text { Participants with at least } \\
50 \% \text { pain relief over } 4 \text { to } 6 \\
\text { hours, Na or K salt }\end{array}$ & 7 & & $\begin{array}{l}\text { Risk Ratio (M-H, Fixed, } \\
95 \% \mathrm{CI})\end{array}$ & Subtotals only \\
\hline 3.1 Diclofenac $\mathrm{Na}$ & 2 & 211 & $\begin{array}{l}\text { Risk Ratio (M-H, Fixed, } \\
95 \% \mathrm{CI})\end{array}$ & $5.28[1.92,14.50]$ \\
\hline 3.2 Diclofenac K & 6 & 591 & $\begin{array}{c}\text { Risk Ratio (M-H, Fixed, } \\
95 \% \mathrm{CI})\end{array}$ & $5.02[3.71,6.78]$ \\
\hline
\end{tabular}

\section{Comparison 4}

Diclofenac versus placebo

\begin{tabular}{lcccc}
\hline $\begin{array}{l}\text { Outcome or subgroup } \\
\text { title }\end{array}$ & No. of studies & No. of participants & Statistical method & Effect size \\
\hline $\begin{array}{l}1 \text { Participants with at } \\
\text { least one adverse event }\end{array}$ & 12 & Risk Ratio (M-H, Fixed, 95\% & Subtotals only \\
\end{tabular}




\begin{tabular}{|c|c|c|c|c|}
\hline $\begin{array}{l}\text { Outcome or subgroup } \\
\text { title }\end{array}$ & No. of studies & No. of participants & Statistical method & Effect size \\
\hline mg 1.1 Diclofenac 25 & 4 & 502 & $\begin{array}{c}\text { Risk Ratio (M-H, Fixed, 95\% } \\
\text { CI) }\end{array}$ & $1.15[0.63,2.11]$ \\
\hline $\mathrm{mg} \quad 1.2$ Diclofenac 50 & 9 & 1116 & $\begin{array}{c}\text { Risk Ratio (M-H, Fixed, } 95 \% \\
\text { CI) }\end{array}$ & $1.00[0.65,1.55]$ \\
\hline $\mathrm{mg} \quad 1.3$ Diclofenac 100 & 7 & 792 & $\begin{array}{c}\text { Risk Ratio (M-H, Fixed, 95\% } \\
\text { CI) }\end{array}$ & $1.04[0.79,1.39]$ \\
\hline $\begin{array}{l}2 \text { Participants using } \\
\text { rescue medication at } 6 \\
\text { hours }\end{array}$ & 10 & & $\begin{array}{l}\text { Risk Ratio (M-H, Fixed, } 95 \% \\
\text { CI) }\end{array}$ & Subtotals only \\
\hline mg 2.1 Diclofenac 25 & 4 & 504 & $\begin{array}{l}\text { Risk Ratio (M-H, Fixed, } 95 \% \\
\text { CI) }\end{array}$ & $0.72[0.63,0.82]$ \\
\hline mg 2.2 Diclofenac 50 & 8 & 930 & $\begin{array}{c}\text { Risk Ratio (M-H, Fixed, } 95 \% \\
\text { CI) }\end{array}$ & $0.50[0.44,0.58]$ \\
\hline mg 2.3 Diclofenac 100 & 6 & 637 & $\begin{array}{c}\text { Risk Ratio (M-H, Fixed, } 95 \% \\
\text { CI) }\end{array}$ & $0.48[0.41,0.56]$ \\
\hline
\end{tabular}

\section{Analysis 1.1. Comparison 1 Diclofenac $25 \mathrm{mg}$ v placebo, Outcome 1 Participants with at least $50 \%$ pain relief over 4 to 6 hours}

Review: Single dose oral diclofenac for acute postoperative pain in adults

Comparison: 1 Diclofenac $25 \mathrm{mg}$ v placebo

Outcome: 1 Participants with at least 50\% pain relief over 4 to 6 hours

\begin{tabular}{|c|c|c|c|c|c|c|}
\hline Study or subgroup & $\begin{array}{r}\text { Didofenac } 25 \mathrm{mg} \\
\mathrm{n} / \mathrm{N}\end{array}$ & $\begin{array}{r}\text { Placebo } \\
\mathrm{n} / \mathrm{N}\end{array}$ & \multicolumn{2}{|c|}{$\begin{array}{c}\text { Risk Ratio } \\
\text { M-H,Fixed,95\% C } \\
\end{array}$} & Weight & $\begin{array}{r}\text { Risk Ratio } \\
\text { M-H,Fixed,95\% Cl }\end{array}$ \\
\hline Hersh 2004 & $34 / 63$ & $11 / 68$ & & -- & $29.0 \%$ & $3.34[1.85,6.00]$ \\
\hline Kubitzek 2003 & $42 / 83$ & $7 / 84$ & & $\rightarrow$ & $19.0 \%$ & $6.07[2.90,12.73]$ \\
\hline Nelson 1994 & $23 / 50$ & 4/50 & & $\longrightarrow$ & $10.9 \%$ & $5.75[2.14,15.42]$ \\
\hline Olson 1997 & $32 / 52$ & $15 / 52$ & & - & $41.1 \%$ & $2.13[1.32,3.44]$ \\
\hline Total $(95 \% \mathrm{CI})$ & 248 & 254 & & - & $100.0 \%$ & $3.63[2.64,4.98]$ \\
\hline \multirow{4}{*}{\multicolumn{7}{|c|}{$\begin{array}{l}\text { Total events: I3I (Diclofenac } 25 \mathrm{mg}), 37 \text { (Placebo) } \\
\text { Heterogeneity: Chi }{ }^{2}=7.52, \text { df }=3(P=0.06) ; F^{2}=60 \% \\
\text { Test for overall effect: } Z=7.95 \text { ( }(P<0.0000 \mathrm{I}) \\
\text { Test for subgroup differences: Not applicable }\end{array}$}} \\
\hline & & & & & & \\
\hline & & & & & & \\
\hline & & & & & & \\
\hline \multicolumn{7}{|c|}{ 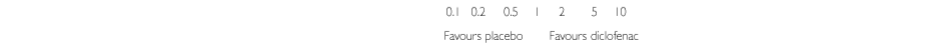 } \\
\hline
\end{tabular}

\section{Analysis 2.1. Comparison 2 Diclofenac $50 \mathrm{mg}$ v placebo, Outcome 1 Participants with at least $50 \%$ pain relief over 4 to 6 hours}

Review: Single dose oral diclofenac for acute postoperative pain in adults

Comparison: 2 Diclofenac $50 \mathrm{mg}$ v placebo

Outcome: 1 Participants with at least 50\% pain relief over 4 to 6 hours 


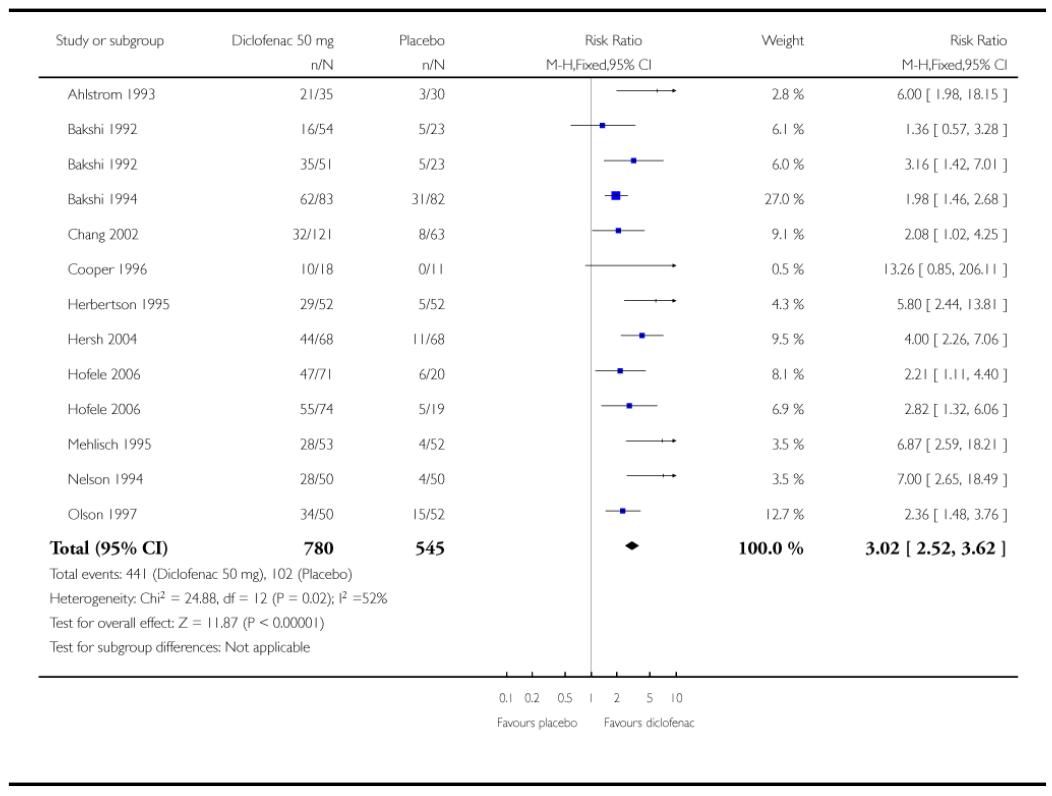

\section{Analysis 2.2. Comparison 2 Diclofenac $50 \mathrm{mg}$ v placebo, Outcome 2 Participants with at least $50 \%$ pain relief over 4 to 6 hours, dental or other surgery}

Review: Single dose oral diclofenac for acute postoperative pain in adults

Comparison: 2 Diclofenac $50 \mathrm{mg}$ v placebo

Outcome: 2 Participants with at least 50\% pain relief over 4 to 6 hours, dental or other surgery 


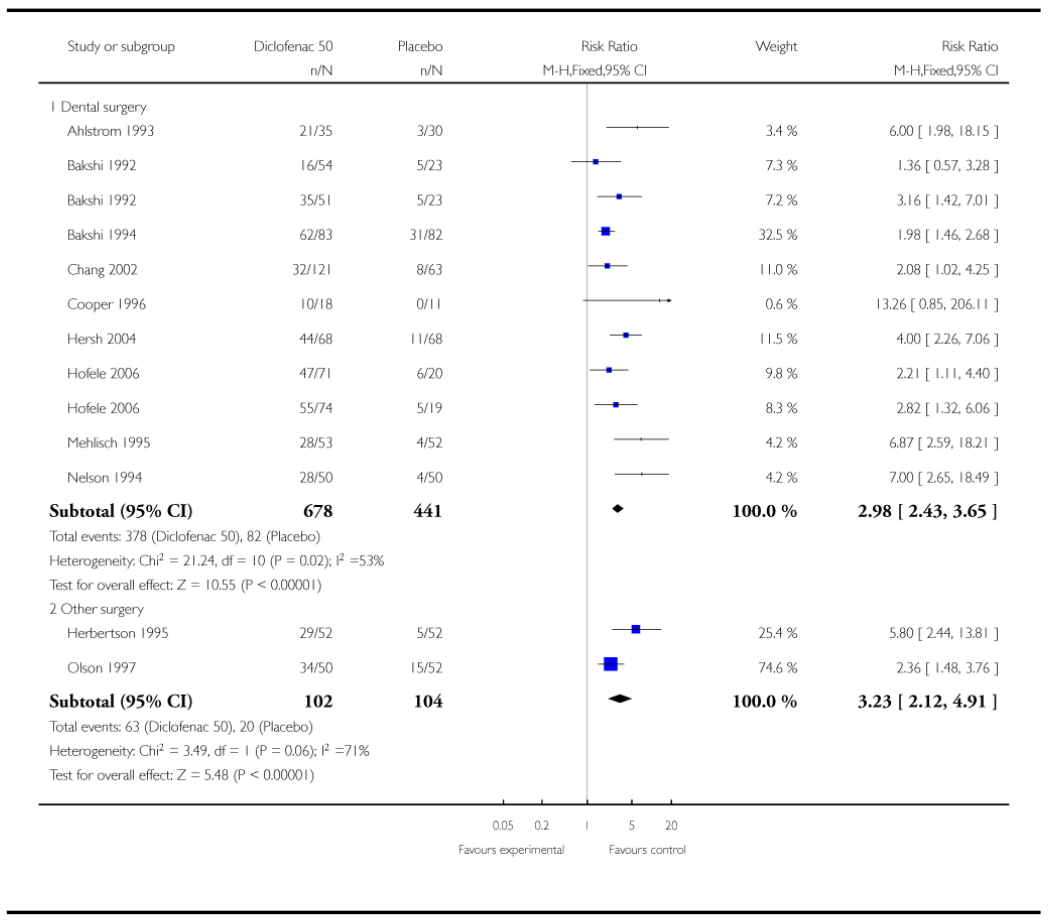

\section{Analysis 2.3. Comparison 2 Diclofenac $50 \mathrm{mg}$ v placebo, Outcome 3 Participants with at least $50 \%$ pain relief over 4 to 6 hours, $\mathrm{Na}$ or K salt}

Review: Single dose oral diclofenac for acute postoperative pain in adults Comparison: 2 Diclofenac $50 \mathrm{mg}$ v placebo

Outcome: 3 Participants with at least $50 \%$ pain relief over 4 to 6 hours, Na or K salt 


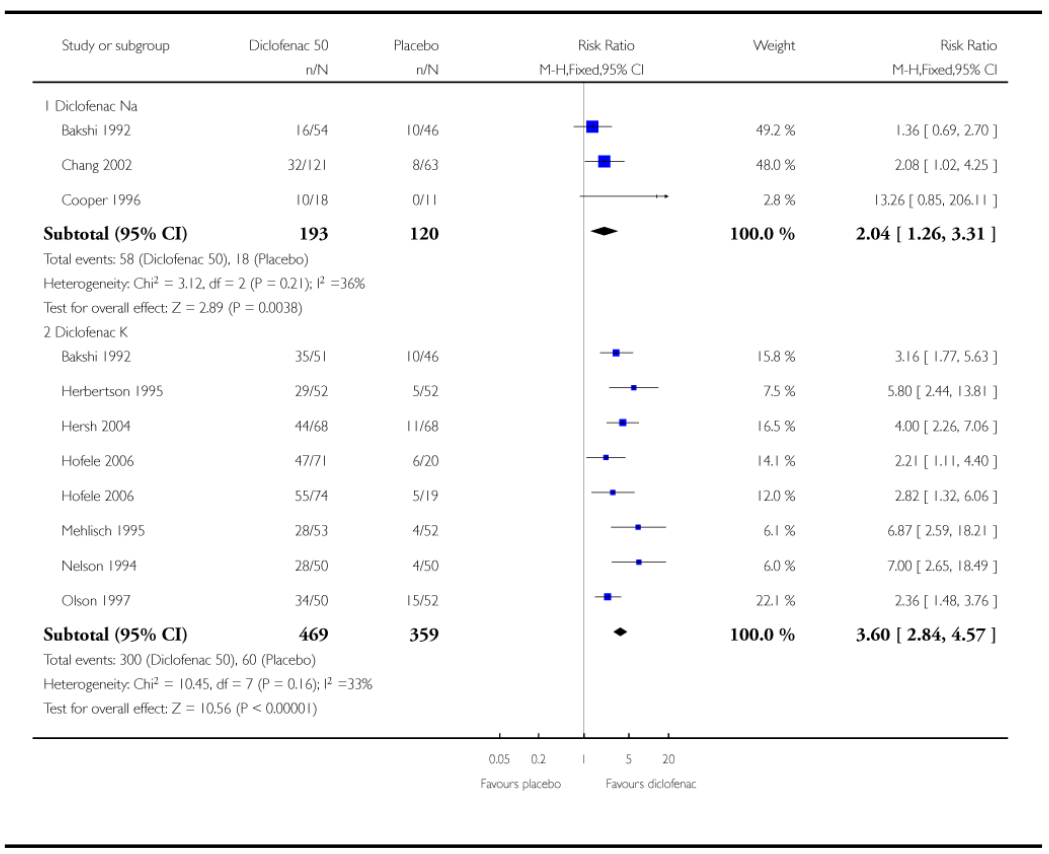

\section{Analysis 3.1. Comparison 3 Diclofenac $100 \mathrm{mg}$ v placebo, Outcome 1 Participants with at least $50 \%$ pain relief over 4 to 6 hours}

Review: Single dose oral diclofenac for acute postoperative pain in adults

Comparison: 3 Diclofenac $100 \mathrm{mg}$ v placebo

Outcome: 1 Participants with at least $50 \%$ pain relief over 4 to 6 hours

\begin{tabular}{|c|c|c|c|c|c|c|}
\hline Study or subgroup & $\begin{array}{r}\text { Diclofenac } 100 \mathrm{mg} \\
\mathrm{n} / \mathrm{N}\end{array}$ & $\begin{array}{r}\text { Placebo } \\
n / N\end{array}$ & \multicolumn{2}{|c|}{$\begin{array}{c}\text { Risk Ratio } \\
\text { M-H.Fixed,95\% Cl }\end{array}$} & Weight & $\begin{array}{r}\text { Risk Ratio } \\
\text { M-H,Fixed,95\% C }\end{array}$ \\
\hline Desjardins 2004 & 13/85 & 4/82 & & $\longrightarrow$ & $9.2 \%$ & $3.14[1.07,9.22]$ \\
\hline Herbertson 1995 & $29 / 52$ & $5 / 52$ & & $\rightarrow-$ & $11.3 \%$ & $5.80[2.44,13.81]$ \\
\hline Hersh 2004 & 52166 & $11 / 68$ & & - & $24.4 \%$ & $4.87[2.80,8.49]$ \\
\hline Mehlisch 1995 & $35 / 52$ & 4/52 & & $\longrightarrow$ & $9.0 \%$ & $8.75[3.35,22.86]$ \\
\hline Nelson 1994 & $35 / 50$ & $4 / 50$ & & $\longrightarrow$ & $9.0 \%$ & $8.75[3.36,22.79]$ \\
\hline Olson 1997 & $37 / 51$ & $15 / 52$ & & 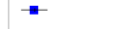 & $33.5 \%$ & $2.52[1.59,3.98]$ \\
\hline Zuniga 2004 & $12 / 31$ & $0 / 8$ & & $\longrightarrow$ & $1.8 \%$ & $7.03[0.46,107.62]$ \\
\hline Zuniga 2004 & 1729 & $0 / 7$ & & $\longrightarrow$ & $1.8 \%$ & $9.33[0.63,138.99]$ \\
\hline Total $(95 \%$ CI $)$ & 416 & 371 & & - & $100.0 \%$ & $4.84[3.63,6.47]$ \\
\hline \multirow{4}{*}{\multicolumn{7}{|c|}{$\begin{array}{l}\text { Total events: } 230 \text { (Diclofenac 100mg). } 43 \text { (Placebo) } \\
\text { Heterogeneity. Chi }=11.84 \text {, df }=7(P=0.11) ; 1^{2}=41 \% \\
\text { Test for overall effect: } Z=10.70(P<0.00001) \\
\text { Test for subgroup differences: Not applicable }\end{array}$}} \\
\hline & & & & & & \\
\hline & & & & & & \\
\hline & & & & & & \\
\hline & & & $0.05 \quad 0.2$ & $5 \quad 20$ & & \\
\hline & & & Favours placebo & Favours dicibofenac & & \\
\hline
\end{tabular}




\section{Analysis 3.2. Comparison 3 Diclofenac $100 \mathrm{mg}$ v placebo, Outcome 2 Participants with at least $50 \%$ pain relief over 4 to 6 hours, dental or other surgery}

Review: Single dose oral diclofenac for acute postoperative pain in adults

Comparison: 3 Diclofenac $100 \mathrm{mg}$ v placebo

Outcome: 2 Participants with at least $50 \%$ pain relief over 4 to 6 hours, dental or other surgery

\begin{tabular}{|c|c|c|c|c|c|c|}
\hline Study or subgroup & $\begin{array}{r}\text { Diclofenac } 100 \\
\mathrm{n} / \mathrm{N}\end{array}$ & $\begin{array}{r}\text { Placebo } \\
n / N\end{array}$ & \multicolumn{2}{|c|}{$\begin{array}{c}\text { Risk Ratio } \\
\text { M-H.Fixed,95\% CI }\end{array}$} & Weight & $\begin{array}{r}\text { Risk Ratio } \\
\text { M-H,Fixed,95\% C }\end{array}$ \\
\hline \multicolumn{7}{|l|}{ I Dental surgery } \\
\hline Hersh 2004 & $52 / 66$ & 11/68 & & $=$ & $24.4 \%$ & $4.87[2.80,8.49]$ \\
\hline Mehlisch 1995 & $35 / 52$ & 4/52 & & $\cdots$ & $9.0 \%$ & $8.75[3.35,22.86]$ \\
\hline Nelson 1994 & $35 / 50$ & $4 / 50$ & & $\longrightarrow$ & $9.0 \%$ & $8.75[3.36,22.79]$ \\
\hline Zuniga 2004 & $16 / 29$ & $0 / 8$ & & $\longrightarrow$ & $1.7 \%$ & $9.90[0.66,149.25]$ \\
\hline Zuniga 2004 & $13 / 3 \mid$ & or & & $\longrightarrow$ & $1.8 \%$ & $6.75[0.45,101.88]$ \\
\hline Subtotal $(95 \% \mathrm{CI})$ & 228 & 185 & & - & $46.0 \%$ & $6.65[4.34,10.21]$ \\
\hline \multicolumn{7}{|c|}{ Total events: 151 (Didofenac 100), 19 (Placebo) } \\
\hline \multicolumn{7}{|c|}{ Heterogeneity. $C h i^{2}=1.92, d f=4(P=0.75) ; 1^{2}=0.0 \%$} \\
\hline \multicolumn{7}{|c|}{ Test for overall effect: $Z=8.67(P<0.00001)$} \\
\hline \multicolumn{7}{|l|}{2 Other surgery } \\
\hline Desjardins 2004 & 13/85 & 4/82 & & $\cdot$ & $9.2 \%$ & $3.14[1.07,9.22]$ \\
\hline Herbertson 1995 & $29 / 52$ & $5 / 52$ & & $\cdots$ & $11.3 \%$ & $5.80[2.44,13.81]$ \\
\hline Olson 1997 & $37 / 51$ & 15/52 & & - & $33.5 \%$ & $2.52[1.59,3.98]$ \\
\hline Subtotal $(95 \% \mathrm{CI})$ & 188 & 186 & & - & $54.0 \%$ & $3.31[2.24,4.88]$ \\
\hline \multicolumn{7}{|c|}{ Total events: 79 (Diclofenac 100), 24 (Placebo) } \\
\hline \multicolumn{7}{|c|}{ Heterogeneity: $\mathrm{Ch}^{2}=2.99, \mathrm{df}=2(\mathrm{P}=0.22) ; \mathrm{I}^{2}=33 \%$} \\
\hline \multicolumn{7}{|c|}{ Test for overall effect: $Z=6.02(P<0.00001)$} \\
\hline Total $(95 \% \mathrm{CI})$ & 416 & 371 & & - & $100.0 \%$ & $4.85[3.63,6.47]$ \\
\hline \multicolumn{7}{|c|}{ Total events: 230 (Diclofenac 100), 43 (Placebo) } \\
\hline \multicolumn{7}{|c|}{ Heterogeneity: $C h^{2}=11.88, d f=7(P=0.10) ; 1^{2}=41 \%$} \\
\hline \multicolumn{7}{|c|}{ Test for overall effect $Z=10.71(P<0.00001)$} \\
\hline \multicolumn{7}{|c|}{ Test for subgroup differences: $C h i^{2}=5.61$, df $=1(P=0.02), l^{2}=82 \%$} \\
\hline & & & $0.05 \quad 0.2$ & $5 \quad 20$ & & \\
\hline
\end{tabular}

\section{Analysis 3.3. Comparison 3 Diclofenac $100 \mathrm{mg}$ v placebo, Outcome 3 Participants with at least $50 \%$ pain relief over 4 to 6 hours, Na or K salt}

Review: Single dose oral diclofenac for acute postoperative pain in adults

Comparison: 3 Diclofenac $100 \mathrm{mg}$ v placebo

Outcome: 3 Participants with at least $50 \%$ pain relief over 4 to 6 hours, Na or K salt 


\begin{tabular}{|c|c|c|c|c|c|c|}
\hline Study or subgroup & $\begin{array}{r}\text { Diclofenac } 100 \\
\mathrm{n} / \mathrm{N}\end{array}$ & $\begin{array}{r}\text { Placebo } \\
n / N\end{array}$ & \multicolumn{2}{|c|}{$\begin{array}{c}\text { Risk Ratio } \\
\text { M-H,Fixed,95\% CII }\end{array}$} & Weight & $\begin{array}{r}\text { Risk Ratio } \\
\text { M-H,Fixed,95\% CI }\end{array}$ \\
\hline $\begin{array}{l}\text { I Diclofenac Na } \\
\text { Desjardins } 2004\end{array}$ & 13/85 & 4/82 & & $=-$ & $86.2 \%$ & $3.14[1.07,9.22]$ \\
\hline Zuniga 2004 & 1729 & 0/15 & & $\longrightarrow$ & $13.8 \%$ & $18.67[1.20,290.50]$ \\
\hline \multicolumn{7}{|c|}{$\begin{array}{l}\text { Total events: } 30 \text { (Didofénac 100), } 4 \text { (Placebo) } \\
\text { Heterogeneity: Chi' }=1.71, \text { dif }=1(P=0.19) ; 1^{2}=42 \% \\
\text { Test for overal effect: } Z=3.23(P=0.0013)\end{array}$} \\
\hline $\begin{array}{l}2 \text { Diclofenac K } \\
\text { Herbertson } 1995\end{array}$ & 29152 & $5 / 52$ & & $\rightarrow$ & $127 \%$ & $5.80[2.44,13.81]$ \\
\hline Hersh 2004 & $52 / 66$ & 11168 & & - & $27.5 \%$ & $4.87[2.80,8.49]$ \\
\hline Mehisch 1995 & $35 / 52$ & 4/52 & & $\cdots$ & $10.2 \%$ & $8.75[3.35,22.86]$ \\
\hline Neson 1994 & 35150 & $4 / 50$ & & $\cdots$ & $10.2 \%$ & $8.75[3.36,2279]$ \\
\hline Olson 1997 & $37 / 51$ & |5/52 & & $=$ & $37.7 \%$ & $2.52[1.59,3.98]$ \\
\hline Zuniga 2004 & |2/31 & 0/15 & & ․ & $1.7 \%$ & $12.50[0.79,197.95]$ \\
\hline \multicolumn{7}{|c|}{$\begin{array}{l}\text { Total events: } 200 \text { (Didofenac 100), } 39 \text { (Placebo) } \\
\text { Heterogeneity: Chi }{ }^{2}=11.82 \text { df }=5(P=0.04) ; I^{2}=58 \% \\
\text { Test for overall effect: } Z=10.52(P<0.00001)\end{array}$} \\
\hline & & & & $\begin{array}{cc}5 & 20 \\
\text { Faxpurs control }\end{array}$ & & \\
\hline
\end{tabular}

\section{Analysis 4.1. Comparison 4 Diclofenac versus placebo, Outcome 1 Participants with at least one adverse event}

Review: Single dose oral diclofenac for acute postoperative pain in adults

Comparison: 4 Diclofenac versus placebo

Outcome: 1 Participants with at least one adverse event 


\begin{tabular}{|c|c|c|c|c|c|}
\hline Study or subgroup & $\begin{array}{r}\text { Diclofenac } \\
n / N\end{array}$ & $\begin{array}{r}\text { Placebo } \\
\mathrm{n} / \mathrm{N}\end{array}$ & $\begin{array}{c}\text { Risk Ratio } \\
\text { M-H,Fixed,95\% Cl }\end{array}$ & Weight & $\begin{array}{r}\text { Risk Ratio } \\
\text { M-H,Fixed,95\% CI }\end{array}$ \\
\hline \multicolumn{6}{|l|}{ I Diclofenac $25 \mathrm{mg}$} \\
\hline Hersh 2004 & $8 / 63$ & 9/68 & -- & $49.1 \%$ & $0.96[0.39,2.33]$ \\
\hline Kubitzek 2003 & 6/83 & 2/84 & $\longrightarrow$ & $11.3 \%$ & $3.04[0.63,14.61]$ \\
\hline Nelson 1994 & $5 / 50$ & $6 / 50$ & -- & $34.0 \%$ & $0.83[0.27,2.55]$ \\
\hline Olson 1997 & 1/52 & 1/52 & 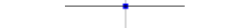 & $5.7 \%$ & $1.00[0.06,15.57]$ \\
\hline Subtotal $(95 \% \mathrm{CI})$ & 248 & 254 & - & $100.0 \%$ & $1.15[0.63,2.11]$ \\
\hline \multicolumn{6}{|c|}{ Total events: 20 (Diclofenac), 18 (Placebo) } \\
\hline \multicolumn{6}{|c|}{ Heterogeneity. $C h i^{2}=1.96, d f=3(P=0.58) ; R^{2}=0.0 \%$} \\
\hline \multicolumn{6}{|c|}{ Test for overall effect: $Z=0.46(P=0.65)$} \\
\hline \multicolumn{6}{|c|}{2 Diclofenac $50 \mathrm{mg}$} \\
\hline Ahistrom 1993 & 6/35 & 2/30 & $\cdot$ & $5.8 \%$ & $2.57[0.56,11.81]$ \\
\hline Bakshi 1992 & 3/51 & 1/23 & & $3.7 \%$ & $1.35[0.15,12.32]$ \\
\hline Bakshi 1992 & 1/54 & 2/23 & $\cdot$ & $7.6 \%$ & $0.21[0.02,2.23]$ \\
\hline Bakshi 1994 & 4/83 & 5/82 & & $13.6 \%$ & $0.79[0.22 .2 .84]$ \\
\hline Herbertson 1995 & 6/54 & $2 / 54$ & $=$ & $5.4 \%$ & $3.00[0.63,14.21]$ \\
\hline Hersh 2004 & $8 / 68$ & 9/68 & $\rightarrow$ & $24.3 \%$ & $0.89[0.36,2.17]$ \\
\hline Hofele 2006 & 277 & 1/20 & & $4.2 \%$ & $0.56[0.05,5.90]$ \\
\hline Hofele 2006 & 2774 & 1/19 & 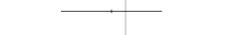 & $4.3 \%$ & $0.51[0.05,5.37]$ \\
\hline Mehlisch 1995 & $5 / 53$ & 4/52 & - & $10.9 \%$ & $1.23[0.35,4.31]$ \\
\hline Nelson 1994 & 4/50 & 6/50 & $\longrightarrow$ & $16.2 \%$ & $0.67[0.20,2.22]$ \\
\hline Olson 1997 & 0/50 & 1/52 & . & $4.0 \%$ & $0.35[0.01,8.31]$ \\
\hline Subtotal $(95 \% \mathrm{CI})$ & 643 & 473 & 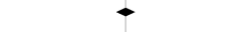 & $100.0 \%$ & $1.00[0.65,1.55]$ \\
\hline \multicolumn{6}{|c|}{ Total events: 41 (Diclofenac), 34 (Placebo) } \\
\hline \multicolumn{6}{|c|}{ Heterogeneity: $C \mathrm{Ch}^{2}=6.83, \mathrm{df}=10(\mathrm{P}=0.74) ; 1^{2}=0.0 \%$} \\
\hline \multicolumn{6}{|c|}{ Test for overall effect: $Z=0.01(P=0.99)$} \\
\hline \multicolumn{6}{|l|}{3 Diclofenac $100 \mathrm{mg}$} \\
\hline Desjardins 2004 & $38 / 85$ & $41 / 82$ & - & $64.0 \%$ & $0.89[0.65,1.23]$ \\
\hline \multirow[t]{2}{*}{ Herbertson 1995} & $6 / 55$ & $2 / 54$ & - & $3.1 \%$ & $2.95[0.62,13.96]$ \\
\hline & & & 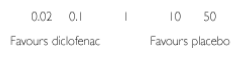 & & \\
\hline Study or subgroup & Diclofenac & Placebo & Risk Ratio & Weight & Risk Ratio \\
\hline & $\mathrm{n} / \mathrm{N}$ & $n / N$ & M-H,Fixed,95\% Cl & & M-H,Fixed,95\% Cl \\
\hline Hersh 2004 & $7 / 66$ & 9/68 & - & $13.6 \%$ & $0.80[0.32,203]$ \\
\hline Mehlisch 1995 & $8 / 52$ & $4 / 52$ & $=$ & $6.1 \%$ & $2.00[0.64,6.23]$ \\
\hline Nelson 1994 & $4 / 50$ & $6 / 50$ & 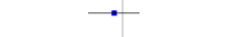 & $9.2 \%$ & $0.67[0.20,2.22]$ \\
\hline Oson 1997 & 1/51 & 1/52 & - & $1.5 \%$ & $1.02[0.07,15.87]$ \\
\hline Zuniga 2004 & $5 / 31$ & $0 / 8$ & - & $1.2 \%$ & $3.09[0.19,50.83]$ \\
\hline Zuniga 2004 & $5 / 29$ & $0 / 7$ & & $1.2 \%$ & $2.93[0.18,47.66]$ \\
\hline Subtotal $(95 \% \mathrm{CI})$ & 419 & 373 & - & $100.0 \%$ & $1.04[0.79,1.39]$ \\
\hline \multicolumn{6}{|c|}{ Total events: 74 (Diclofenac), 63 (Placebo) } \\
\hline \multirow{2}{*}{\multicolumn{6}{|c|}{$\begin{array}{l}\text { Heterogeneity: } \mathrm{Ch}^{2}=5.82, \mathrm{df}=7(P=0.56) ; \mathrm{R}^{2}=0.0 \% \\
\text { Test for overall effect: } Z=0.30(P=0.76)\end{array}$}} \\
\hline & & & & & \\
\hline & & & 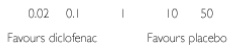 & & \\
\hline
\end{tabular}

\section{Analysis 4.2. Comparison 4 Diclofenac versus placebo, Outcome 2 Participants using rescue medication at 6 hours}

Review: Single dose oral diclofenac for acute postoperative pain in adults

Comparison: 4 Diclofenac versus placebo

Outcome: 2 Participants using rescue medication at 6 hours 


\begin{tabular}{|c|c|c|c|c|c|c|}
\hline Study or subgroup & $\begin{array}{r}\text { Diclofenac } \\
\mathrm{n} / \mathrm{N}\end{array}$ & $\begin{array}{l}\text { Placebo } \\
\mathrm{n} / \mathrm{N}\end{array}$ & $\begin{array}{r}R \\
M-H, F i x\end{array}$ & $\begin{array}{l}\text { Ratio } \\
.95 \% \mathrm{Cl}\end{array}$ & Weight & $\begin{array}{r}\text { Risk Ratio } \\
\text { M-H,Fixed, } 95 \% \mathrm{CI}\end{array}$ \\
\hline \multicolumn{7}{|l|}{ I Diclofenac $25 \mathrm{mg}$} \\
\hline Hersh 2004 & $32 / 63$ & $54 / 68$ & \# & & $29.1 \%$ & $0.64[0.49,0.84]$ \\
\hline Kubitzek 2003 & $64 / 83$ & $75 / 84$ & - & & $41.8 \%$ & $0.86[0.75,0.99]$ \\
\hline Nelson 1994 & $29 / 51$ & $33 / 51$ & * & & $18.5 \%$ & $0.88[0.64,1.20]$ \\
\hline Olson 1997 & 2/52 & $19 / 52$ & $\hookleftarrow$ & & $10.6 \%$ & $0.11[0.03,0.43]$ \\
\hline Subtotal $(95 \% \mathrm{CI})$ & 249 & 255 & - & & $100.0 \%$ & $0.72[0.63,0.82]$ \\
\hline \multicolumn{7}{|c|}{ Total events: 127 (Diclofenac), 181 (Placebo) } \\
\hline \multicolumn{7}{|c|}{ Heterogeneity: $C \mathrm{Ch}^{2}=16.03, \mathrm{df}=3(P=0.001): 1^{2}=81 \%$} \\
\hline \multicolumn{7}{|c|}{ Test for overall effect: $Z=4.94(P<0.00001)$} \\
\hline \multicolumn{7}{|l|}{2 Diclofenac $50 \mathrm{mg}$} \\
\hline Ahlstrom 1993 & $14 / 35$ & $23 / 30$ & - & & $8.0 \%$ & $0.52[0.33,0.82]$ \\
\hline Bakshi 1992 & $22 / 54$ & $14 / 23$ & $\rightarrow$ & & $6.4 \%$ & $0.67[0.42,1.06]$ \\
\hline Bakshi 1992 & $17 / 51$ & 13/23 & $\rightarrow$ & & $5.8 \%$ & $0.59[0.35,1.00]$ \\
\hline Bakshi 1994 & $20 / 83$ & $53 / 82$ & 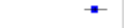 & & $17.3 \%$ & $0.37[0.25,0.56]$ \\
\hline Herbertson 1995 & $26 / 52$ & $43 / 52$ & - & & $13.9 \%$ & $0.60[0.45,0.82]$ \\
\hline Hersh 2004 & $25 / 68$ & $54 / 68$ & 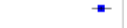 & & $17.5 \%$ & $0.46[0.33,0.65]$ \\
\hline Mehlisch 1995 & $26 / 53$ & 44/52 & - & & $14.4 \%$ & $0.58[0.43,0.78]$ \\
\hline Nelson 1994 & $20 / 51$ & $33 / 51$ & $\Rightarrow$ & & $10.7 \%$ & $0.61[0.41,0.90]$ \\
\hline Olson 1997 & $2 / 50$ & 19/52 & $\bullet$ & & $6.0 \%$ & $0.11[0.03,0.45]$ \\
\hline Subtotal $(95 \% \mathrm{CI})$ & 497 & 433 & - & & $100.0 \%$ & $0.50[0.44,0.58]$ \\
\hline \multicolumn{7}{|c|}{ Total events: 172 (Diclofenac), 296 (Placebo) } \\
\hline \multicolumn{7}{|c|}{ Heterogeneity: $C \mathrm{Ch}^{2}=11.81, \mathrm{df}=8(\mathrm{P}=0.16) ; 1^{2}=32 \%$} \\
\hline \multicolumn{7}{|c|}{ Test for overall effect: $Z=9.91(P<0.00001)$} \\
\hline \multicolumn{7}{|l|}{3 Diclofenac $100 \mathrm{mg}$} \\
\hline Herbertson 1995 & $28 / 52$ & $43 / 52$ & $*$ & & $18.4 \%$ & $0.65[0.49,0.86]$ \\
\hline Hersh 2004 & $21 / 66$ & $54 / 68$ & 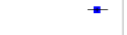 & & $227 \%$ & $0.40[0.28,0.58]$ \\
\hline Mehlisch 1995 & $16 / 52$ & 44/52 & 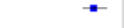 & & $18.8 \%$ & $0.36[0.24,0.56]$ \\
\hline \multirow[t]{2}{*}{ Nelson 1994} & $16 / 51$ & $33 / 51$ & $\rightarrow$ & & $14.1 \%$ & $0.48[0.31,0.76]$ \\
\hline & & & $\begin{array}{cc}0.05 \quad 0.2 \\
\text { Favours diclofenac }\end{array}$ & $\begin{array}{c}5 \quad 20 \\
\text { Favours placebo }\end{array}$ & & \\
\hline \multirow[t]{2}{*}{ Study or subgroup } & Diclofenac & Placebo & \multirow{2}{*}{\multicolumn{2}{|c|}{$\begin{array}{c}\text { Risk Ratio } \\
\text { M-H,Fixed,95\% CI }\end{array}$}} & Weight & Risk Ratic \\
\hline & $\mathrm{n} / \mathrm{N}$ & $\mathrm{n} / \mathrm{N}$ & & & & M-H,Fixed,95\% C \\
\hline Olson 1997 & $1 / 51$ & 20152 & • & & $8.5 \%$ & $0.05[0.01,0.37]$ \\
\hline Zuniga 2004 & $22 / 31$ & $15 / 15$ & * & & $8.8 \%$ & $0.73[0.57,0.92]$ \\
\hline Zuniga 2004 & $20 / 29$ & $15 / 15$ & * & & $8.6 \%$ & $0.71[0.54,0.91]$ \\
\hline Subtotal $(95 \% \mathrm{CI})$ & 332 & 305 & - & & $100.0 \%$ & $0.48[0.41,0.56]$ \\
\hline \multirow{3}{*}{\multicolumn{7}{|c|}{$\begin{array}{l}\text { Total events: } 124 \text { (Diclofenac), } 224 \text { (Placebo) } \\
\text { Heterogeneity. Chi' }{ }^{2}=32.41, \text { df }=6(P=0.00001): 1^{2}=81 \% \\
\text { Test for overall effect: } Z=9.54(P<0.00001)\end{array}$}} \\
\hline & & & & & & \\
\hline & & & & & & \\
\hline & & & $0.05 \quad 0.2$ & $5 \quad 20$ & & \\
\hline & & & Favours diclofenac & Favours placebo & & \\
\hline
\end{tabular}

\section{Appendix 1. Search strategy for MEDLINE via Ovid}

1. Diclofenac.sh

2. diclofenac.ti,ab,kw.

3. $\mathrm{OR} / 1-2$

4. Pain, postoperative.sh

5. ((postoperative adj4 pain\$) or (post-operative adj4 pain\$) or post-operative-pain\$ or (post\$ NEAR pain\$) or (postoperative adj4 analgesi\$) or (post-operative adj4 analgesi\$) or (“post-operative analgesi\$”)).ti,ab,kw. 
6. ((post-surgical adj4 pain\$) or ("post surgical" adj4 pain\$) or (post-surgery adj4 pain\$)).ti,ab,kw.

7. ((“pain-relief after surg\$”) or ("pain following surg\$”) or ("pain control after")).ti,ab,kw.

8. ((“post surg\$” or post-surg\$) AND (pain\$ or discomfort)).ti,ab,kw.

9. ((pain\$ adj4 “after surg\$”) or (pain\$ adj4 "after operat\$”) or (pain\$ adj4 “follow\$ operat\$”) or (pain\$ adj4 “follow\$ surg\$”)).ti,ab,kw.

10. ((analgesi\$ adj4 “after surg\$”) or (analgesi\$ adj4 “after operat\$”) or (analgesi\$ adj4 “follow\$ operat\$”) or (analgesi\$ adj4 “follow\$ surg\$”)).ti,ab,kw.

11. $\mathrm{OR} / 4-10$

12. randomized controlled trial.pt.

13. controlled clinical trial.pt.

14. randomized.ab.

15. placebo.ab.

16. drug therapy.fs.

17. randomly.ab.

18. trial.ab.

19. groups.ab.

20. OR/12-19

21. humans.sh.

22. 20 AND 21

23. 3 AND 11 AND 22

For the earlier review the following brand names were also searched:

allvoran; dolotren; nu-diclo; anfenax; ecofenac; olfen; apo-diclo; effekton; panamor; arcanafenac; fenac; pharmaflam; arthrotec; fenaren; polyflam; benfofen; flamrase; primofenac; brovaflamp; flector; rewodina; cataflam; flexagen; rheufenac; clinifam; flogofenac; rheumasan; dedolor; forgenac; rhumalgan; deflamat; fortfen; ribex; delphimix; grofenac; sigafenac; delphinac; inflamac; silino; diclac; isclofen; sodiclo; diclo; jenafenac; toryxil; diclobene; lexobene; tratul; dicloberl; liberalgium; valenac; diclofex; luase; veltex; diclomax; magluphen; voldal; diclomelan; monoflam; vologen; dicloreum; motifene; volraman; diclosyl; myogit; voltaren; diclozip; naclof; voltarene; dignofenac; novapirina; voltarol; dolobasan; novo-difenac; xenid.

\section{Appendix 2. Search strategy for EMBASE via Ovid}

1. Diclofenac.sh 
2. diclofenac.ti,ab,kw.

3. $\mathrm{OR} / 1-2$

4. Postoperative pain.sh

5. ((postoperative adj4 pain\$) or (post-operative adj4 pain\$) or post-operative-pain\$ or (post\$ NEAR pain\$) or (postoperative adj4 analgesi\$) or (post-operative adj4 analgesi\$) or (“post-operative analgesi\$”)).ti,ab,kw.

6. ((post-surgical adj4 pain\$) or ("post surgical” adj4 pain\$) or (post-surgery adj4 pain\$)).ti,ab,kw.

7. ((“pain-relief after surg\$”) or ("pain following surg\$”) or ("pain control after")).ti,ab,kw.

8. ((“post surg\$” or post-surg\$) AND (pain\$ or discomfort)).ti,ab,kw.

9. ((pain\$ adj4 “after surg\$”) or (pain\$ adj4 "after operat\$”) or (pain\$ adj4 “follow\$ operat\$”) or (pain\$ adj4 “follow\$ surg\$”)).ti,ab,kw.

10. ((analgesi\$ adj4 “after surg\$”) or (analgesi\$ adj4 “after operat\$”) or (analgesi\$ adj4 "follow\$ operat\$”) or (analgesi\$ adj4 “follow\$ surg\$”)).ti,ab,kw.

11. $\mathrm{OR} / 4-10$

12. clinical trials.sh

13. controlled clinical trials.sh

14. randomized controlled trial.sh

15. double-blind procedure.sh

16. (clin\$ adj25 trial\$).ab

17. ((doubl\$ or trebl\$ or tripl\$) adj25 (blind\$ or mask\$)).ab

18. placebo\$.ab

19. random $\$ . a b$

20. $\mathrm{OR} / 12-19$

\section{3 AND 11 AND 20}

For the earlier review the following brand names were also searched:

allvoran; dolotren; nu-diclo; anfenax; ecofenac; olfen; apo-diclo; effekton; panamor; arcanafenac; fenac; pharmaflam; arthrotec; fenaren; polyflam; benfofen; flamrase; primofenac; brovaflamp; flector; rewodina; cataflam; flexagen; rheufenac; clinifam; flogofenac; rheumasan; dedolor; forgenac; rhumalgan; deflamat; fortfen; ribex; delphimix; grofenac; sigafenac; delphinac; inflamac; silino; diclac; isclofen; sodiclo; diclo; jenafenac; toryxil; diclobene; lexobene; tratul; dicloberl; liberalgium; valenac; diclofex; luase; veltex; diclomax; magluphen; voldal; diclomelan; monoflam; vologen; dicloreum; motifene; volraman; diclosyl; myogit; voltaren; diclozip; naclof; voltarene; dignofenac; novapirina; voltarol; dolobasan; novo-difenac; xenid. 


\section{Appendix 3. Search strategy for Cochrane CENTRAL}

1. MESH descriptor Diclofenac

2. diclofenac:ti,ab,kw.

3. $\mathrm{OR} / 1-2$

4. MESH descriptor Pain, Postoperative

5. ((postoperative adj4 pain\$) or (post-operative adj4 pain\$) or post-operative-pain\$ or (post\$ NEAR pain\$) or (postoperative adj4 analgesi\$) or (post-operative adj4 analgesi\$) or (“post-operative analgesi\$”)):ti,ab,kw.

6. ((post-surgical adj4 pain\$) or ("post surgical” adj4 pain\$) or (post-surgery adj4 pain\$)):ti,ab,kw.

7. ((“pain-relief after surg\$”) or ("pain following surg\$”) or ("pain control after")):ti,ab,kw.

8. ((“post surg\$” or post-surg\$) AND (pain\$ or discomfort)):ti,ab,kw.

9. ((pain\$ adj4 “after surg\$”) or (pain\$ adj4 “after operat\$”) or (pain\$ adj4 “follow\$ operat\$”) or (pain\$ adj4 “follow\$ surg\$”)): ti,ab,kw.

10. ((analgesi\$ adj4 “after surg\$”) or (analgesi\$ adj4 “after operat\$”) or (analgesi $\$$ adj4 "follow\$ operat\$”) or (analgesi\$ adj4 “follow\$ surg\$”)):ti,ab,kw.

11. $\mathrm{OR} / 4-10$

12. Clinical trials:pt.

13. Controlled Clinical Trial:pt.

14. Randomized Controlled Trial.pt.

15. MESH descriptor Double-Blind Method

16. (clin\$ adj25 trial\$):ti,ab,kw.

17. ((doubl\$ or trebl\$ or tripl\$) adj25 (blind\$ or mask\$)):ti,ab,kw.

18. placebo\$:ti,ab,kw.

19. random $\$: \mathrm{ti}, \mathrm{ab}, \mathrm{kw}$.

20. $\mathrm{OR} / 12-19$

21. 3 AND 11 AND 20

\section{Appendix 4. Glossary}

Categorical rating scale

The commonest is the five category scale (none, slight, moderate, good or lots, and complete). For analysis numbers are given to the verbal categories (for pain intensity, none $=0$, mild $=1$, moderate $=2$ and severe $=3$, and for relief none $=0$, slight $=1$, moderate $=2$, 
good or lots $=3$ and complete $=4$ ). Data from different subjects is then combined to produce means (rarely medians) and measures of dispersion (usually standard errors of means). The validity of converting categories into numerical scores was checked by comparison with concurrent visual analogue scale measurements. Good correlation was found, especially between pain relief scales using cross-modality matching techniques. Results are usually reported as continuous data, mean or median pain relief or intensity. Few studies present results as discrete data, giving the number of participants who report a certain level of pain intensity or relief at any given assessment point. The main advantages of the categorical scales are that they are quick and simple. The small number of descriptors may force the scorer to choose a particular category when none describes the pain satisfactorily.

\section{VAS}

Visual analogue scale: lines with left end labelled "no relief of pain" and right end labelled "complete relief of pain", seem to overcome this limitation. Patients mark the line at the point which corresponds to their pain. The scores are obtained by measuring the distance between the no relief end and the patient's mark, usually in millimetres. The main advantages of VAS are that they are simple and quick to score, avoid imprecise descriptive terms and provide many points from which to choose. More concentration and coordination are needed, which can be difficult post-operatively or with neurological disorders.

\section{TOTPAR}

Total pain relief (TOTPAR) is calculated as the sum of pain relief scores over a period of time. If a patient had complete pain relief immediately after taking an analgesic, and maintained that level of pain relief for 6 hours, they would have a 6-hour TOTPAR of the maximum of 24. Differences between pain relief values at the start and end of a measurement period are dealt with by the composite trapezoidal rule. This is a simple method that approximately calculates the definite integral of the area under the pain relief curve by calculating the sum of the areas of several trapezoids that together closely approximate to the area under the curve.

\section{SPID}

Summed pain intensity difference (SPID) is calculated as the sum of the differences between the pain scores over a period of time. Differences between pain intensity values at the start and end of a measurement period are dealt with by the trapezoidal rule.

VAS TOTPAR and VAS SPID are visual analogue versions of TOTPAR and SPID.

See "Measuring pain" in Bandolier's Little Book of Pain, Oxford University Press, Oxford. 2003; pp 7-13 (Moore 2003).

\section{HISTORY}

Protocol first published: Issue 2, 2004 
Review first published: Issue 2, 2004

\begin{tabular}{lll}
\hline Date & Event & Description \\
\hline 8 February 2011 & Amended & Contact details updated. \\
\hline 24 September 2010 & Amended & Contact details updated. \\
\hline 23 December 2008 & $\begin{array}{l}\text { New citation } \\
\text { required and } \\
\text { conclusions have } \\
\text { changed }\end{array}$ & $\begin{array}{l}\text { Eight new studies (1206 participants in comparisons of diclofenac and } \\
\text { placebo) were added in December 2008 (Chang 2002; Cooper 1996; } \\
\text { Desjardins 2004; Hersh 2004; Hofele 2006; Kubitzek 2003; Torres 2004; } \\
\text { Zuniga 2004). Overall the NNT for at least 50\% pain relief over 4 to 6 } \\
\text { hours was not changed, but the potassium salt was significantly better } \\
\text { than the sodium salt }\end{array}$ \\
\hline 26 September 2008 & $\begin{array}{l}\text { New search has been } \\
\text { performed }\end{array}$ & $\begin{array}{l}\text { New studies added, analyses updated, additional data on use of rescue } \\
\text { medication, and new authors }\end{array}$ \\
\hline 22 May 2008 & Amended & Converted to new review format. \\
\hline
\end{tabular}

\section{WHAT'S NEW}

Last assessed as up-to-date: 14 September 2011.

\begin{tabular}{lll}
\hline Date & Event & Description \\
\hline 15 September 2011 & $\begin{array}{l}\text { Review declared as } \\
\text { stable }\end{array}$ & $\begin{array}{l}\text { The authors of this review scanned the literature in August 2011 and are } \\
\text { confident that there should be no need to update this review until 2015 }\end{array}$ \\
\hline
\end{tabular}

\section{References to studies included in this review}

Ahlstrom 1993 \{published data only\} . Ahlstrom U, Bakshi R, Nilsson P, Wahlander L. The analgesic efficacy of diclofenac dispersible and ibuprofen in postoperative pain after dental extraction. European Journal of Clinical Pharmacology. 1993; 44(6):587-8. [PubMed: 8405018]

Bakshi 1992 \{published data only\} . Bakshi R, Jacobs LD, Lehnert S, Picha B, Reuther J. A double-blind, placebo controlled trial comparing the analgesic efficacy of two formulations of diclofenac in postoperative dental pain. Current Therapeutic Research. 1992; 52(3):435-42.

Bakshi 1994 \{published data only\} . Bakshi R, Frenkel G, Dietlein G, Meurer Witt B, Schneider B, Sinterhauf U. A placebo-controlled comparative evaluation of diclofenac dispersible versus ibuprofen in postoperative pain after third molar surgery. Journal of Clinical Pharmacology. 1994; 34(3):225-30. [PubMed: 8021330]

Chang 2002 \{published data only\} . Chang DJ, Desjardins PJ, Chen E, Polis AB, McAvoy M, Mockoviak SH, et al. Comparison of the analgesic efficacy of rofecoxib and enteric-coated diclofenac sodium in the treatment of postoperative dental pain: a randomized, placebocontrolled clinical trial. Clinical Therapeutics. 2002; 24(4):490-503. [PubMed: 12017395]

Cooper 1996 \{published data only\} . Cooper SA, Cowan A, Tallarida RJ, Hargreaves K, Roszkowski M, Jamali F, et al. The analgesic interaction of misoprostol with nonsteroidal antiinflammatory drugs. American Journal of Therapeutics. 1996; 3(4):261-7. [PubMed: 11862259]

Desjardins 2004 \{published data only\} . Desjardins PJ, Black PM, Daniels S, Bird SR, Fitzgerald BJ, Petruschke RA, et al. A randomized controlled study comparing rofecoxib, diclofenac sodium, and placebo in post-bunionectomy pain. Current Medical Research and Opinion. 2004; 20(10):1523-37. [PubMed: 15462686]

Herbertson 1995 \{published data only\}. Herbertson RM, Storey N. The comparative efficacy of diclofenac potassium, aspirin and placebo in the treatment of patients with pain following gynecologic surgery. Todays Therapeutic Trends. 1995; 12(Suppl 1):33-45. 
Hersh 2004 \{published data only\} . Hersh EV, Levin LM, Adamson D, Christensen S, Kiersch TA, Noveck R, et al. Dose-ranging analgesic study of Prosorb diclofenac potassium in postsurgical dental pain. Clinical Therapeutics. 2004; 26(8):1215-27. [DOI: 10.1016/ S0149-2918(04)80033X]. [PubMed: 15476903]

Hofele 2006 \{published data only\} . Hofele CM, Gyenes V, Daems LN, Stypula-Ciuba B, Wagener $\mathrm{H}$, et al. Efficacy and tolerability of diclofenac potassium sachets in acute postoperative dental pain: a placebo-controlled, randomised, comparative study vs. diclofenac potassium tablets. International Journal of Clinical Practice. 2006; 60(3):300-7. [DOI: 10.1111/ j. 1368-5031.2006.00828.x]. [PubMed: 16494645]

Kubitzek 2003 \{published data only\} . Kubitzek F, Ziegler G, Gold MS, Liu JM, Ionescu E. Analgesic efficacy of low-dose diclofenac versus paracetamol and placebo in postoperative dental pain. Journal of Orofacial Pain. 2003; 17(3):237-44. [PubMed: 14520769]

Mehlisch 1995 \{published data only\} . Mehlisch DR, Brown P. Single-dose therapy with diclofenac potassium, aspirin or placebo following dental impaction surgery. Todays Therapeutic Trends. 1995; 12(Suppl 1):15-31.

Nelson 1994 \{published data only\} . Nelson SL, Brahim JS, Korn SH, Greene SS, Suchower LJ. Comparison of single-dose ibuprofen lysine, acetylsalicylic acid, and placebo for moderate-tosevere postoperative dental pain. Clinical Therapeutics. 1994; 16(3):458-65. [PubMed: 7923312]

Olson 1997 \{published data only\}. Olson NZ, Sunshine A, Zighelboim I, DeCastro A. Onset and duration of analgesia of diclofenac potassium in the treatment of postepisiotomy pain. American Journal of Therapeutics. 1997; 4:239-46. [PubMed: 10423616]

Torres 2004 \{published data only\} . Torres LM, Cabrera J, MartÍnez J, Calderón E, Fernández S, Chaves J. The specific cox-2 inhibitor valdecoxib provides effective analgesia after inguinal hernia surgery. Revista Espanola Anestesiologia y Reanimacion. 2004; 51(10):576-82.

Zuniga 2004 \{published data only\}. Zuniga JR, Phillips CL, Shugars D, Lyon JA, Peroutka SJ, Swarbrick J, et al. Analgesic safety and efficacy of diclofenac sodium softgels on postoperative third molar extraction pain. Journal of Oral Maxillofacial Surgery. 2004; 62(7):806-15. [DOI: 10.1016/j.joms.2003.12.019]. [PubMed: 15218558]

\section{References to studies excluded from this review}

Ahlstrom 1989 \{published data only\} . Ahlstrom U, Wahlander LA. Double-blind comparison of two different dosage recommendations for pain after surgical removal of a lower wisdom tooth. Current Therapeutic Research. 1989; 45(3):495-501.

Apaydin 1994 \{published data only\} . Apaydin A, Ozyuvaci H, Ordulu M, Disci R. Postoperative pain relief by single dose diclofenac kalium and etodolac. A comparative clinical study. The Journal of The Turkish Society of Algology. 1994; 6(4):28-34.

Aranda 1989 \{published data only\}. Aranda B, Bor YM. Comparative study between the efficacy of aluminum acetotartrate poultice and diclofenac in the postoperative treatment of degenerative knees [Etude du cataplasme d'acetotartrate d'alumine versus diclofenac dans le traitmente postoperatoire des genoux degeneratifs]. Comptes Rendus de Thérapeutique et de Pharmacologie Clinique. 1989; 7(80):11-7.

Carlos 1984 \{published data only\} . Carlos DE. Comparative study of the efficacy of diclofenac NA, meperidine HCL and nalbuphine HCL in postoperative analgesia. Philippine Journal of Internal Medicine. 1984; 22(1):51-5.

Dorfmann 1991 \{published data only\} . Dorfmann H. Controlled therapeutic trial of diclofenac in meniscectomy under arthroscopy [Essai therapeutique controle du diclofenac dans les meniscectomies sous arthroscopie]. Revue du Rhumatisme et des Maladies Osteo-Articulaires. 1991; 58(1):59-61. [PubMed: 1871522]

El-Tanany 1993 \{published data only . El-Tanany H, Boghdady W. A double blind comparative study of Diclofenac-K and Glafenine in the management of acute dental pain. Cairo Dental Journal. 1993; 9(2):117-20.

Fineschi 1997 \{published data only\} . Fineschi G, Tamburrelli FC, Francucci BM, Pisati R. Oral diclofenac dispersible provides a faster onset of analgesia than intramuscular ketorolac in the treatment of postoperative pain. Clinical Drug Investigation. 1997; 13:1-7. 
Frezza 1985 \{published data only\} . Frezza R, Bolognesi P, Bernardi F. Comparison of the action of 3 non-steroidal anti-inflammatory agents in the control of post-operative pain. Effectiveness of NSAID against pain [Confronto sull'azione di tre antinfiammatori non steroidei nel controllo de dolore odontoiatrico post-chirurgico. Efficaci i FANS contro il dolore]. Attualita Dentale. 1985; 1(30):40-2. [PubMed: 3869471]

Garcia 1997 \{published data only\} . Garcia DC, Espinosa JD, Marti ML. Analgesic efficacy of both lisine clonixinate and diclofenac for postsurgical pain during ambulatory surgery. Prensa Medica Argentina. 1997; 84:1061-5.

Graf 2000 \{published data only\}. Graf von Ingelheim FA. A homeopathic drug is equivalent to diclofenac? Der Orthopade. 2000; 29:596. [PubMed: 10929340]

Henderson 1994 \{published data only\} . Henderson RC. A double-blind comparison of diclofenac potassium and naproxen sodium in the treatment of pain due to orthopedic skeletal surgery. Todays Therapeutic Trends. 1994; 12(S1):81-95.

Henrikson 1982 \{published data only\} . Henrikson PA, Thilander H, Wahlander LA. Absorption and effect of diclofenac-sodium after surgical removal of a lower wisdom tooth. Current Therapeutic Research. 1982; 31(1):20-6.

Hultin 1978 \{published data only\} . Hultin M, Olander KJ. A clinical trial of the analgesic properties of Voltaren (diclofenac sodium). Scandinavian Journal of Rheumatology. Supplement. 1978; 22:42-5. [PubMed: 356244]

Iqbal 1986 \{published data only\} . Iqbal KM, Biswas GK, Mondo SK, Afzalunnessa B. Assessment of post operative analgesia: A comparative study of pethidine and diclofenac sodium. Journal of Bangladesh College of Physicians and Surgeons. 1986; 4(1):1-7.

Iwabuchi 1980 \{published data only\} . Iwabuchi T, Soma S. Use of Voltaren for relief of postextraction pain. Shikai Tenbo [Dental Outlook]. 1980; 55(2):367-70.

Joubert 1977 \{published data only . Joubert JJ. An assessment of the efficacy and tolerability of Voltaren in the treatment of inflammation after extractionof teeth. Journal of the Dental Association of South Africa. 1977; 32:581-3. [PubMed: 277449]

Kittala 1972 \{published data only\} . Kittala S, Aizawa M, Tokue I, Suge Y. Efficacy of GP-45840 on after-pains. Clinical trial with double blind method. Shinryo To Shinyaku [Medical Consultation and New Remedies]. 1972; 9(6):1123.

Li 1998 \{published data only\} . Li X, Wu XC, Zhao LL. Randomised controlled study of the effect of diclofenac potassium and keflan. Chinese Journal of Pharmacoepidemiology. 1998; 7:69-71.

Matthews 1984 \{published data only\} . Matthews RW, Scully CM, Levers BG. The efficacy of diclofenac sodium (Voltarol) with and without paracetamol in the control of post surgical dental pain. British Dental Journal. 1984; 157(10):357-9. [PubMed: 6394041]

Mayer 1980 \{published data only\} . Mayer M, Weiss P. Antiphlogistic and analgesic effect of diclofenac sodium after maxillofacial interventions in a double-blind trial [Uber die antiphlogistische und analgetische Wirkung von Diclofenac-Na nach kieferchirurgischen Eingriffen im Doppelblindversuch]. Deutsche Zahnarztliche Zeitschrift. 1980; 35(5):559-63. [PubMed: 7004845]

Nakanishi 1990 \{published data only\} . Nakanishi M, Mizukawa N, Koyama S, Takagi S, Nishijima K. Clinical evaluation of Amfenac sodium compared with Diclofenac sodium. Journal of Oral Therapeutics and Pharmacology. 1990; 9(2):85-92.

Rautela 1998 \{published data only\} . Rautela RS, Kumar A, Gupta A, Bhattacharya A. A randomised double blind comparison of ketorolac and diclofenac for post-operative analgesia following major gynaecological surgery. Journal of Anesthesiology Clinical Pharmacology. 1998; 14:79-81.

Shimura 1981 \{published data only\} . Shimura T, Otaka Y, Ando N, Nagao H. Voltaren tablets for the pain following tooth extraction - studies of its analgesic effects. Shikai Tenbo [Dental Outlook]. 1981; 58(1):175-83.

Tam 2001 \{published data only\} . Tam WH, Yuen PM. Use of diclofenac as an analgesic in outpatient hysteroscopy: a randomized, double-blind, placebo-controlled study. Fertility and Sterility. 2001; 76(5):1070-2. [PubMed: 11704141] 
Tani 1974 \{published data only\} . Tani I. Therapeutic results of Voltaren tablets an analgesic antiinflammatory agent in pain following tonsillectomy. Shinryo To Shinyaku [Medical Consultation and New Remedies]. 1974; 11(8):274.

Tesseroli 1986 \{published data only\} . Tesseroli de Siqueira JT, Potenza BJ, Basta D. Evaluation of the analgesic efficacy of potassium diclofenac and placebo in postoperative treatment of dental surgery. Multicentre, double blind study [Avaliacao do eficacia analgesicado diclofenaco potassico e placebo no pos-operatorio de cirurgias para extracoes dentarias. Estudo multicentrico, dupl-cego]. Revista Paulista de Odontologia. 1986; 6:2-7.

Ujpal 1999 \{published data only\} . Ujpal M, Biczo A, Huszar L, Temesvari A, Tothfalusi L, Szabo G. Comparative study of the analgesic effect of apranax and cataflam after oral surgery procedures [Az apranax es a cataflam fajdalomesillapito hatasanak osszehasonlito vizsgalata szajsebeszeti beavatkozast kovetoen]. Fogorvosi Szemle. 1999; 92(12):374-8. [PubMed: 10641420]

Vigneron 1977 \{published data only\} . Vigneron JR, Thys R. Study of the anti-inflammatory and analgesic actions of diclofenac in traumatology and orthopedic surgery [Etude de l'action antiinflammatoire et antalgique du diclofenac en traumatologie et chirurgie orthopedique]. Revue Medicale de Liege. 1977; 32(1):10-4. [PubMed: 834928]

Walton 1993 \{published data only\} . Walton GM, Rood JP, Snowdon AT, Rickwood D. Ketorolac and diclofenac for postoperative pain relief following oral surgery. British Journal of Oral Maxillofacial Surgery. 1993; 31(3):158-60. [PubMed: 8512909]

Wuolijoki 1987 \{published data only\} . Wuolijoki E, Oikarinen VJ, Ylipaavalniemi P, Hampf G, Tolvanen M. Effective postoperative pain control by preoperative injection of diclofenac. European Journal of Clinical Pharmacology. 1987; 32(3):249-52. [PubMed: 3595697]

Zhang 2000 \{published data only\} . Zhang SL, Meng ZY, Xu JH, Shou BQ. Analgesic efficacy of diclofenac potassium in dental pain trial. Journal of Medical Postgraduate. 2000; 13:24-5.

\section{Additional references}

Barden 2004b . Barden J, Edwards J, Moore RA, McQuay HJ. Single dose oral rofecoxib for postoperative pain. Cochrane Database of Systematic Reviews. 2004; (Issue 4) [DOI: 10.1002/ 14651858.CD004604.pub2].

BNF 2002 . Mehta, DK., editor. British National Formulary. Vol. 43. Vol. British Medical Journal; London: Mar. 2002 Non-steroidal anti-inflammatory drugs; p. 482

Collins 1997 . Collins SL, Moore RA, McQuay HJ. The visual analogue pain intensity scale: what is moderate pain in millimetres? Pain. 1997; 72:95-7. [PubMed: 9272792]

Collins 1999 . Collins SL, Moore RA, McQuay HJ, Wiffen PJ, Edwards JE. Single dose oral ibuprofen and diclofenac for postoperative pain. Cochrane Database of Systematic Reviews. 1999; (Issue 2) [DOI: 10.1002/14651858.CD001548].

Collins 2001 . Collins SL, Edwards JE, Moore RA, Smith LA, McQuay HJ. Seeking a simple measure of analgesia for mega-trials: is a single global assessment good enough? Pain. 2001; 91(1-2):189-94. [PubMed: 11240091]

Cook 1995 . Cook RJ, Sackett DL. The number needed to treat: a clinically useful measure of treatment effect. British Medical Journal. 1995; 310:452-4. [PubMed: 7873954]

Cooper 1991 . Cooper, SA. Single-dose analgesic studies: the upside and downside of assay sensitivity. In: Max, MB.; Portenoy, RK.; Laska, EM., editors. The design of analgesic clinical trials. Advances in Pain Research and Therapy. Vol. Vol. 18. Raven Press; New York: 1991. p. 117-24.

Derry 2008 . Derry S, Moore RA, McQuay HJ. Single dose oral celecoxib for acute postoperative pain. Cochrane Database of Systematic Reviews. 2008; (Issue 4) [DOI: 10.1002/ 14651858.CD004233].

Derry 2009 . Derry C, Derry S, Moore RA, McQuay HJ. Single dose oral naproxen and naproxen sodium for acute postoperative pain in adults. Cochrane Database of Systematic Reviews. 2009; (Issue 1) [Art. No.: CD004234. DOI: 10.1002/ 14651858.CD004234.pub3]. 
Desjardins 2004 . Desjardins PJ, Black PM, Daniels S, Bird SR, Fitzgerald BJ, Petruschke RA, et al. A randomized controlled study comparing rofecoxib, diclofenac sodium, and placebo in postbunionectomy pain. Current Medical Research and Opinion. 2004; 20(10):1523-37. [PubMed: 15462686]

Edwards 1999 . Edwards JE, McQuay HJ, Moore RA, Collins SL. Reporting of adverse effects in clinical trials should be improved. Lessons from acute postoperative pain. Journal of Pain and Symptom Management 1999. 1999; 18:427-37.

Fitzgerald 2001 . FitzGerald GA, Patrono C. The coxibs, selective inhibitors of cyclooxygenase- 2. New England Journal of Medicine. 2001; 345(6):433-42. [PubMed: 11496855]

Forrest 2002 . Forrest JB, Camu F, Greer IA, Kehlet H, Abdalla M, Bonnet F. Ketorolac, diclofenac, and ketoprofen are equally safe for pain relief after major surgery. British Journal of Anaesthesia. 2002; 88(2):227-33. [PubMed: 11883386]

Grahame-Smith 2002 . Grahame-Smith, DG.; Aronson, JK. Oxford textbook of clinical pharmacology and drug therapy. 3rd Edition. Oxford University Press; Oxford: 2002. [ISBN: 13: 978-0-19-263234-0]

Hawkey 1999 . Hawkey CJ. Cox-2 inhibitors. Lancet. 1999; 353(9149):307-14. [PubMed: 9929039]

Hernández-Díaz 2001 . Hernández-Díaz S, García-Rodríguez LA. Epidemiologic assessment of the safety of conventional nonsteroidal anti-inflammatory drugs. American Journal of Medicine. 2001; 110(Suppl 3A):20S-7S. [DOI: 110.1016/S0002-9343 (00)00682-3]. [PubMed: 11173046]

Jadad 1996a . Jadad AR, Carroll D, Moore A, McQuay H. Developing a database of published reports of randomised clinical trials in pain research. Pain. 1996; 66:239-46. [PubMed: 8880846]

Jadad 1996b . Jadad AR, Moore RA, Carroll D, Jenkinson C, Reynolds DJM, Gavaghan DJ, McQuay HJ. Assessing the quality of reports of randomized clinical trials: is blinding necessary? Controlled Clinical Trials. 1996; 17:1-12. [PubMed: 8721797]

L'Abbé 1987 . L'Abbé KA, Detsky AS, O'Rourke K. Meta-analysis in clinical research. Annals of Internal Medicine. 1987; 107:224-33. [PubMed: 3300460]

Martindale 1996 . Reynolds, JEF.; Parfitt, K.; Parsons, AV.; Sweetman, SC., editors. Martindale: The extra pharmacopoeia. Vol. 31. Royal Pharmaceutical Society; London: 1996. Analgesics Anti-inflammatory Agents and Antipyretics; p. 36[ISBN: 0-85369-342-0]

McQuay 1982 . McQuay HJ, Bullingham RE, Moore RA, Evans PJ, Lloyd JW. Some patients don't need analgesics after surgery. Journal of the Royal Society of Medicine. 1982; 75(9):705-8. [PubMed: 7120254]

McQuay 2005 . McQuay HJ, Moore RA. Placebo. Postgraduate Medical Journal. 2005; 81:155-60. [PubMed: 15749790]

Moher 1999 . Moher D, Cook DJ, Eastwood S, Olkin I, Rennie D, Stroup DF. Improving the quality of meta-analyses of randomised controlled trials: the QUOROM statement. The Lancet. 1999; 354:1896-900.

Moore 1996 . Moore A, McQuay H, Gavaghan D. Deriving dichotomous outcome measures from continuous data in randomised controlled trials of analgesics. Pain. 1996; 66(2-3):229-37. [PubMed: 8880845]

Moore 1997a . Moore A, McQuay H, Gavaghan D. Deriving dichotomous outcome measures from continuous data in randomised controlled trials of analgesics: verification from independent data. Pain. 1997; 69(1-2):127-30. [PubMed: 9060022]

Moore 1997b . Moore A, Moore O, McQuay H, Gavaghan D. Deriving dichotomous outcome measures from continuous data in randomised controlled trials of analgesics: Use of pain intensity and visual analogue scales. Pain. 1997; 69(3):311-5. [PubMed: 9085306]

Moore 1998 . Moore RA, Carroll D, Wiffen PJ, Tramer M, McQuay HJ. A systematic review of topically-applied non-steroidal anti-inflammatory drugs. BMJ. 1998; 316:333-8. [PubMed: 9487165]

Moore 2003 . Moore, RA.; Edwards, J.; Barden, J.; McQuay, HJ. Bandolier's Little Book of Pain. Oxford University Press; Oxford: 2003.

Moore 2005 . Moore RA, Edwards JE, McQuay HJ. Acute pain: individual patient meta-analysis shows the impact ofdifferent ways of analysing and presenting results. Pain. 2005; 116(3):32231. [DOI: 10.1016/j.pain.2005.05.001]. [PubMed: 15979792] 
Morris 1995 . Morris, JA.; Gardner, MJ. Calculating confidence intervals for relative risk, odds ratio and standardised ratios and rates. In: Gardner, MJ.; Altman, DG., editors. Statistics with confidence - confidence intervals and statistical guidelines. British Medical Journal; London: 1995. p. 50-63.

Oldman 2000 . Oldman A, Smith LA, Collins S, Carroll D, Wiffen PJ, McQuay HJ, et al. Single dose oral aspirin for acute pain. Cochrane Database of Systematic Reviews. 2000; (Issue 2) [DOI: 10.1002/14651858.CD002067].

PACT 2007 . Prescription Cost Analysis. England: 2007. [ISBN: 978-1-84636-210-1]

Rapoport 1999 . Rapoport RJ. The Safety of NSAIDs and Related Drugs for the Management of Acute Pain: Maximizing Benefits and Minimizing Risks. Cancer Control. 1999; 6(2 Suppl 1):1821. [PubMed: 12118235]

Roy 2007 . Roy YM, Derry S, Moore RA. Single dose oral lumiracoxib for postoperative pain. Cochrane Database of Systematic Reviews. 2007; (Issue 4) [DOI: 10.1002/ 14651858.CD006865].

Toms 2008 . Toms L, McQuay HJ, Derry S, Moore RA. Single dose oral paracetamol (acetaminophen) for postoperative pain in adults. Cochrane Database of Systematic Reviews. 2008; (Issue 4) [DOI: 10.1002/14651858.CD004602].

Tramèr 1997 . Tramèr MR, Reynolds DJM, Moore RA, McQuay HJ. Impact of covert duplicate results on meta-analysis: a case study. BMJ. 1997; 315:635-9. [PubMed: 9310564]

\section{References to other published versions of this review}

Barden 2004a . Barden J, Edwards J, Moore RA, McQuay HJ. Single dose oral diclofenac for postoperative pain. Cochrane Database of Systematic Reviews. 2004; (Issue 2) [DOI: 10.1002/ 14651858.CD004768].

Collins 1998 . Collins SL, Moore RA, McQuay HJ, Wiffen PJ. Oral ibuprofen and diclofenac in postoperative pain: a quantitative systematic review. European Journal of Pain. 1998; 2(4):28591. [PubMed: 10700324]

* Indicates the major publication for the study 


\section{PLAIN LANGUAGE SUMMARY}

Single dose oral diclofenac for pain relief in adults experiencing moderate or severe pain following a surgical procedure

Diclofenac is a non-steroidal anti-inflammatory drug (NSAID) with pain relieving properties. It is used to treat many painful conditions, including acute postoperative pain. This review shows that single dose oral diclofenac provides effective pain relief for adults experiencing moderate or severe pain following a surgical procedure. For every five participants with moderate to severe postoperative pain treated with a single dose of diclofenac, two would experience at least $50 \%$ pain relief who would not have done so with placebo. One form of diclofenac, the potassium salt, is more effective at the same dose than the other form of diclofenac, the sodium salt. The incidence of adverse effects did not differ significantly from placebo in these single dose studies. 


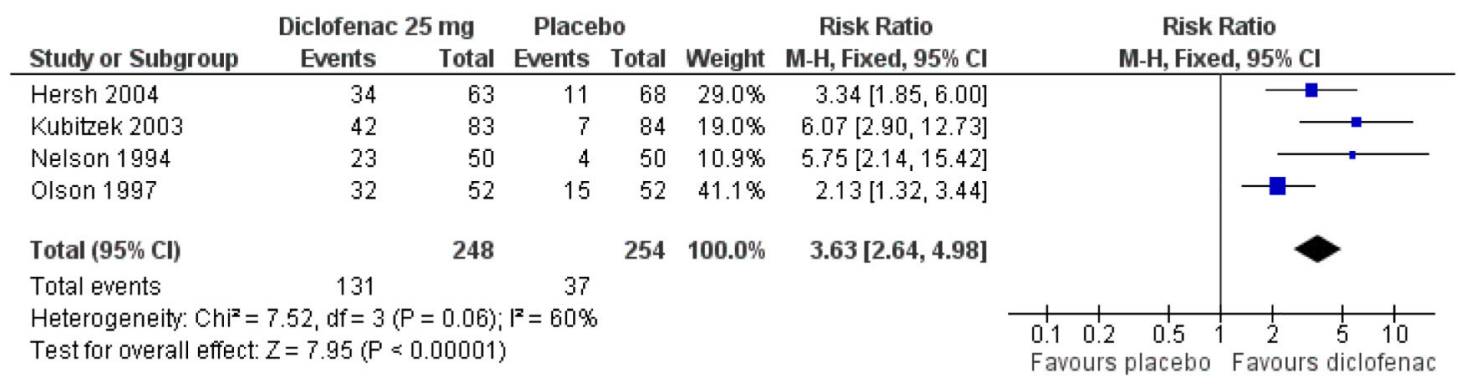

Figure 1.

Forest plot of comparison: 1 Diclofenac $25 \mathrm{mg}$ v placebo, outcome: 1.1 Participants with at least $50 \%$ pain relief over 4 to 6 hours. 


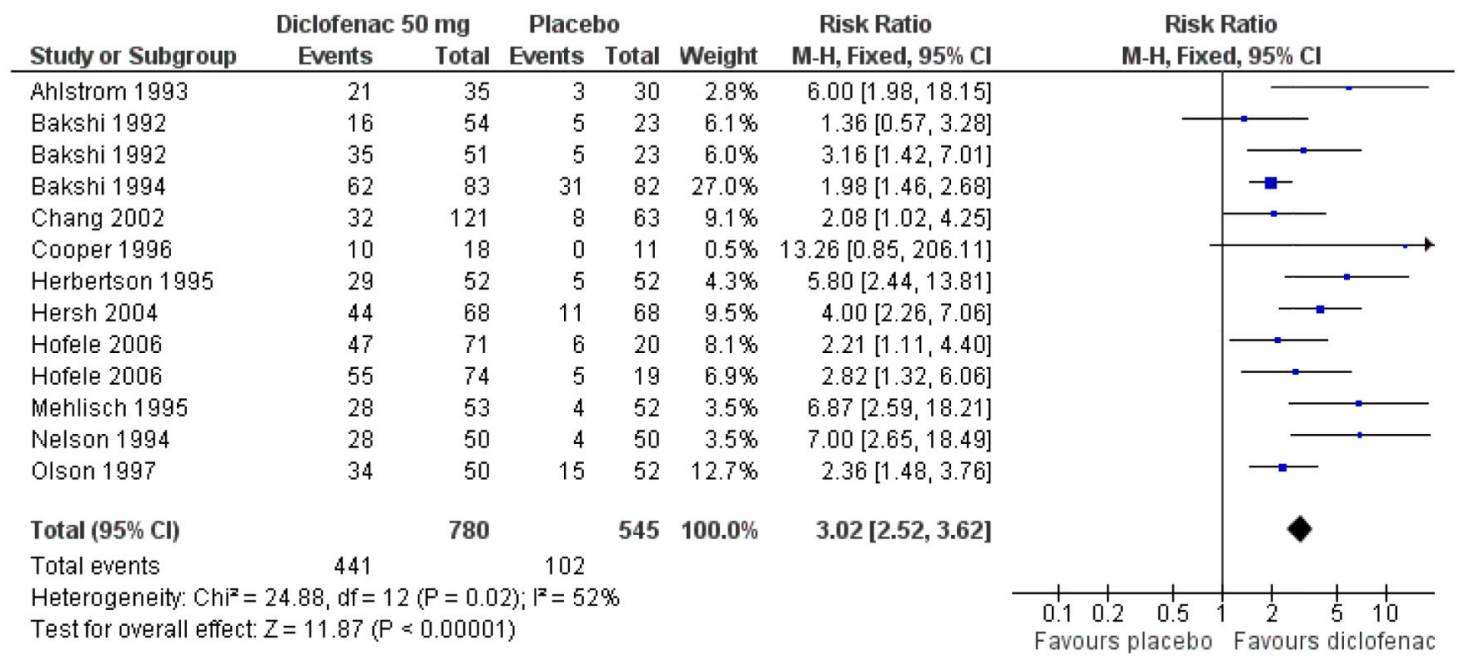

Figure 2.

Forest plot of comparison: 2 Diclofenac $50 \mathrm{mg}$ v placebo, outcome: 2.1 Participants with at least $50 \%$ pain relief over 4 to 6 hours. 


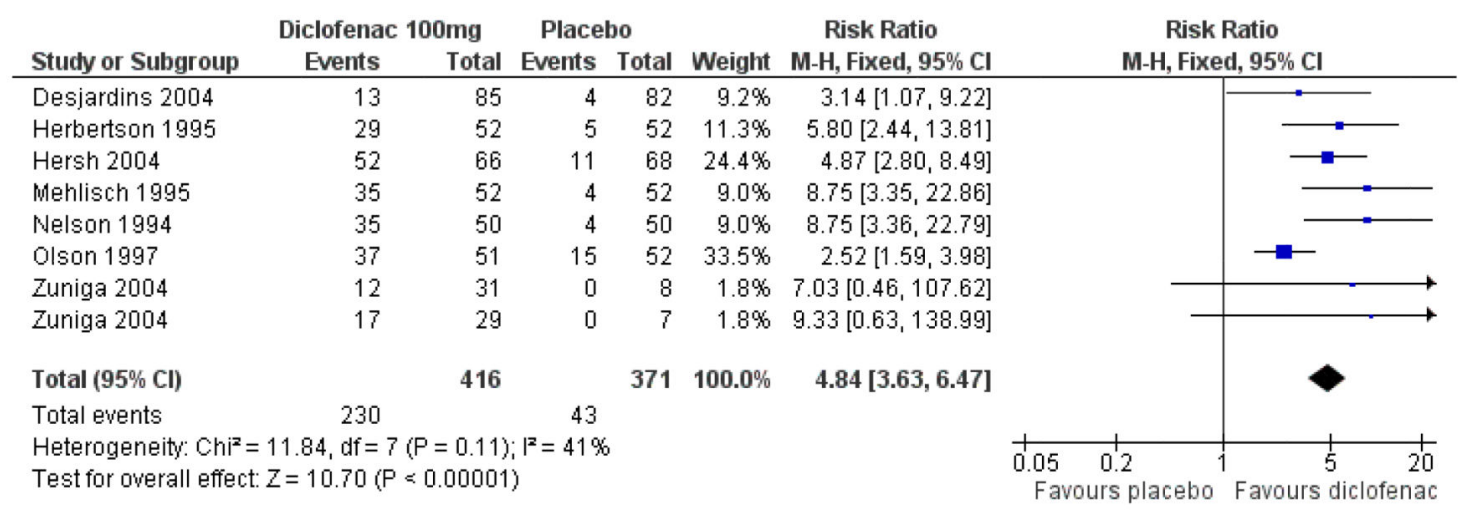

Figure 3.

Forest plot of comparison: 3 Diclofenac $100 \mathrm{mg}$ v placebo, outcome: 3.1 Participants with at least $50 \%$ pain relief over 4 to 6 hours. 


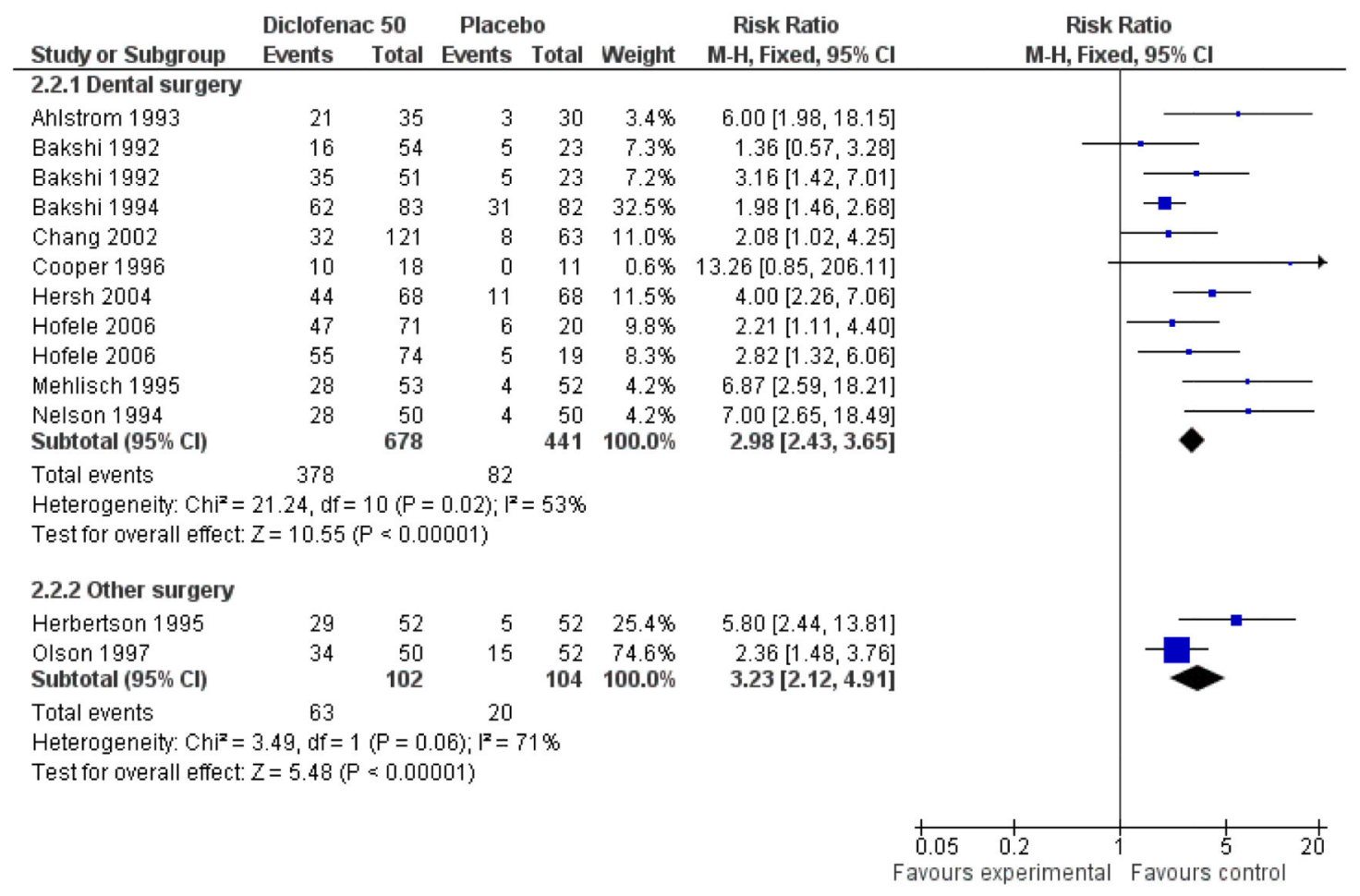

Figure 4.

Forest plot of comparison: 2 Diclofenac $50 \mathrm{mg}$ v placebo, outcome: 2.4 Participants with at least $50 \%$ pain relief over 4 to 6 hours, dental or other surgery. 


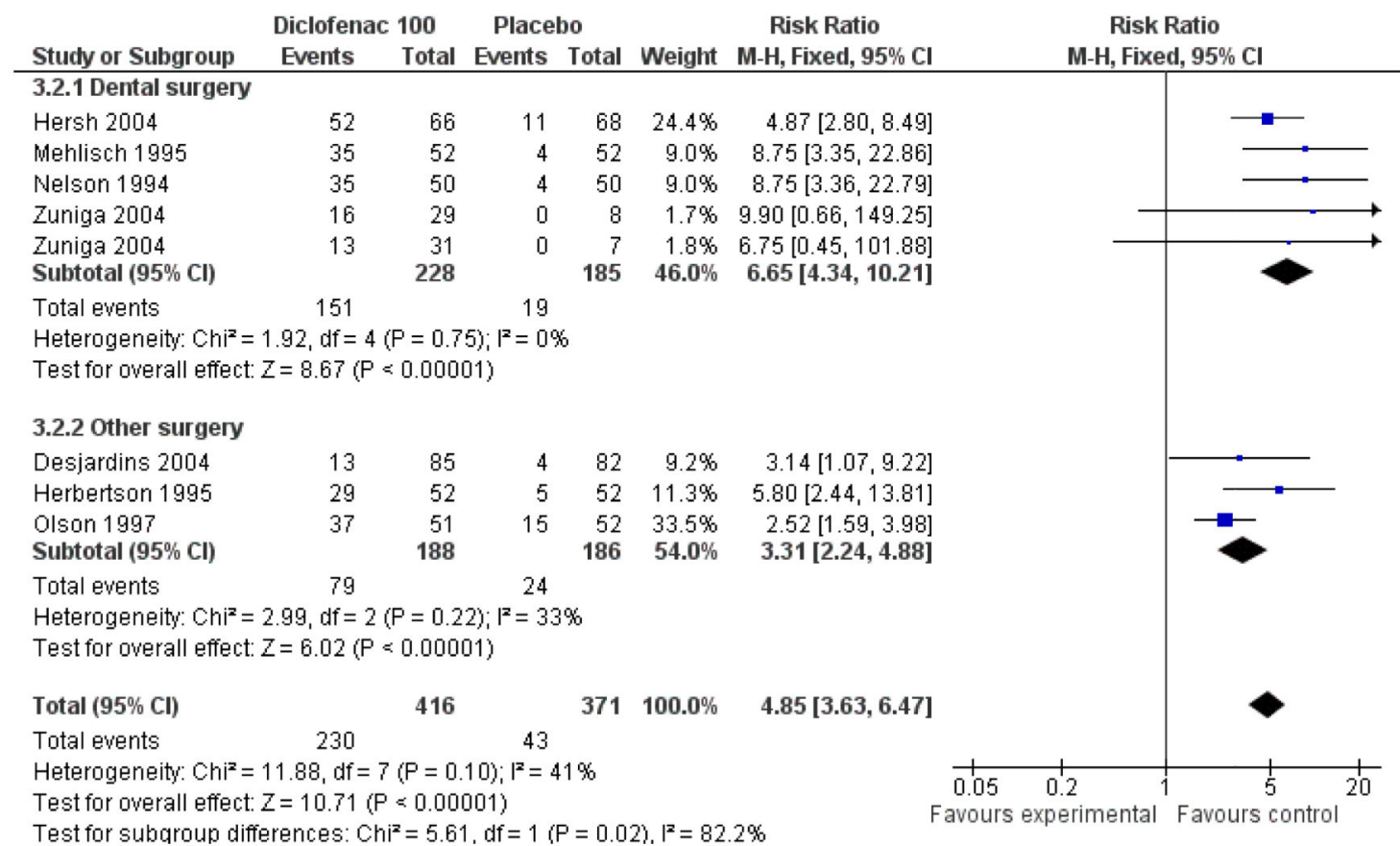

Figure 5.

Forest plot of comparison: 3 Diclofenac $100 \mathrm{mg}$ v placebo, outcome: 3.6 Participants with at least $50 \%$ pain relief over 4 to 6 hours, dental or other surgery. 


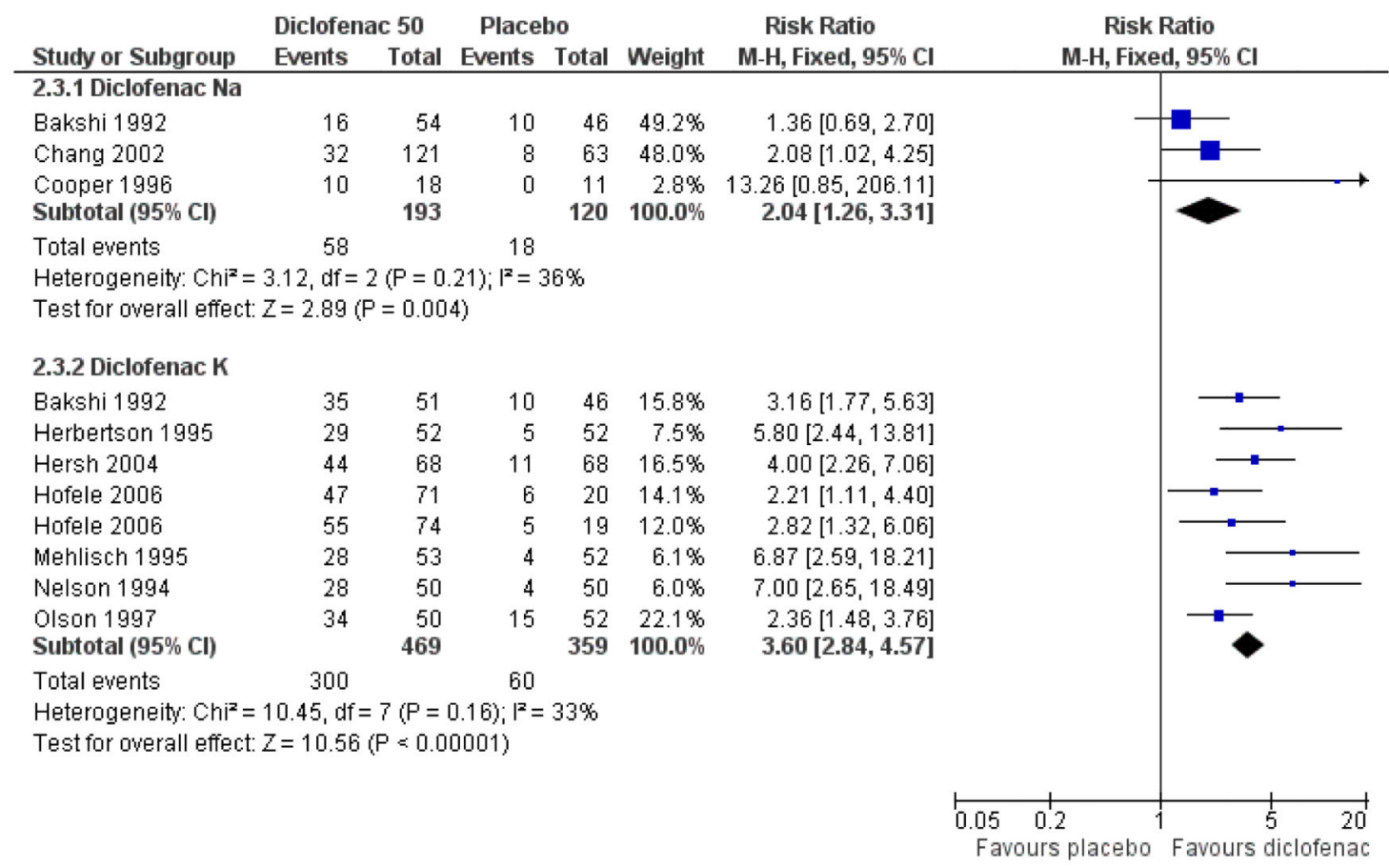

\section{Figure 6.}

Forest plot of comparison: 2 Diclofenac $50 \mathrm{mg}$ v placebo, outcome: 2.11 Participants with at least $50 \%$ pain relief over 4 to 6 hours, $\mathrm{Na}$ or $\mathrm{K}$ salt. 


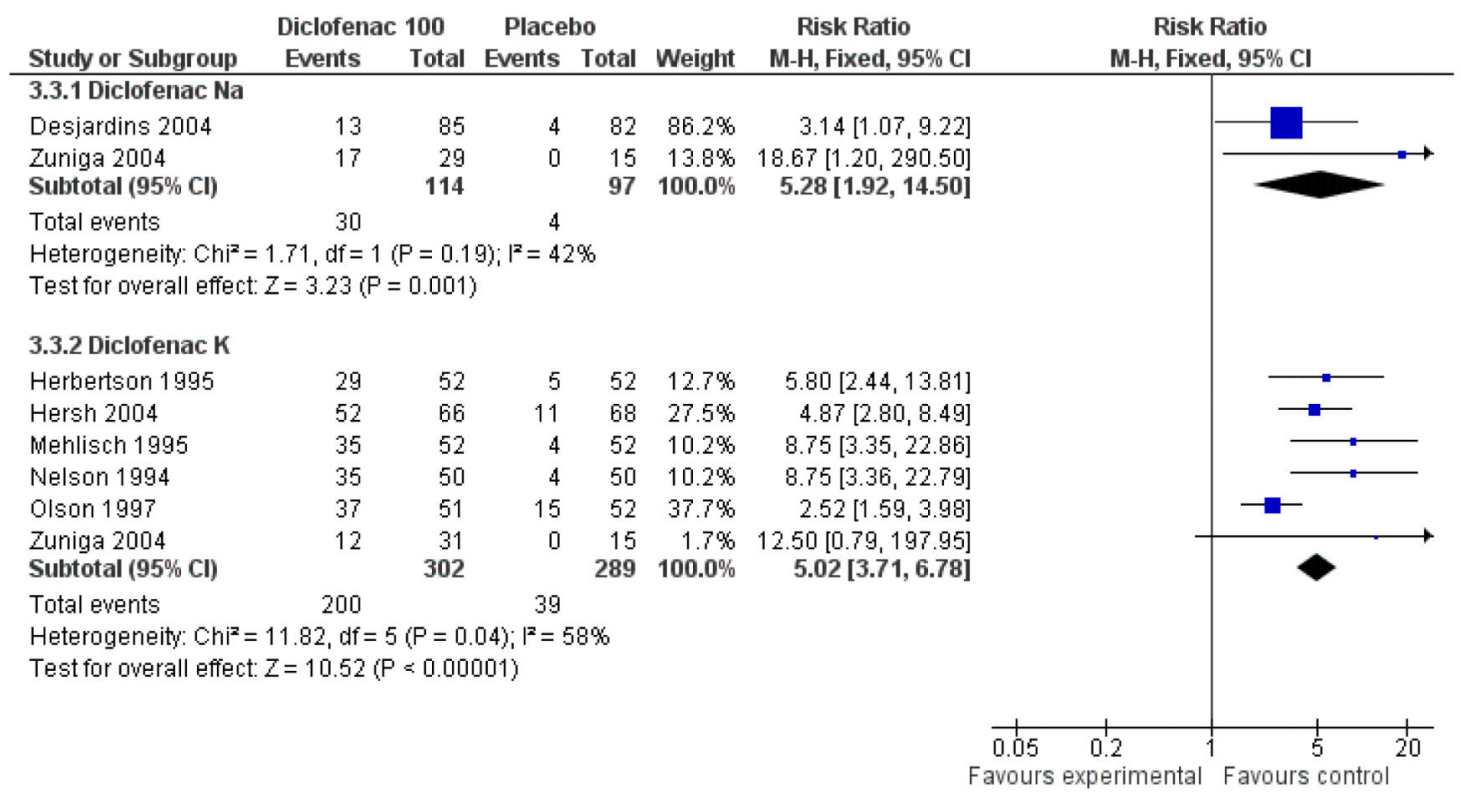

Figure 7.

Forest plot of comparison: 3 Diclofenac $100 \mathrm{mg}$ v placebo, outcome: 3.7 Participants with at least $50 \%$ pain relief over 4 to 6 hours, $\mathrm{Na}$ or $\mathrm{K}$ salt. 


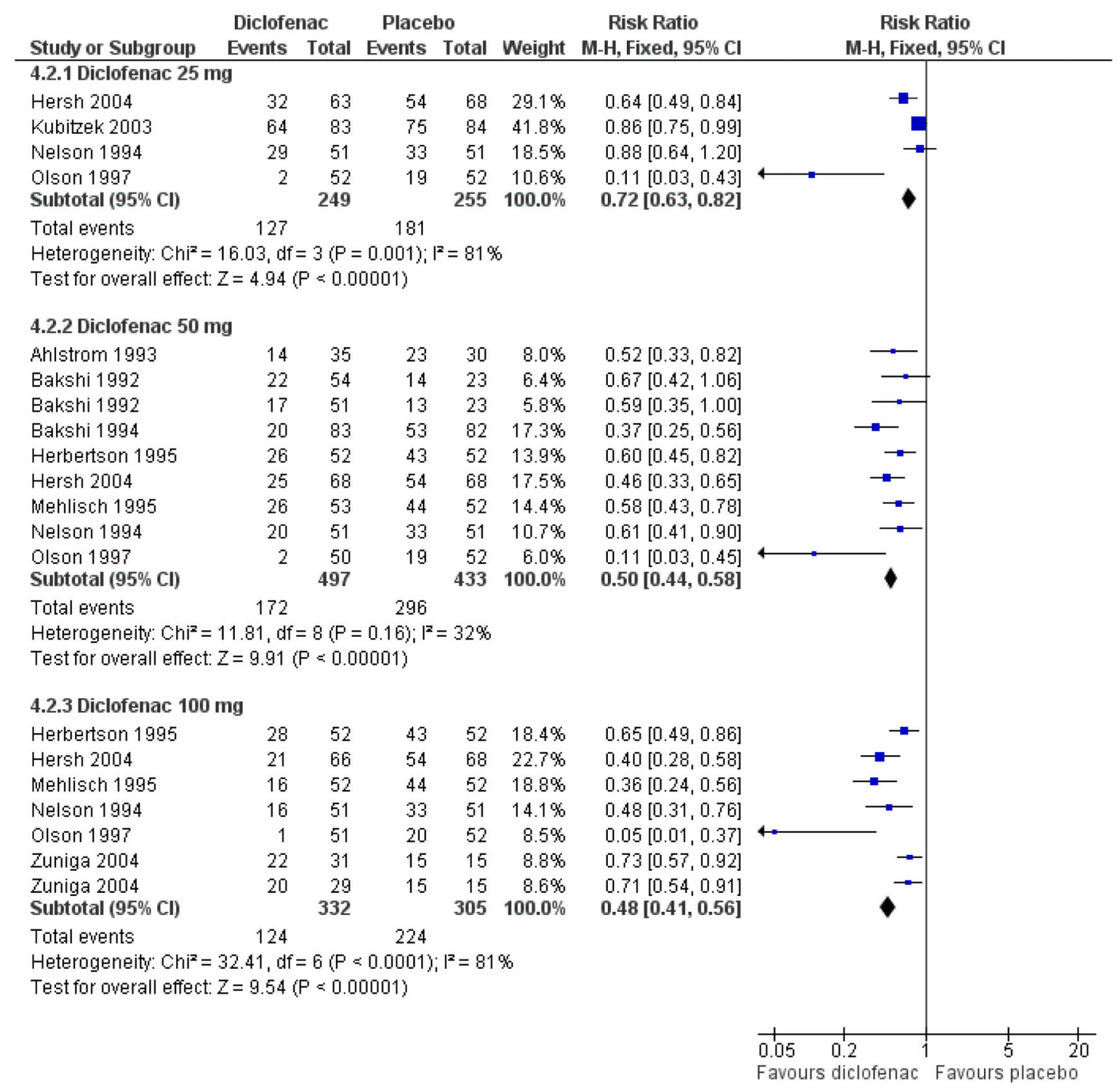

Figure 8.

Forest plot of comparison: 4 Diclofenac versus placebo, outcome: 4.2 Participants using rescue medication at 6 hours. 


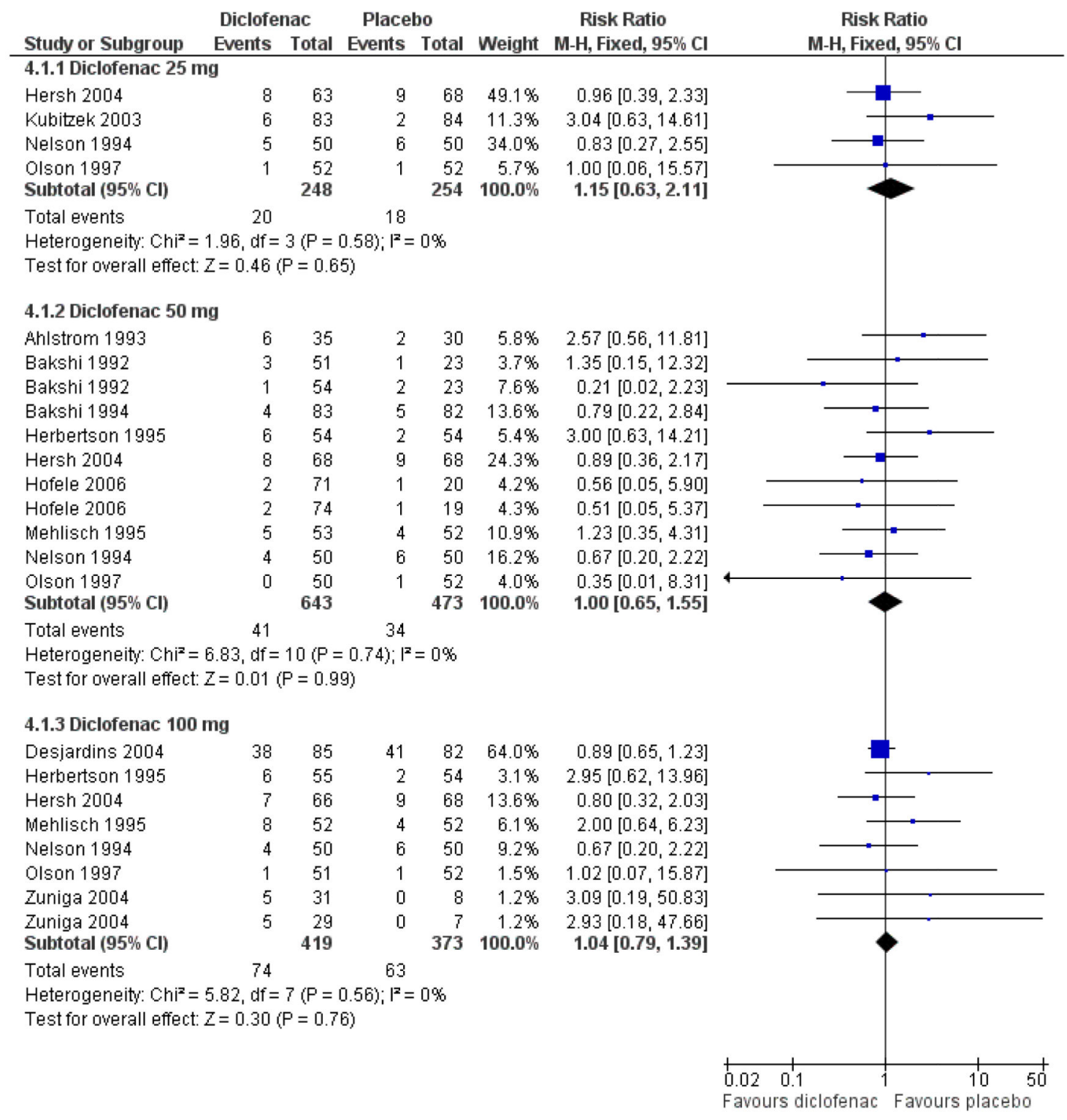

Figure 9.

Forest plot of comparison: 4 Diclofenac versus placebo, outcome: 4.1 Participants with at least one adverse event. 


\section{Table 1}

Summary of outcomes: analgesia and rescue medication

\begin{tabular}{|c|c|c|c|c|c|c|}
\hline \multirow[b]{2}{*}{ Study ID } & \multirow[b]{2}{*}{ Treatment } & \multicolumn{2}{|l|}{ Analgesia } & \multirow[b]{2}{*}{$\begin{array}{l}\text { PGR: v good or } \\
\text { excellent }\end{array}$} & \multicolumn{2}{|c|}{ Rescue medication } \\
\hline & & PI or PR & $\begin{array}{l}\text { Number } \\
\text { with } 50 \% \\
\text { PR }\end{array}$ & & $\begin{array}{l}\text { Median time to } \\
\text { use (hr) }\end{array}$ & $\%$ using \\
\hline Ahlstrom 1993 & $\begin{array}{l}\text { 1) Diclofenac (soluble) } 50 \mathrm{mg} \text {, } \\
\mathrm{n}=35 \\
\text { (2) Ibuprofen (tablets) } 400 \mathrm{mg} \text {, } \\
\mathrm{n}=32 \\
\text { (3) Placebo, } \mathrm{n}=30\end{array}$ & $\begin{array}{l}\text { TOTPAR 6: } \\
\text { (1) } 153 \mathrm{~mm} \\
\text { (3) } 292 \mathrm{~mm}\end{array}$ & $\begin{array}{l}\text { (1) } 21 / 35 \\
\text { (3) } 3 / 50\end{array}$ & $\begin{array}{l}\text { at } 6 \text { hours: } \\
\text { (1) } 23 / 35 \\
\text { (3) } 5 / 30\end{array}$ & no data & $\begin{array}{l}\text { at } 6 \text { hours: } \\
\text { (1) } 40 \\
\text { (3) } 77\end{array}$ \\
\hline Bakshi 1992 & $\begin{array}{l}\text { (1) Diclofenac K } 50 \mathrm{mg}, \mathrm{n}= \\
51 \\
\text { (2) Diclofenac } \mathrm{Na} \text { (enteric } \\
\text { coated) } 50 \mathrm{mg}, \mathrm{n}=54 \\
\text { (3) Placebo, } \mathrm{n}=46\end{array}$ & $\begin{array}{l}\text { TOTPAR 6: } \\
\text { (1) } 10 \\
\text { (2) } 7.3 \\
\text { (3) } 5.2\end{array}$ & $\begin{array}{l}\text { (1) } 35 / 51 \\
\text { (2) } 16 / 54 \\
\text { (3) } 10 / 46\end{array}$ & no usable data & no usable data & $\begin{array}{l}\text { at } 6 \text { hours: } \\
\text { (1) } 33 \\
\text { (2) } 41 \\
\text { (3) } 59\end{array}$ \\
\hline Bakshi 1994 & $\begin{array}{l}\text { (1) Diclofenac (soluble) } 50 \\
\text { mg, } \mathrm{n}=83 \\
\text { (2) Ibuprofen } 400 \mathrm{mg}, \mathrm{n}=80 \\
\text { (3) Placebo, } \mathrm{n}=82\end{array}$ & $\begin{array}{l}\text { TOTPAR 6: } \\
\text { (1) } 15.5 \\
\text { (3) } 8.9\end{array}$ & $\begin{array}{l}\text { (1) } 62 / 83 \\
\text { (3) } 31 / 82\end{array}$ & no usable data & $\begin{array}{l}\text { Mean: } \\
\text { (1) } 5.35 \\
\text { (3) } 3.36\end{array}$ & $\begin{array}{l}\text { at } 6 \text { hours: } \\
\text { (1) } 24 \\
\text { (3) } 65\end{array}$ \\
\hline Chang 2002 & $\begin{array}{l}\text { (1) Diclofenac Na (enteric } \\
\text { coated) } 50 \mathrm{mg}, \mathrm{n}=121 \\
\text { (2) Rofecoxib } 50 \mathrm{mg}, \mathrm{n}=121 \\
\text { (3) Placebo, } \mathrm{n}=63\end{array}$ & $\begin{array}{l}\text { TOTPAR 6: } \\
\text { (1) } 5.8 \\
\text { (3) } 4.3\end{array}$ & $\begin{array}{l}\text { (1) } 32 / 121 \\
\text { (3) } 8 / 63\end{array}$ & no usable data & $\begin{array}{l}\text { (1) } 1.62 \\
\text { (3) } 1.62\end{array}$ & $\begin{array}{l}\text { at } 8 \text { hours: } \\
\text { (1) } 67 \\
\text { (3) } 76\end{array}$ \\
\hline Cooper 1996 & $\begin{array}{l}\text { (1) Diclofenac Na } 50 \mathrm{mg}, \mathrm{n}= \\
18 \\
\text { (2) Misoprostol } 200 \mu \mathrm{g}, \mathrm{n}=21 \\
\text { (3) Diclofenac } \mathrm{Na}+ \\
\text { misoprostol } 50 \mathrm{mg} / 200 \mu \mathrm{g}, \mathrm{n}= \\
20 \\
\text { (4) Placebo, } \mathrm{n}=11\end{array}$ & $\begin{array}{l}\text { TOTPAR 6: } \\
\text { (1) } 12.5 \\
\text { (4) } 1.9\end{array}$ & $\begin{array}{l}\text { (1) } 10 / 18 \\
\text { (4) } 0 / 11\end{array}$ & no usable data & $\begin{array}{l}\text { Mean: } \\
\text { (1) } 4.68 \\
\text { (4) } 2.11\end{array}$ & no data \\
\hline Desjardins 2004 & $\begin{array}{l}\text { (1) Diclofenac Na } 100 \mathrm{mg}, \mathrm{n}= \\
85 \\
\text { (2) Rofecoxib } 50 \mathrm{mg}, \mathrm{n}=85 \\
\text { (3) Placebo, } \mathrm{n}=82\end{array}$ & $\begin{array}{l}\text { TOTPAR 6: } \\
\text { (1) } 4.8 \\
\text { (3) } 2.9\end{array}$ & $\begin{array}{l}\text { (1) } 13 / 85 \\
\text { (3) } 4 / 82\end{array}$ & $\begin{array}{l}\text { at } 8 \text { hours: } \\
\text { (1) } 6 / 85 \\
\text { (3) } 3 / 82\end{array}$ & $\begin{array}{l}\text { (1) } 2.03 \\
\text { (3) } 1.41\end{array}$ & no data \\
\hline Herbertson 1994 & $\begin{array}{l}\text { (1) Diclofenac K } 50 \mathrm{mg}, \mathrm{n}= \\
52 \\
\text { (2) Diclofenac K } 100 \mathrm{mg}, \mathrm{n}= \\
52 \\
\text { (3) Aspirin } 650 \mathrm{mg}, \mathrm{n}=53 \\
\text { (4) Placebo, } \mathrm{n}=52\end{array}$ & $\begin{array}{l}\text { TOTPAR 6: } \\
\text { (1) } 12.1 \\
\text { (2) } 12.2 \\
\text { (4) } 3.7\end{array}$ & $\begin{array}{l}\text { (1) } 29 / 52 \\
\text { (2) } 29 / 52 \\
\text { (4) } 5 / 52\end{array}$ & $\begin{array}{l}\text { at } 8 \text { hours: } \\
\text { (1) } 28 / 52 \\
\text { (2) } 25 / 52 \\
\text { (4) } 6 / 52\end{array}$ & $\begin{array}{l}\text { (1) } 5.6 \\
\text { (2) } 6.1 \\
\text { (4) } 1.5\end{array}$ & $\begin{array}{l}\text { at } 6 \text { hours: } \\
\text { (1) } 50 \\
\text { (2) } 54 \\
\text { (4) } 82\end{array}$ \\
\hline Hersh 2004 & $\begin{array}{l}\text { (1) Diclofenac K } 25 \mathrm{mg}, \mathrm{n}= \\
63 \\
\text { (2) Diclofenac K } 50 \mathrm{mg}, \mathrm{n}= \\
68 \\
\text { (3) Diclofenac K } 100 \mathrm{mg}, \mathrm{n}= \\
66 \\
\text { (4) Placebo, } \mathrm{n}=68\end{array}$ & $\begin{array}{l}\text { TOTPAR 6: } \\
\text { (1) } 11.68 \\
\text { (2) } 13.86 \\
\text { (3) } 16.16 \\
\text { (4) } 4.99\end{array}$ & $\begin{array}{l}\text { (1) } 43 / 63 \\
\text { (2) } 44 / 68 \\
\text { (3) } 52 / 66 \\
\text { (4) } 11 / 68\end{array}$ & no usable data & $\begin{array}{l}\text { (1) } 5.83 \\
\text { (2) }>6 \\
\text { (3) }>6 \\
\text { (4) } 1.67\end{array}$ & $\begin{array}{l}\text { at } 6 \text { hours: } \\
\text { (1) } 51 \\
\text { (2) } 37 \\
\text { (3) } 32 \\
\text { (4) } 79\end{array}$ \\
\hline Hofele 2006 & $\begin{array}{l}\text { (1) Diclofenac K sachet } 50 \\
\mathrm{mg}, \mathrm{n}=74 \\
\text { (2) Diclofenac K tablet } 50 \mathrm{mg} \text {, } \\
\mathrm{n}=71 \\
\text { (3) Placebo, } \mathrm{n}=39\end{array}$ & $\begin{array}{l}\text { TOTPAR 6: } \\
\text { (1) } 15.5 \\
\text { (2) } 14.1 \\
\text { (3) } 7.2\end{array}$ & $\begin{array}{l}\text { (1) } 55 / 74 \\
\text { (2) } 47 / 71 \\
\text { (3) } 11 / 39\end{array}$ & no usable data & $\begin{array}{l}\text { Kaplan-Meier } \\
\text { estimate Mean: } \\
\text { (1) } 8.7 \\
\text { (2) } 8.9 \\
\text { (3) } 4.5\end{array}$ & $\begin{array}{l}\text { at } 8 \text { hours: } \\
\text { 1) } 37 \\
\text { (2) } 37 \\
\text { (3) } 72\end{array}$ \\
\hline Kubitzek 2003 & $\begin{array}{l}\text { (1) Diclofenac K } 25 \mathrm{mg}, \mathrm{n}= \\
83 \\
\text { (2) Paracetamol } 1000 \mathrm{mg}, \mathrm{n}= \\
78 \\
\text { (3) Placebo, } \mathrm{n}=84\end{array}$ & $\begin{array}{l}\text { TOTPAR 6: } \\
\text { values not } \\
\text { given }\end{array}$ & $\begin{array}{l}\text { (1) } 42 / 83 \\
\text { (3) } 7 / 84\end{array}$ & $\begin{array}{l}\text { at } 6 \text { hours: } \\
\text { (1) } 25 / 83 \\
\text { (3) } 1 / 84\end{array}$ & $\begin{array}{l}\text { (1) } 3.94 \\
\text { (3) } 1.47\end{array}$ & $\begin{array}{l}\text { at } 6 \text { hours: } \\
\text { (1) } 77 \\
\text { (3) } 89\end{array}$ \\
\hline Mehlisch 1994 & $\begin{array}{l}\text { (1) Diclofenac K } 50 \mathrm{mg}, \mathrm{n}= \\
53 \\
\text { (2) Diclofenac K } 100 \mathrm{mg}, \mathrm{n}= \\
52\end{array}$ & $\begin{array}{l}\text { TOTPAR 6: } \\
\text { (1) } 11.6 \\
\text { (2) } 14.3 \\
\text { (4) } 3.3\end{array}$ & $\begin{array}{l}\text { (1) } 28 / 53 \\
\text { (2) } 35 / 52 \\
\text { (4) } 4 / 52\end{array}$ & no usable data & $\begin{array}{l}\text { (1) } 5.9 \\
\text { (2) } 7.3 \\
\text { (4) } 1.8\end{array}$ & $\begin{array}{l}\text { at } 6 \text { hours: } \\
\text { (1) } 49 \\
\text { (2) } 30 \\
\text { (4) } 84\end{array}$ \\
\hline
\end{tabular}




\begin{tabular}{|c|c|c|c|c|c|c|}
\hline \multirow[b]{2}{*}{ Study ID } & \multirow[b]{2}{*}{ Treatment } & \multicolumn{2}{|l|}{ Analgesia } & \multirow[b]{2}{*}{$\begin{array}{l}\text { PGR: v good or } \\
\text { excellent }\end{array}$} & \multicolumn{2}{|c|}{ Rescue medication } \\
\hline & & PI or PR & $\begin{array}{l}\text { Number } \\
\text { with 50\% } \\
\text { PR }\end{array}$ & & $\begin{array}{l}\text { Median time to } \\
\text { use (hr) }\end{array}$ & $\%$ using \\
\hline & $\begin{array}{l}\text { (3) Aspirin } 650 \mathrm{mg}, \mathrm{n}=51 \\
\text { (4) Placebo, } \mathrm{n}=52\end{array}$ & & & & & \\
\hline Nelson 1994 & $\begin{array}{l}\text { (1) Diclofenac K } 25 \mathrm{mg}, \mathrm{n}= \\
50 \\
\text { (2) Diclofenac K } 50 \mathrm{mg}, \mathrm{n}= \\
50 \\
\text { (3) Diclofenac K } 100 \mathrm{mg}, \mathrm{n}= \\
50 \\
\text { (4) Aspirin } 650 \mathrm{mg}, \mathrm{n}=50 \\
\text { (5) Placebo, } \mathrm{n}=50\end{array}$ & $\begin{array}{l}\text { TOTPAR 6: } \\
\text { (1) } 10.5 \\
\text { (2) } 12.2 \\
\text { (3) } 14.8 \\
\text { (5) } 3.6\end{array}$ & $\begin{array}{l}\text { (1) } 23 / 50 \\
\text { (2) } 28 / 50 \\
\text { (3) } 35 / 50 \\
\text { (5) } 4 / 50\end{array}$ & no data & $\begin{array}{l}\text { (1) } 5.3 \\
\text { (2) }>8 \\
\text { (3) }>8 \\
\text { (5) } 2.8\end{array}$ & $\begin{array}{l}\text { at } 6 \text { hours: } \\
\text { (1) } 57 \\
\text { (2) } 39 \\
\text { (3) } 32 \\
\text { (5) } 65\end{array}$ \\
\hline Olson 1997 & $\begin{array}{l}\text { (1) Diclofenac K } 25 \mathrm{mg}, \mathrm{n}= \\
52 \\
\text { (2) Diclofenac K } 50 \mathrm{mg}, \mathrm{n}= \\
50 \\
\text { (3) Diclofenac K } 100 \mathrm{mg}, \mathrm{n}= \\
51 \\
\text { (4) Aspirin } 650 \mathrm{mg}, \mathrm{n}=50 \\
\text { (5) Placebo, n = 52 }\end{array}$ & $\begin{array}{l}\text { TOTPAR 4: } \\
\text { (1) } 8.9 \\
\text { (2) } 9.5 \\
\text { (3) } 10.1 \\
\text { (5) } 4.9\end{array}$ & $\begin{array}{l}\text { (1) } 32 / 52 \\
\text { (2) } 34 / 50 \\
\text { (3) } 37 / 51 \\
\text { (5) } 15 / 52\end{array}$ & no usable data & $\begin{array}{l}\text { (1) } 5.4 \\
\text { (2) } 3.0 \\
\text { (3) } 5.4 \\
\text { (5) } 2.3\end{array}$ & $\begin{array}{l}\text { at } 6 \text { hours: } \\
\text { (1) } 4 \\
\text { (2) } 2 \\
\text { (3) } 0 \\
\text { (5) } 37\end{array}$ \\
\hline Torres 2004 & $\begin{array}{l}\text { (1) Diclofenac SR } 75 \mathrm{mg}, \mathrm{n}= \\
68 \\
\text { (2) Valdecoxib } 20 \mathrm{mg}, \mathrm{n}=68 \\
\text { (3) Valdecoxib } 40 \mathrm{mg}, \mathrm{n}=69 \\
\text { (4) Placebo, } \mathrm{n}=67\end{array}$ & $\begin{array}{l}\text { SPID } 6 \text { could } \\
\text { not be } \\
\text { calculated } \\
\text { because } \\
\text { baseline pain } \\
\text { was not } \\
\text { reported }\end{array}$ & no data & no usable & $\begin{array}{l}\text { data no usable } \\
\text { data }\end{array}$ & $\begin{array}{l}\text { at } 12 \text { hours: } \\
\text { (1) } 39 \\
\text { (4) } 52\end{array}$ \\
\hline Zuniga 2004 & $\begin{array}{l}\text { (1) Diclofenac K } 100 \mathrm{mg}, \mathrm{n}= \\
31 \\
\text { (2) Diclofenac Na softgel } 100 \\
\text { mg, } \mathrm{n}=29 \\
\text { (3) Placebo, } \mathrm{n}=15\end{array}$ & $\begin{array}{l}\text { TOTPAR 6: } \\
\text { (1) } 9.7 \\
\text { (2) } 12.2 \\
\text { (3) } 0.91\end{array}$ & $\begin{array}{l}\text { (1) } 13 / 31 \\
\text { (2) } 16 / 29 \\
\text { (3) } 0 / 15\end{array}$ & $\begin{array}{l}\text { at } 6 \text { hours: } \\
\text { (1) } 14 / 31 \\
\text { (2) } 21 / 29 \\
\text { (3) } 1 / 15\end{array}$ & $\begin{array}{l}\text { Mean: } \\
\text { (1) } 4.5 \\
\text { (2) } 5 \\
\text { (3) } 1.1\end{array}$ & $\begin{array}{l}\text { at } 6 \text { hours: } \\
\text { (1) } 71 \\
\text { (2) } 69 \\
\text { (3) } 100\end{array}$ \\
\hline
\end{tabular}




\section{Table 2}

Summary of outcomes: adverse events and withdrawals

\begin{tabular}{|c|c|c|c|c|c|}
\hline & & Adverse events & & Withdrawals & \\
\hline Study ID & Treatment & Any & Serious & Adverse event & Other \\
\hline Ahlstrom 1993 & $\begin{array}{l}\text { (1)Diclofenac (soluble) } 50 \mathrm{mg}, \mathrm{n}= \\
35 \\
\text { (2) Ibuprofen (tablets) } 400 \mathrm{mg}, \mathrm{n}= \\
32 \\
\text { (3) Placebo, } \mathrm{n}=30\end{array}$ & $\begin{array}{l}\text { (1) } 6 / 35 \\
\text { (3) } 2 / 30 \\
\text { considered } \\
\text { treatment-related in } \\
1 \text { diclofenac and } 1 \\
\text { ibuprofen patient }\end{array}$ & None reported & None & $\begin{array}{l}30 \text { exclusions: } \\
\text { various protocol } \\
\text { violations }\end{array}$ \\
\hline Bakshi 1992 & $\begin{array}{l}\text { (1) Diclofenac K } 50 \mathrm{mg}, \mathrm{n}=51 \\
\text { (2) Diclofenac } \mathrm{Na} \text { (enteric coated) } 50 \\
\mathrm{mg}, \mathrm{n}=54 \\
\text { (3) Placebo, } \mathrm{n}=46\end{array}$ & $\begin{array}{l}\text { Possibly or } \\
\text { probably treatment- } \\
\text { related } \\
\text { (1) } 3 / 51 \\
\text { (2) } 1 / 54 \\
\text { (3) } 3 / 46\end{array}$ & None & None & $\begin{array}{l}29 \text { exclusions: } 26 \\
\text { did not need } \\
\text { medication, } 3 \text { lost to } \\
\text { followup }\end{array}$ \\
\hline Bakshi 1994 & $\begin{array}{l}\text { (1)Diclofenac (soluble) } 50 \mathrm{mg}, \mathrm{n}= \\
83 \\
\text { (2) Ibuprofen } 400 \mathrm{mg}, \mathrm{n}=80 \\
\text { (3) Placebo, } \mathrm{n}=82\end{array}$ & $\begin{array}{l}\text { (1) } 4 / 83 \\
\text { (3) } 5 / 82\end{array}$ & None reported & None & $\begin{array}{l}12 \text { exclusions: } \\
\text { various protocol } \\
\text { violations }\end{array}$ \\
\hline Chang 2002 & $\begin{array}{l}\text { (1) Diclofenac } \mathrm{Na} \text { (enteric coated) } 50 \\
\mathrm{mg}, \mathrm{n}=121 \\
\text { (2) Rofecoxib } 50 \mathrm{mg}, \mathrm{n}=121 \\
\text { (3) Placebo, } \mathrm{n}=63\end{array}$ & No single dose data & $\begin{array}{l}\text { No single dose } \\
\text { data }\end{array}$ & $\begin{array}{l}\text { at } 36 \text { hours: } \\
\text { (3) } 1 / 63 \\
\text { (asthma flare) }\end{array}$ & None \\
\hline Cooper 1996 & $\begin{array}{l}\text { (1) Diclofenac Na } 50 \mathrm{mg}, \mathrm{n}=18 \\
\text { (2) Misoprostol } 200 \mu \mathrm{g}, \mathrm{n}=21 \\
\text { (3) Diclofenac Na }+ \text { misoprostol } 50 \\
\mathrm{mg} / 200 \mu \mathrm{g}, \mathrm{n}=20 \\
\text { (4) Placebo, } \mathrm{n}=11\end{array}$ & $\begin{array}{l}\text { No usable data. All } \\
\text { AEs were transient } \\
\text { and mild, and } \\
\text { considered normal } \\
\text { sequale of surgical } \\
\text { procedure and } \\
\text { probably unrelated } \\
\text { to study drug }\end{array}$ & None & & \\
\hline Desjardins 2004 & $\begin{array}{l}\text { (1) Diclofenac Na } 100 \mathrm{mg}, \mathrm{n}=85 \\
\text { (2) Rofecoxib } 50 \mathrm{mg}, \mathrm{n}=85 \\
\text { (3) Placebo, } \mathrm{n}=82\end{array}$ & $\begin{array}{l}\text { at } 24 \text { hours: } \\
\text { (1) } 38 / 85 \\
\text { (3) } 41 / 82\end{array}$ & None & $\begin{array}{l}\text { (1) } 1 / 85 \\
\text { (3) } 3 / 82\end{array}$ & None reported \\
\hline Herbertson 1994 & $\begin{array}{l}\text { (1) Diclofenac K } 50 \mathrm{mg}, \mathrm{n}=52 \\
\text { (2) Diclofenac K } 100 \mathrm{mg}, \mathrm{n}=52 \\
\text { (3) Aspirin } 650 \mathrm{mg}, \mathrm{n}=53 \\
\text { (4) Placebo, } \mathrm{n}=52\end{array}$ & $\begin{array}{l}\text { (1) } 6 / 54 \\
\text { (2) } 6 / 55 \\
\text { (4) } 2 / 54\end{array}$ & None & 8 in total & $\begin{array}{l}\text { In total, } 8 \\
\text { participants did not } \\
\text { contribute to any } \\
\text { efficacy analysis, } 23 \\
\text { did not contribute to } \\
\text { reported TOTPAR } 8\end{array}$ \\
\hline Hersh 2004 & $\begin{array}{l}\text { (1) Diclofenac K } 25 \mathrm{mg}, \mathrm{n}=63 \\
\text { (2) Diclofenac K } 50 \mathrm{mg}, \mathrm{n}=68 \\
\text { (3) Diclofenac K } 100 \mathrm{mg}, \mathrm{n}=66 \\
\text { (4) Placebo, } \mathrm{n}=68\end{array}$ & $\begin{array}{l}\text { (1) } 8 / 63 \\
\text { (2) } 8 / 68 \\
\text { (3) } 7 / 66 \\
\text { (4) } 9 / 68\end{array}$ & None reported & None & $\begin{array}{l}1 \text { placebo participant } \\
\text { unwilling to } \\
\text { continue }\end{array}$ \\
\hline Hofele 2006 & $\begin{array}{l}\text { (1) Diclofenac K sachet } 50 \mathrm{mg}, \mathrm{n}= \\
74 \\
\text { (2) Diclofenac K tablet } 50 \mathrm{mg}, \mathrm{n}=71 \\
\text { (3) Placebo, } \mathrm{n}=39\end{array}$ & $\begin{array}{l}\text { at } 8 \text { hours: } \\
\text { (1) } 2 / 74 \\
\text { (2) } 2 / 71 \\
\text { (3) } 2 / 39\end{array}$ & None & None & $\begin{array}{l}5 \text { exclusions for } \\
\text { protocol violations: } \\
2 \text { diclofenac sachet, } \\
1 \text { diclofenac tablet, } 1 \\
\text { placebo }\end{array}$ \\
\hline Kubitzek 2003 & $\begin{array}{l}\text { (1) Diclofenac K } 25 \mathrm{mg}, \mathrm{n}=83 \\
\text { (2) Paracetamol } 1000 \mathrm{mg}, \mathrm{n}=78 \\
\text { (3) Placebo, } \mathrm{n}=84\end{array}$ & $\begin{array}{l}\text { at } 48 \mathrm{hrs:} \\
\text { (1) } 6 / 83 \\
\text { (3) } 2 / 84\end{array}$ & None & None & $\begin{array}{l}1 \text { placebo participant } \\
\text { excluded for } \\
\text { protocol violation }\end{array}$ \\
\hline Mehlisch 1994 & $\begin{array}{l}\text { 1) Diclofenac K } 50 \mathrm{mg}, \mathrm{n}=53 \\
\text { (2) Diclofenac K } 100 \mathrm{mg}, \mathrm{n}=52 \\
\text { (3) Aspirin } 650 \mathrm{mg}, \mathrm{n}=51 \\
\text { (4) Placebo, } \mathrm{n}=52\end{array}$ & $\begin{array}{l}\text { at } 7 \text { days: } \\
\text { (1) } 5 / 53 \\
\text { (2) } 8 / 52 \\
\text { (4) } 4 / 52\end{array}$ & None & None & None reported \\
\hline Nelson 1994 & $\begin{array}{l}\text { (1) Diclofenac K } 25 \mathrm{mg}, \mathrm{n}=50 \\
\text { (2) Diclofenac K } 50 \mathrm{mg}, \mathrm{n}=50 \\
\text { (3) Diclofenac K } 100 \mathrm{mg}, \mathrm{n}=50 \\
\text { (4) Aspirin } 650 \mathrm{mg}, \mathrm{n}=50\end{array}$ & $\begin{array}{l}\text { at } 8 \text { hours: } \\
\text { (1) } 5 / 51 \\
\text { (2) } 4 / 51 \\
\text { (3) } 4 / 51\end{array}$ & None reported & None & $\begin{array}{l}1 \text { participant } \\
\text { excluded from } \\
\text { safety analysis, } 3 \\
\text { excluded from any }\end{array}$ \\
\hline
\end{tabular}

Cochrane Database Syst Rev. Author manuscript; available in PMC 2014 September 15. 


\begin{tabular}{|c|c|c|c|c|c|}
\hline & & Adverse events & & Withdrawals & \\
\hline \multirow[t]{2}{*}{ Study ID } & Treatment & Any & Serious & Adverse event & Other \\
\hline & (5) Placebo, $\mathrm{n}=50$ & (5) $6 / 51$ & & & $\begin{array}{l}\text { efficacy analysis, } 7 \\
\text { excluded from } 8 \\
\text { hour efficacy } \\
\text { analysis }\end{array}$ \\
\hline Olson 1997 & $\begin{array}{l}\text { (1) Diclofenac K } 25 \mathrm{mg}, \mathrm{n}=52 \\
\text { (2) Diclofenac K } 50 \mathrm{mg}, \mathrm{n}=50 \\
\text { (3) Diclofenac K } 100 \mathrm{mg}, \mathrm{n}=51 \\
\text { (4) Aspirin } 650 \mathrm{mg}, \mathrm{n}=50 \\
\text { (5) Placebo, } \mathrm{n}=52\end{array}$ & $\begin{array}{l}\text { at } 8 \text { hours: } \\
\text { (1) } 1 / 52 \\
\text { (2) } 0 / 50 \\
\text { (3) } 1 / 51 \\
\text { (5) } 1 / 52\end{array}$ & None & None & None \\
\hline Torres 2004 & $\begin{array}{l}\text { (1)Diclofenac SR75 mg, } n=68 \\
\text { (2) Valdecoxib } 20 \mathrm{mg}, \mathrm{n}=68 \\
\text { (3) Valdecoxib } 40 \mathrm{mg}, \mathrm{n}=69 \\
\text { (4) Placebo, } \mathrm{n}=67\end{array}$ & $\begin{array}{l}\text { at } 12 \text { hours: } \\
\text { (1) } 14 / 65 \\
\text { (4) } 17 / 67\end{array}$ & None reported & No usable data & No usable data \\
\hline Zuniga 2004 & $\begin{array}{l}\text { (1) Diclofenac K } 100 \mathrm{mg}, \mathrm{n}=31 \\
\text { (2) Diclofenac Na softgel } 100 \mathrm{mg}, \mathrm{n} \\
=29 \\
\text { (3) Placebo, } \mathrm{n}=15\end{array}$ & $\begin{array}{l}\text { at } 24 \text { hours: } \\
\text { (1) } 5 / 31 \\
\text { (2) } 5 / 29 \\
\text { (3) } 1 / 15 \\
\text { most occurred after } \\
\text { rescue medication }\end{array}$ & None & None & $\begin{array}{l}1 \text { participant } \\
\text { excluded due to } \\
\text { protocol violation }\end{array}$ \\
\hline
\end{tabular}

